\begin{tabular}{|c|c|c|c|c|c|c|c|c|}
\hline \multicolumn{3}{|c|}{$\begin{array}{l}\text { 2. To: (Receiving Organization) } \\
\text { DISTRIBUTION }\end{array}$} & \multicolumn{3}{|c|}{ 3. From: (Originating Organization) } & \multicolumn{3}{|c|}{ 4. Related EDT No.: } \\
\hline \multicolumn{3}{|c|}{$\begin{array}{l}\text { 5. Proj./Prog./Dept./Div.: } \\
\text { Work Management Implementation }\end{array}$} & \multicolumn{3}{|c|}{$\begin{array}{l}\text { 6. Design Authority/ Design Agent/Cog. } \\
\text { Engr.: } \\
\text { C. E. Shipler }\end{array}$} & \multicolumn{3}{|c|}{$\begin{array}{r}\text { 7. Purchase Order No.: } \\
\qquad \text { N/A }\end{array}$} \\
\hline \multicolumn{6}{|c|}{ 8. Originator Remarks: } & \multicolumn{3}{|c|}{$\begin{array}{l}\text { 9. Equip./Component No:: } \\
\text { N/A }\end{array}$} \\
\hline \multicolumn{6}{|c|}{$\begin{array}{l}\text { Indus Passport Action Tracking issued at } \\
\text { Revision Tos } 12 / 18 / 99\end{array}$} & \multicolumn{3}{|c|}{$\begin{array}{l}\text { 10. System/Bldg./Facility: } \\
\text { MO-252/200E }\end{array}$} \\
\hline \multirow{3}{*}{\multicolumn{3}{|c|}{ 11. Receiver Remarks: }} & Docu & 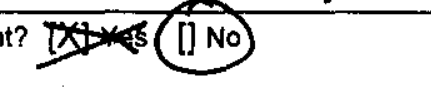 & & \multicolumn{3}{|c|}{$\begin{array}{l}\text { 12. Major Assm. DWg. No.. } \\
\text { N/A }\end{array}$} \\
\hline & & & & & & \multicolumn{3}{|c|}{$\begin{array}{l}\text { 13. PermitPermit Application No: } \\
\text { N/A }\end{array}$} \\
\hline & & & & & & \multicolumn{3}{|c|}{$\begin{array}{l}\text { 14. Required Response Date: } \\
\text { N/A }\end{array}$} \\
\hline 15. & & ATA TR & NSMIT & & (F) & (G) & $(H)$ & (I) \\
\hline $\begin{array}{l}\text { (A) } \\
\text { item } \\
\text { No. }\end{array}$ & (B) Document:Drawing No. & $\begin{array}{l}\text { (C) } \\
\text { Sheet } \\
\text { No. }\end{array}$ & $\begin{array}{l}\text { (D) } \\
\text { Rev. } \\
\text { No. }\end{array}$ & (E) Titie or Description of Data Transmitted & $\begin{array}{c}\text { Approval } \\
\text { Desig- } \\
\text { nator }\end{array}$ & $\begin{array}{l}\text { Reason for } \\
\text { Trans- } \\
\text { mittal }\end{array}$ & $\begin{array}{l}\text { Origi- } \\
\text { Nator } \\
\text { Dispo- } \\
\text { Sition }\end{array}$ & $\begin{array}{l}\text { Receiv- } \\
\text { Er } \\
\text { Dispo- } \\
\text { Sition }\end{array}$ \\
\hline 1 & RPP-5547 & N/A & 1 & $\begin{array}{l}\text { Work Flow Analysis Report } \\
\text { Action Tracking }\end{array}$ & $\mathrm{N} / \mathrm{A}$ & $\overline{1,2}$ & 2 & 2 \\
\hline & & & & & & & & \\
\hline & & & & & & & & \\
\hline & & & & & & & & \\
\hline & & & & & & & & \\
\hline & & & & & & & & \\
\hline
\end{tabular}

16.

KEY

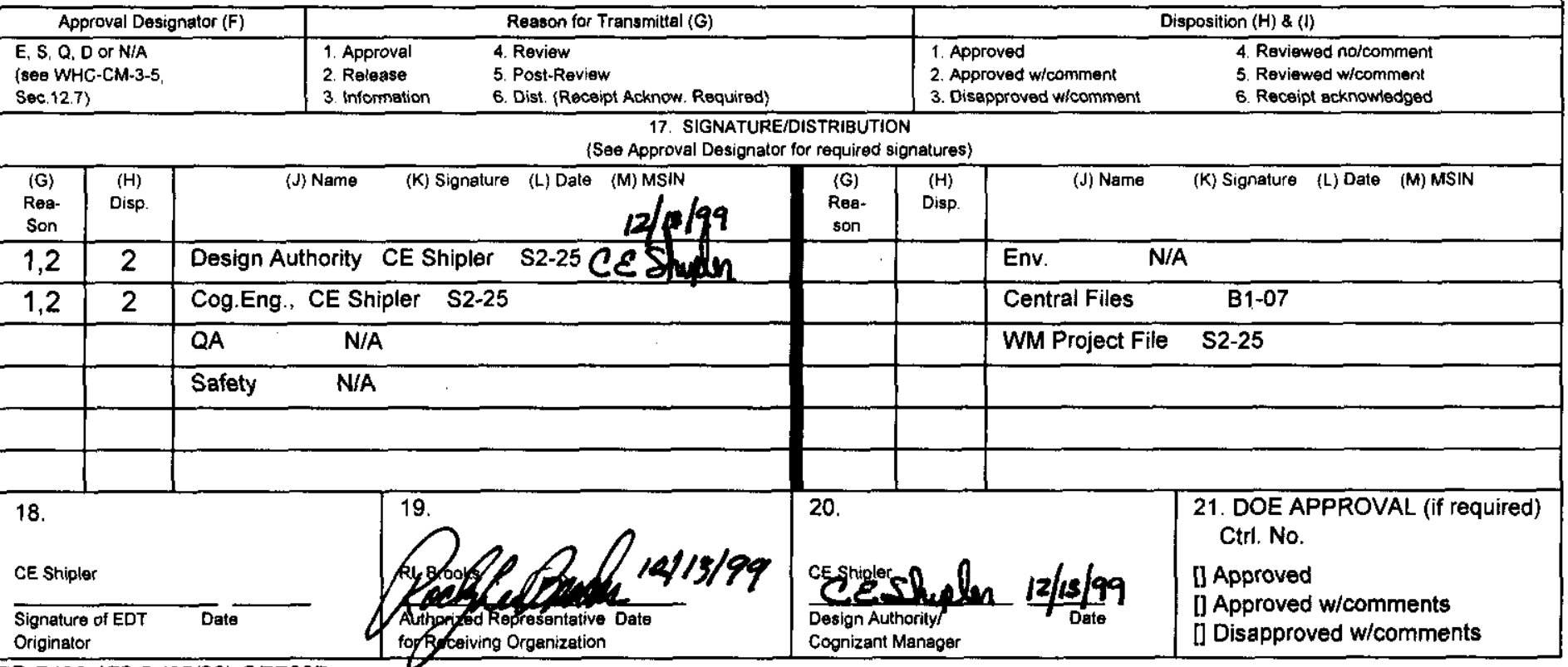

BD-7400-172-2 (05/96) GEF097 
DISTRIBUTION SHEET

\begin{tabular}{|c|c|c|c|c|c|}
\hline \multirow{2}{*}{$\begin{array}{l}\text { To } \\
\text { Production Control Management }\end{array}$} & \multirow{2}{*}{\multicolumn{3}{|c|}{$\begin{array}{l}\text { From } \\
\text { Information Resource Management }\end{array}$}} & \multicolumn{2}{|l|}{ Page 1 of 1} \\
\hline & & & & \multicolumn{2}{|c|}{ Date December 13, 1999} \\
\hline \multicolumn{4}{|l|}{ Project Title/Work Order } & \multicolumn{2}{|c|}{ EDT No. 628576} \\
\hline \multicolumn{4}{|c|}{ Work Flow Analysis Report for Action Tracking } & \multicolumn{2}{|l|}{ ECN No. N/A } \\
\hline Name & MSIN & $\begin{array}{c}\text { Text } \\
\text { With All } \\
\text { Attach. }\end{array}$ & $\begin{array}{l}\text { Text } \\
\text { Only }\end{array}$ & $\begin{array}{l}\text { Attach./ } \\
\text { Appendix } \\
\text { Only }\end{array}$ & $\begin{array}{c}\text { EDT/ECN } \\
\text { Only }\end{array}$ \\
\hline Central Files & BT -07 & $x$ & & & \\
\hline $\begin{array}{l}\text { L. C. Allison } \\
\text { W. D. Bancroft } \\
\text { R. L. Brooks } \\
\text { K. A. Crace } \\
\text { J. K. Hamilton } \\
\text { J. B. Jech } \\
\text { T. L. Jennings } \\
\text { D. L. Marquez } \\
\text { R. L. Nelson (2 Copies) } \\
\text { M. Petermann } \\
\text { C. E. Shipler } \\
\text { RL Reading Room }\end{array}$ & $\begin{array}{l}\text { R1-29 } \\
\text { S7-90 } \\
\text { S7-90 } \\
\text { H8-41 } \\
\text { R1-31 } \\
\text { S2-25 } \\
\text { R2-33 } \\
\text { H7-06 } \\
\text { H7-06 } \\
\text { H7-06 } \\
\text { S2-25 } \\
\text { H2-53 }\end{array}$ & $\begin{array}{l}x \\
x \\
x \\
x \\
x \\
x \\
x \\
x \\
x \\
\\
x \\
x\end{array}$ & $x$ & & \\
\hline
\end{tabular}




\title{
Work Flow Analysis Report
}

\section{Action Tracking}

\section{Petermann}

T. L. Jennings

Lockheed Martin Hanford Company, Richland, WA 99352

U.S. Department of Energy Contract DE-AC06-96RL13200

\author{
EDT/ECN: EDT 628576 \\ UC: 2030 \\ Org Code: 76000 \\ B\&R Code: EW02J123 \\ Charge Code: AJ10/CACN 109547/HMLM0371 \\ Total Pages: 43
}

Key Words: WFAR, Work Flow Analysis Report, Action Tracking

Abstract: The Work Flow Analysis Report will be used to facilitate the requirements for implementing the further deployment of the Action Tracking module of Passport. The report consists of workflow integration processes for Action Tracking. This document contains the workflow requirements for the Passport system prior to production release.

TRADEMARK DISCLAIMER. Reference herein to any specific commercial product, process, or service by trade name, trademark, manufacturer, or otherwise, does not necessarily constitute or imply its endorsement, recommendation, or favoring by the United States Government or any agency thereof or its contractors or subcontractors.

Printed in the United States of America. To obtain copies of this document, contact: Document Control Services, P.O. Box 950, Mailstop H6 $372-2420 ;$ Fax (509) 376-4989.
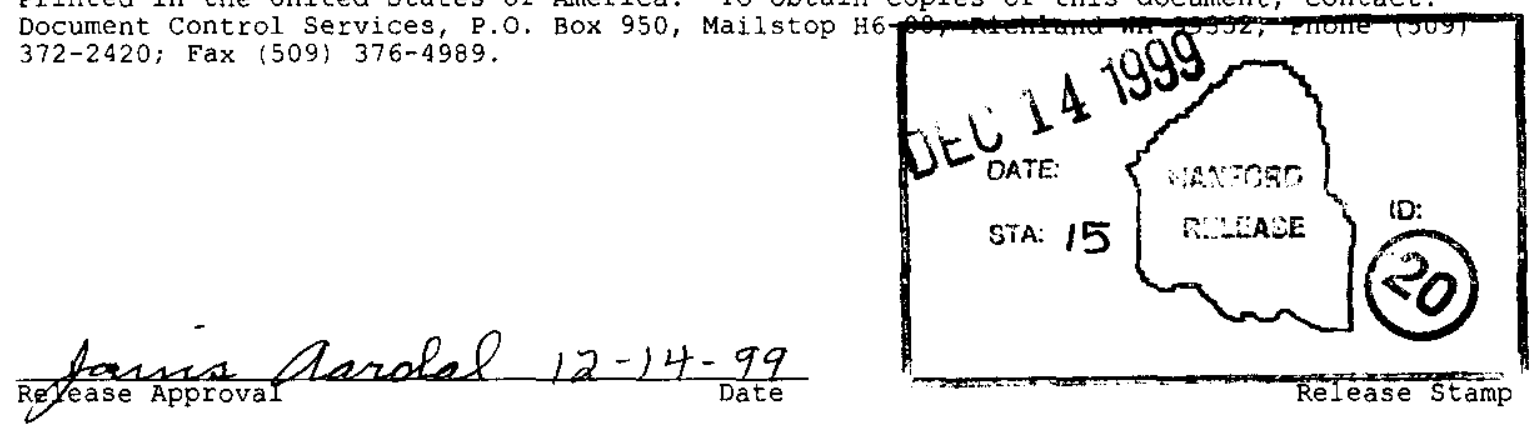

\section{Approved for Public Release}



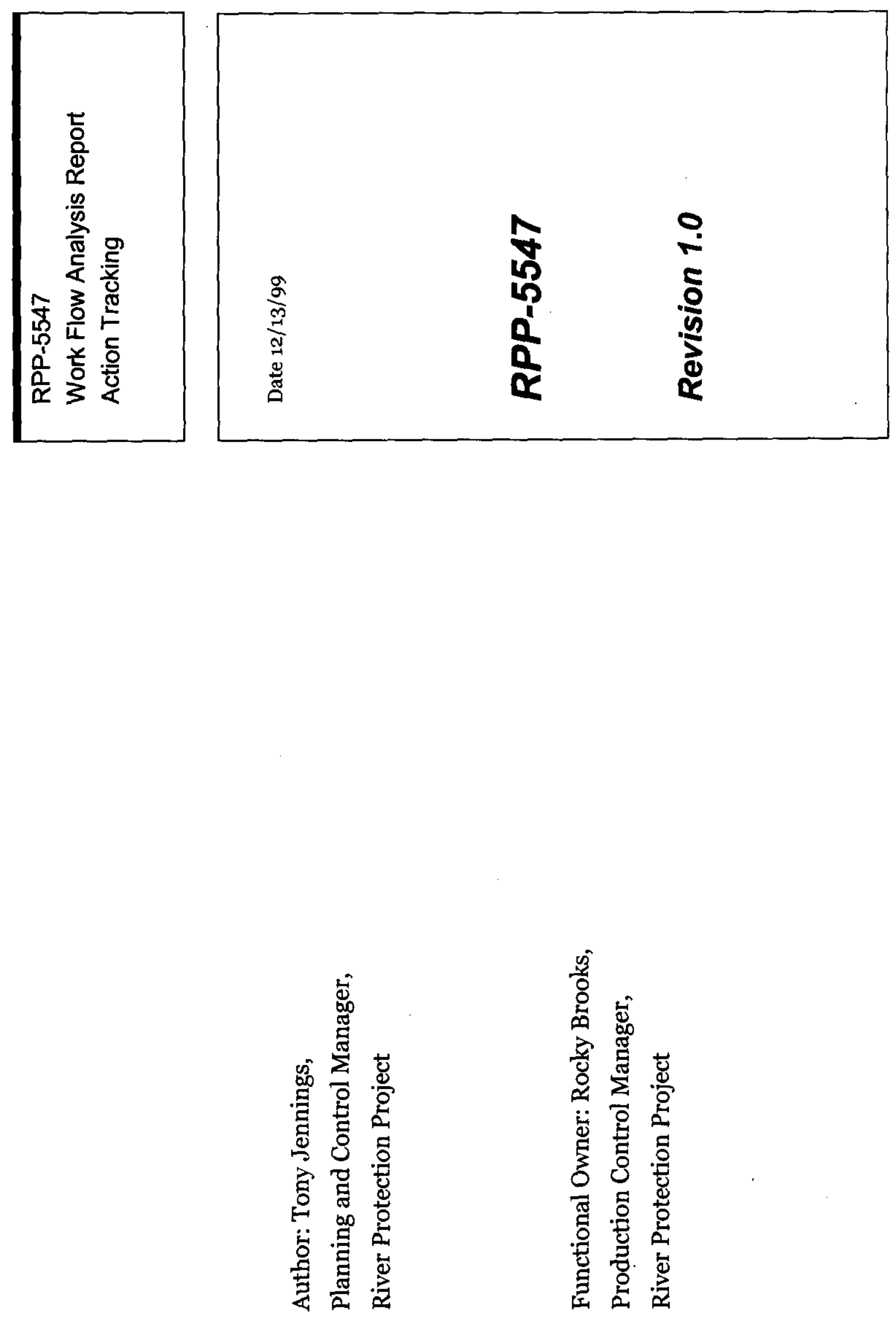


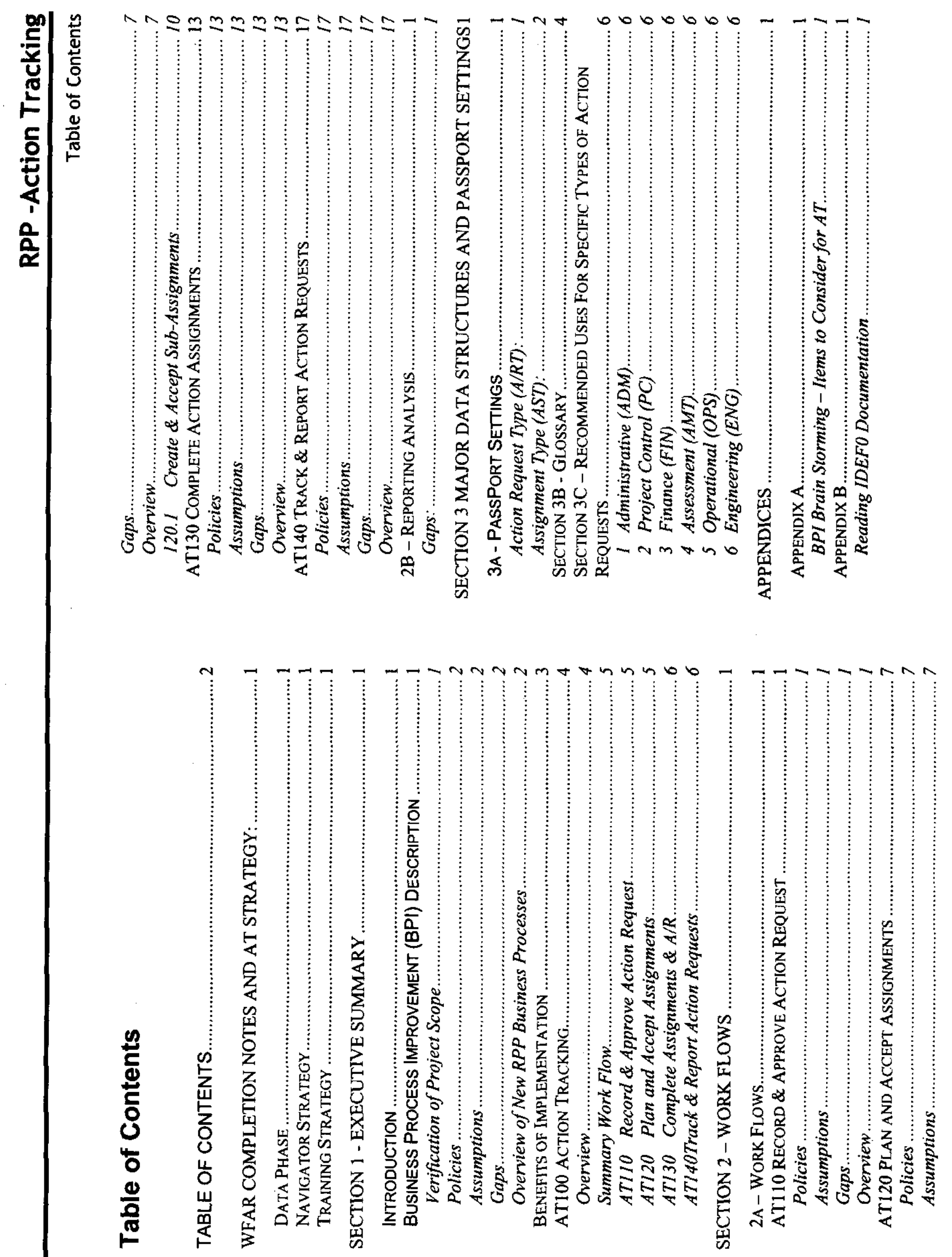




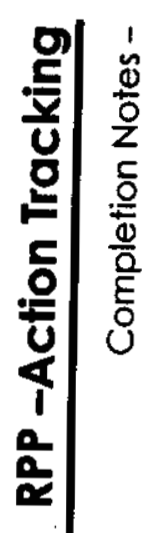

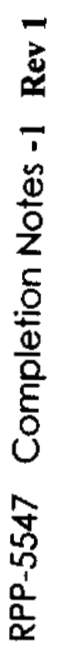
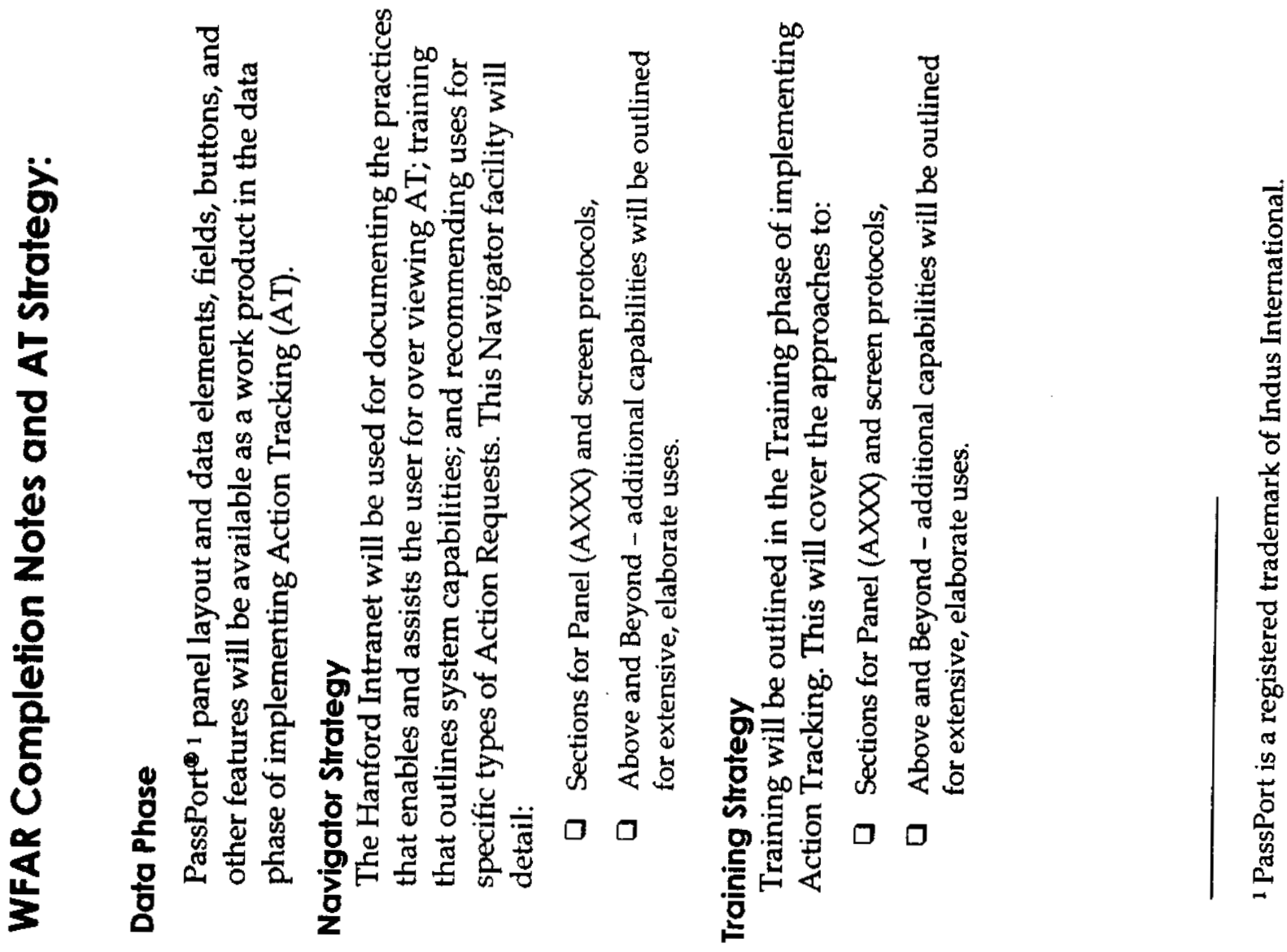


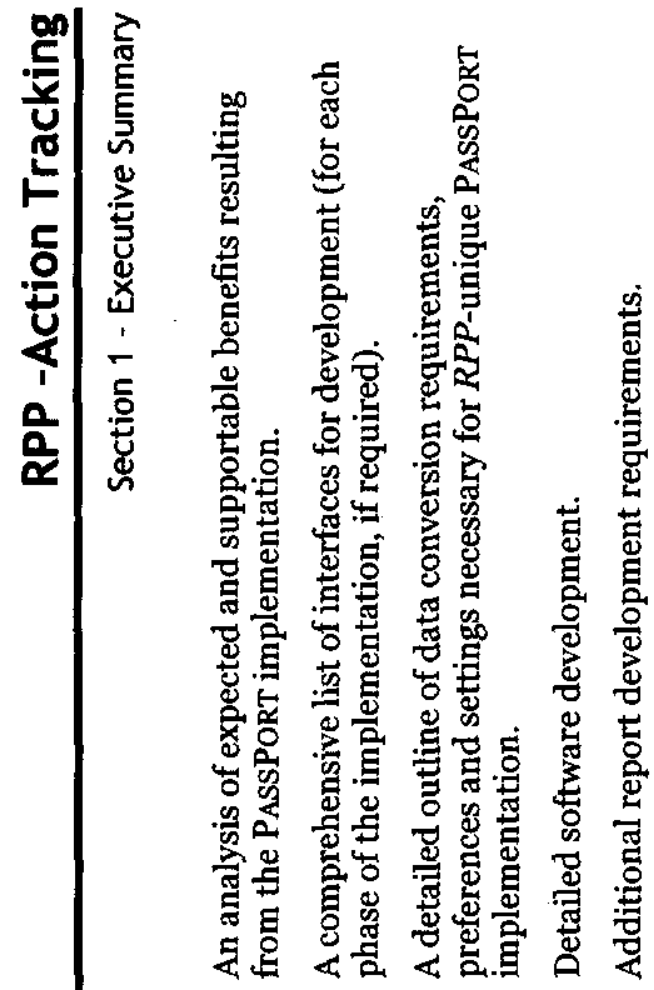

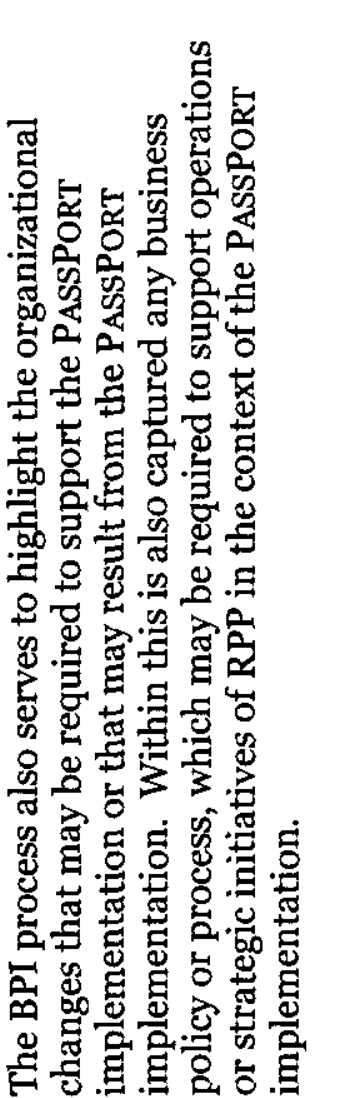

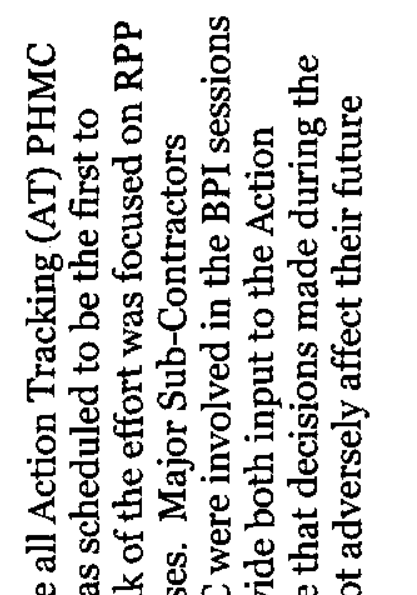

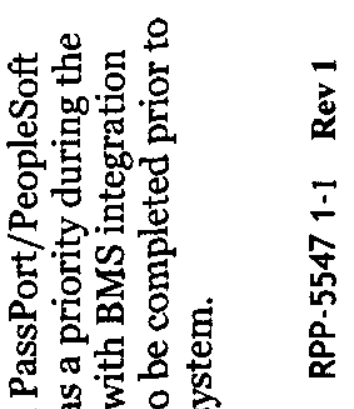

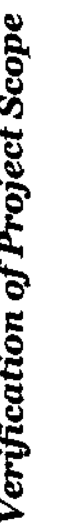

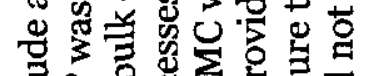

8 然

苛高覃

跣政

记

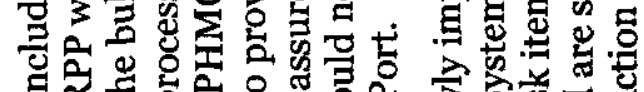

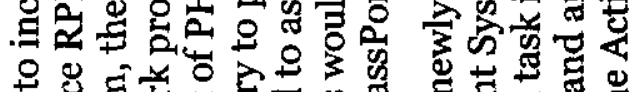
월렴

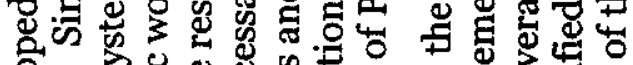

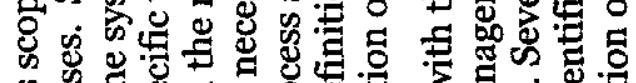

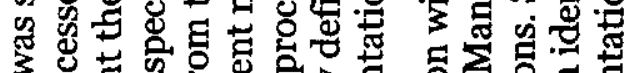

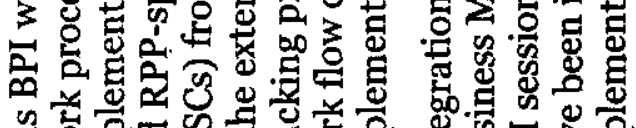

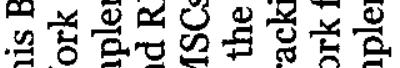

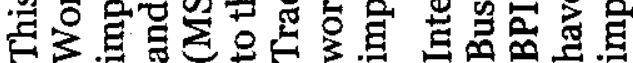

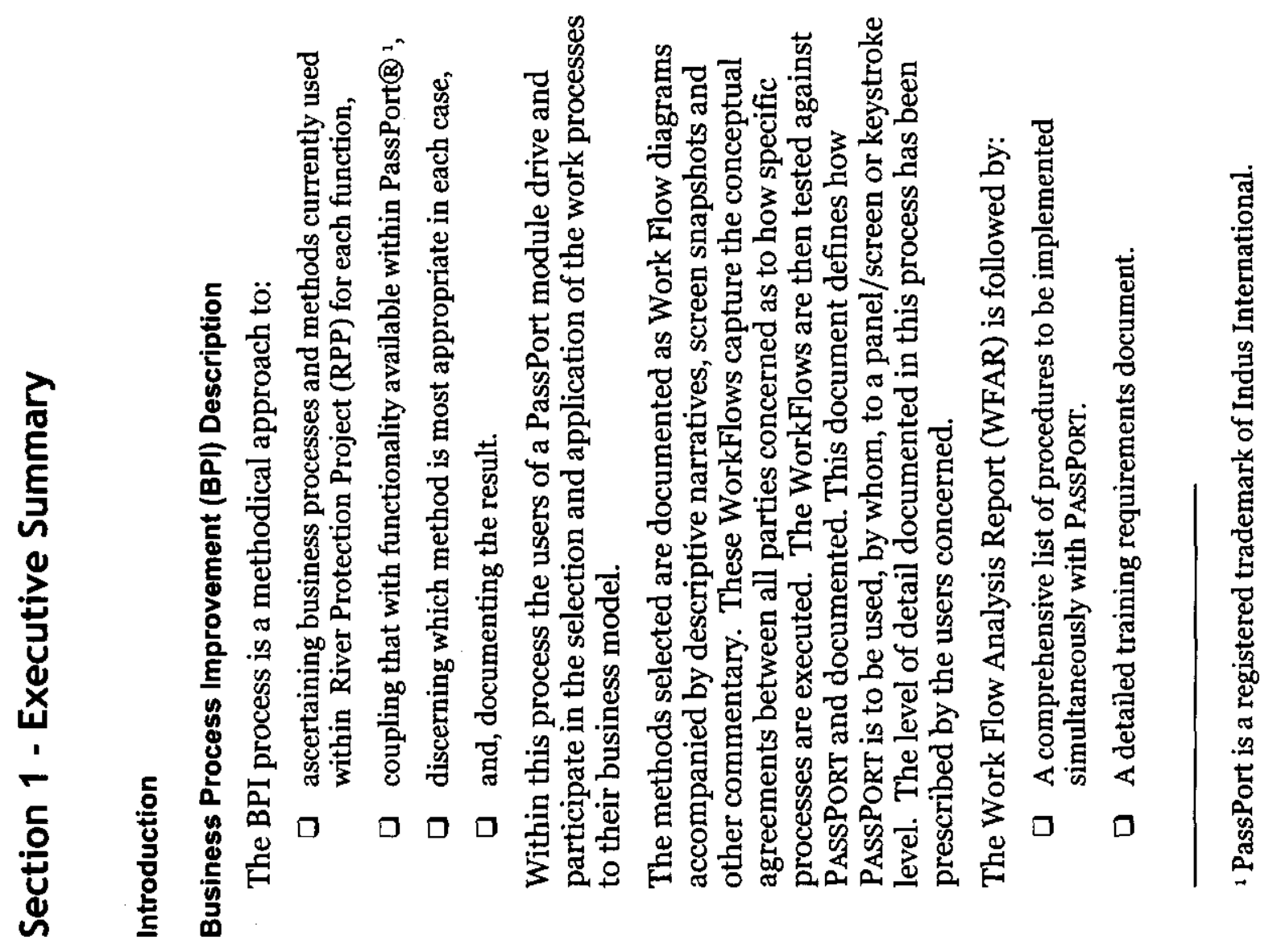



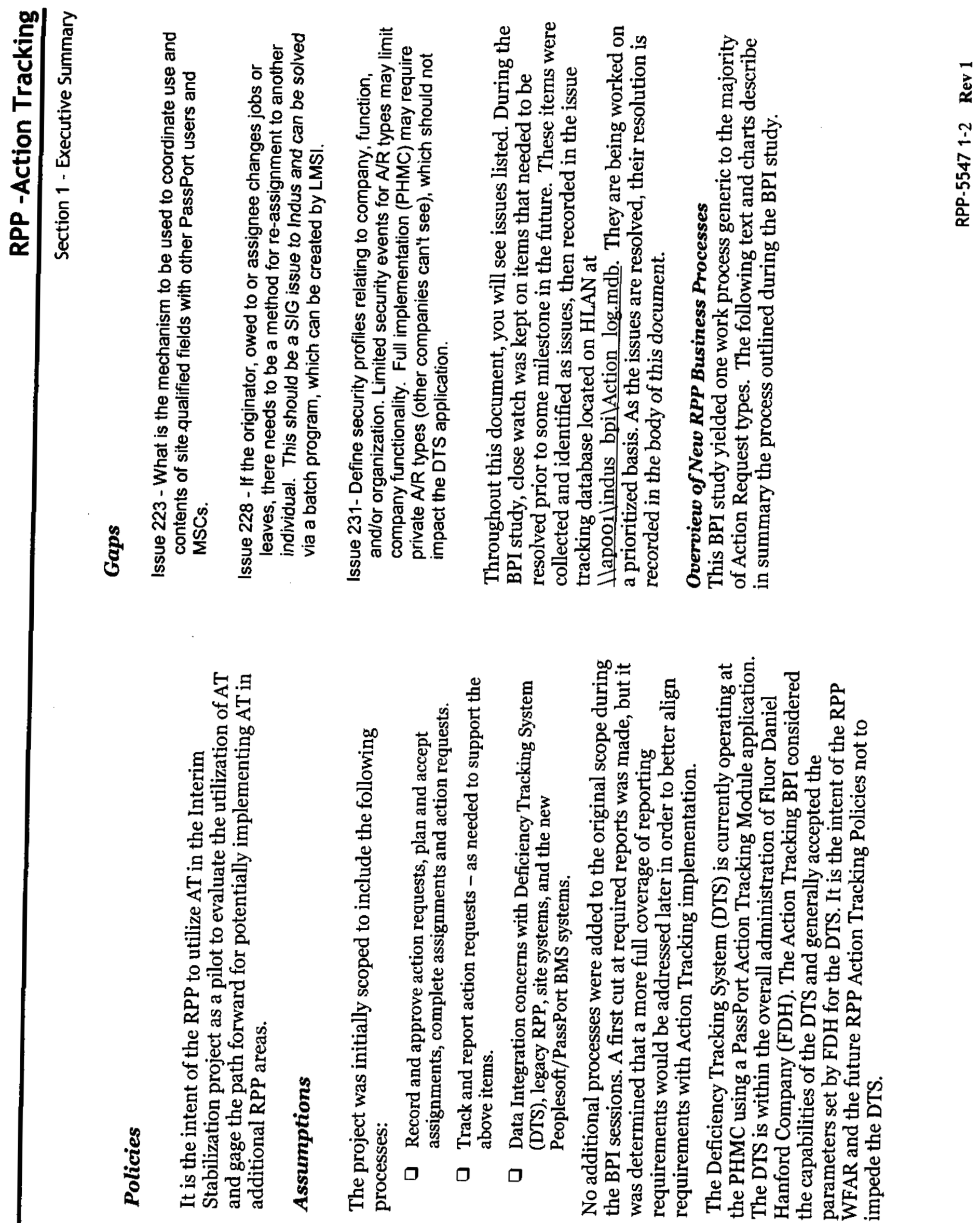


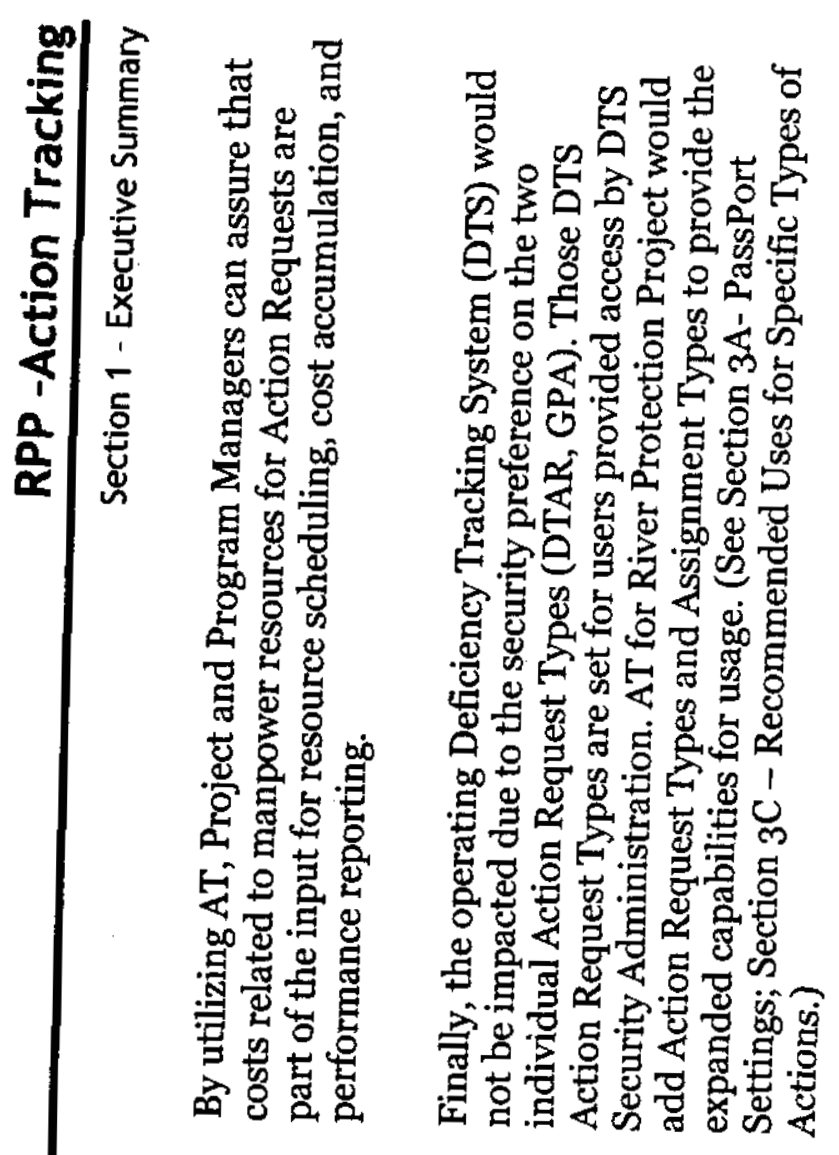

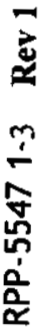

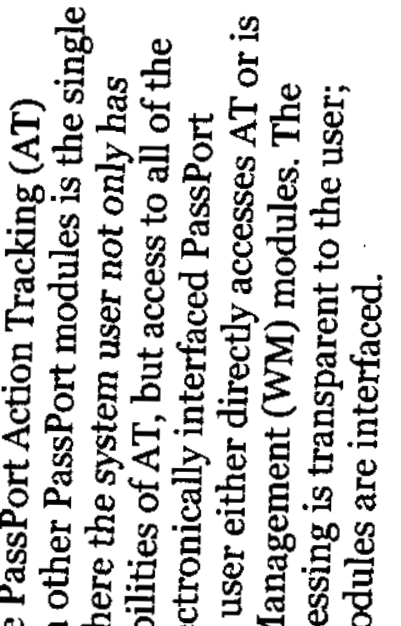

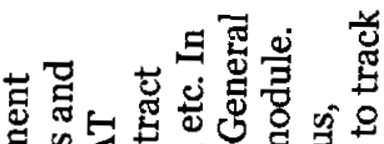

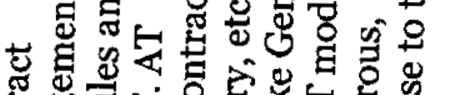

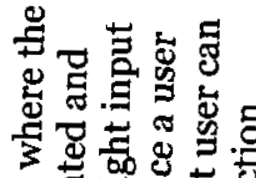

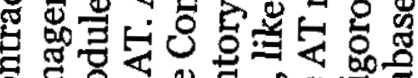

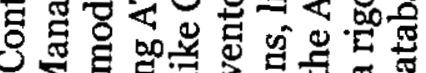

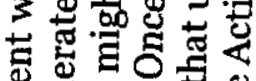

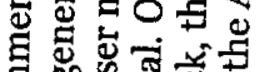

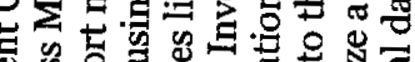

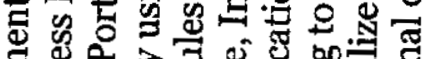

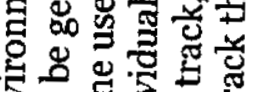

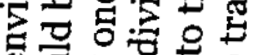

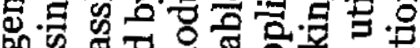

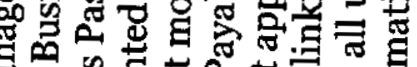

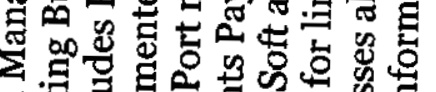

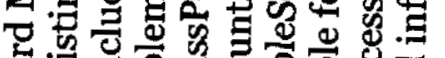

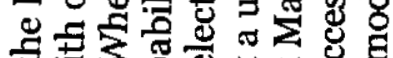

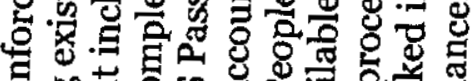

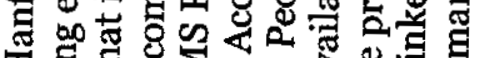
正.

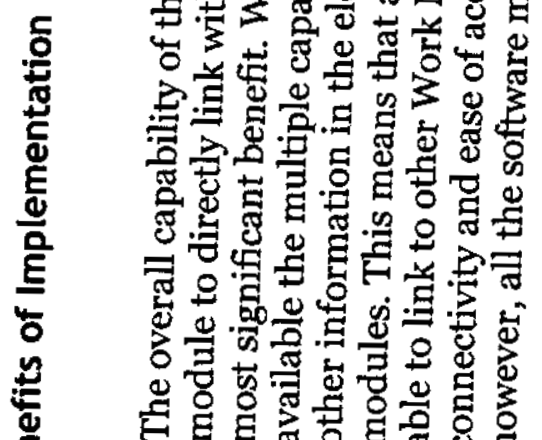

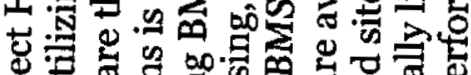

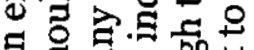

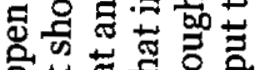

荡苛要

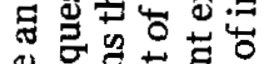

8 氙范范

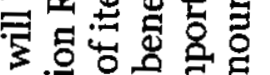

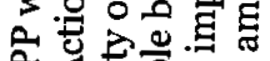

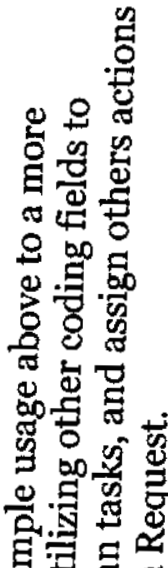

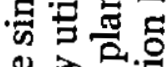

定定总

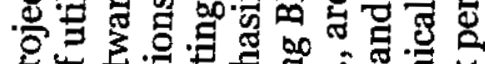

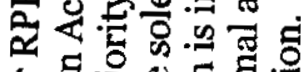

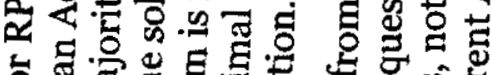
क O

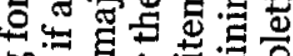

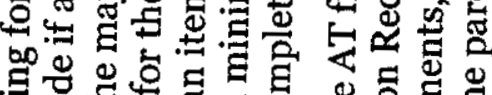

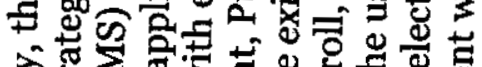

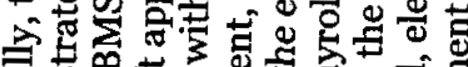

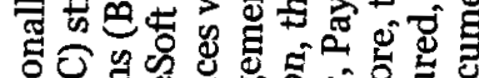

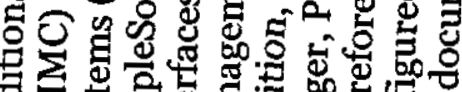

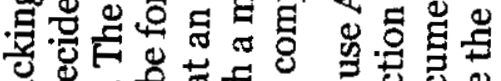

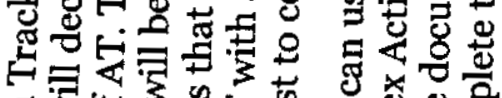

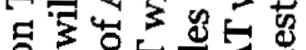
รึ 교 号它它志吉 当要

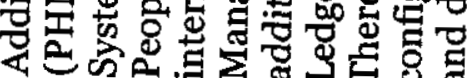

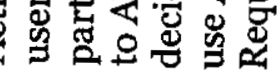
용 

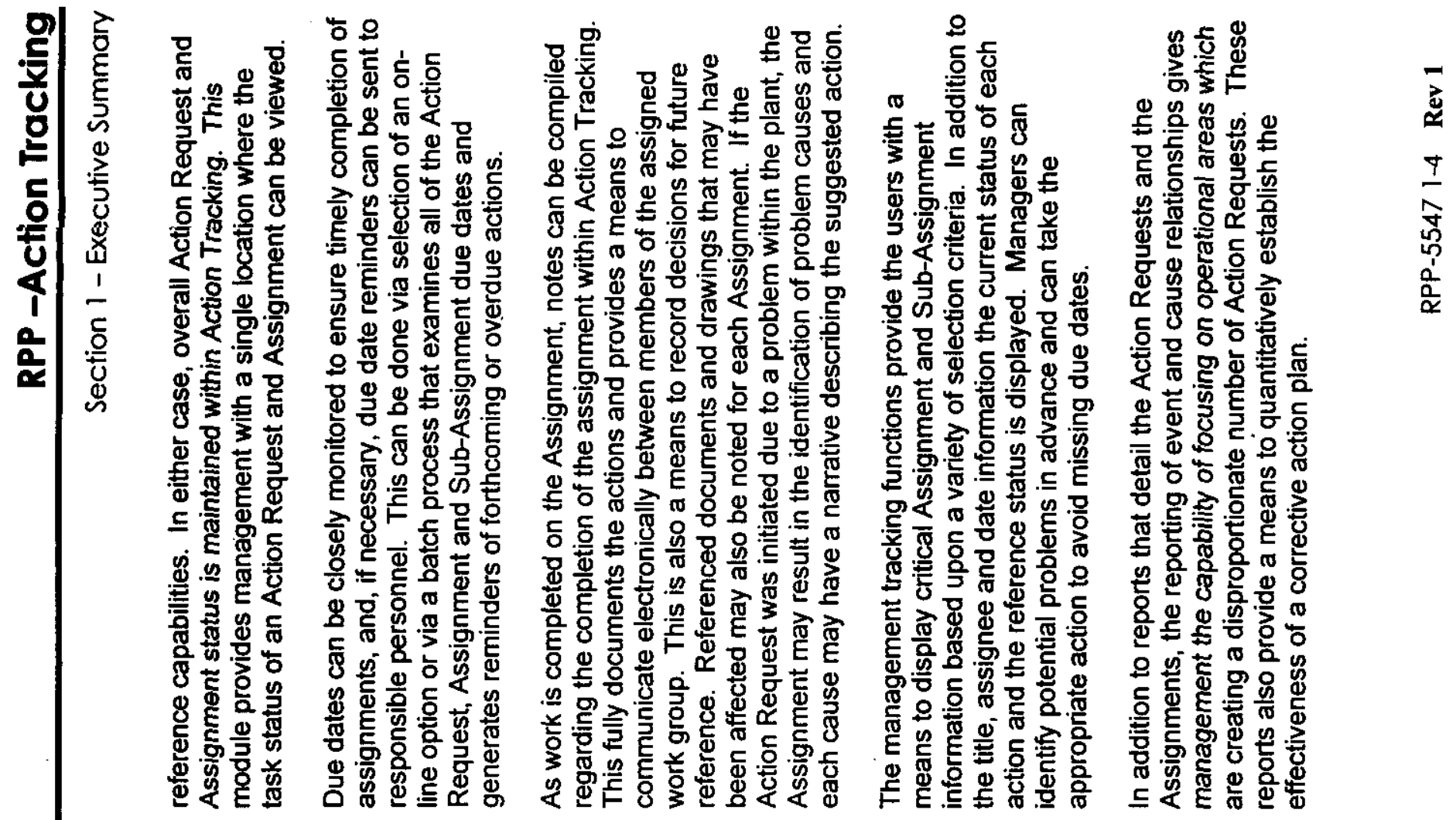

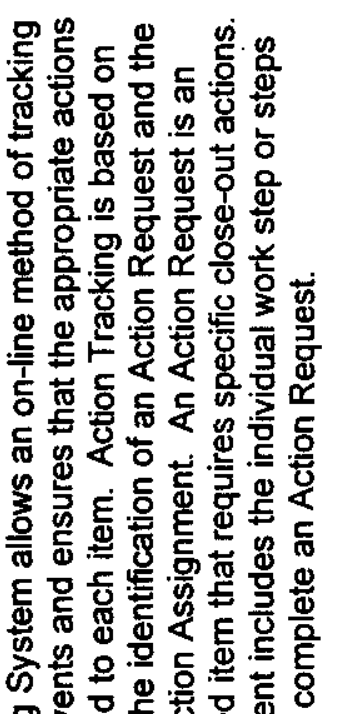

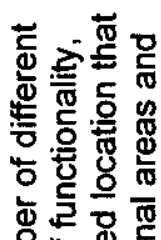

है융 음

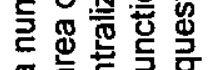

(ब)

突.

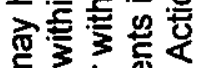

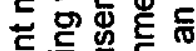

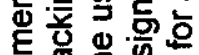

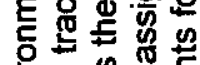

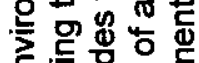

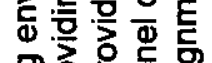

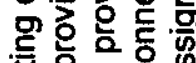

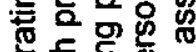

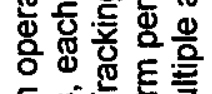

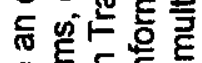

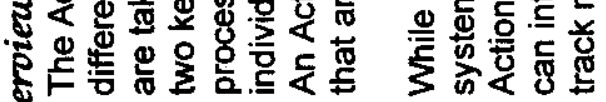

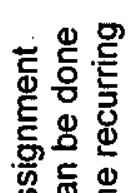

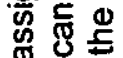

믈 윽

政

号 实

兽昰各

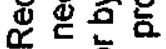

등 ㅎํㄷㄷㅇ

응 页응

$<$ 응

ब号

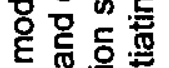

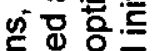

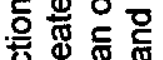

\%

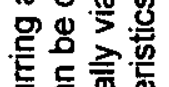

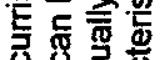

Q

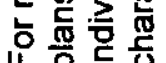

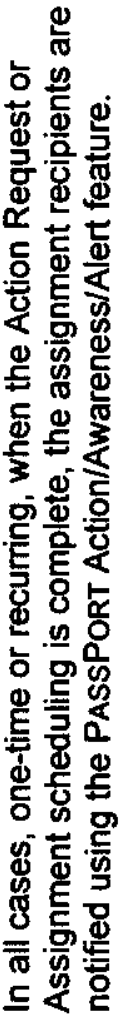

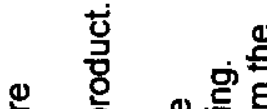

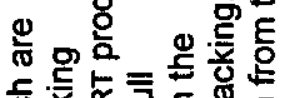

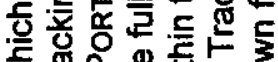

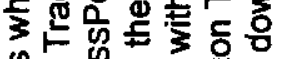

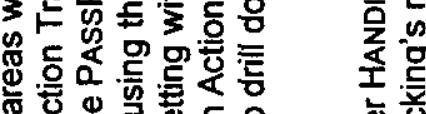

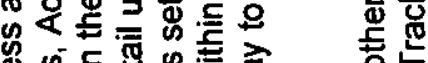

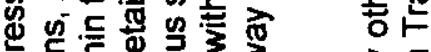

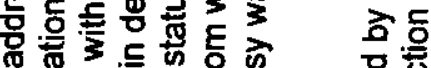

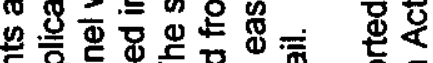

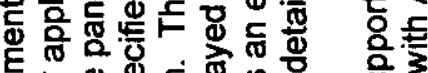

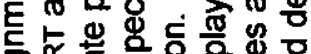

은 은

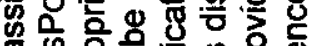

影

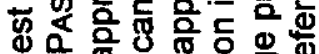

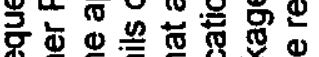

过言要은

둥ㅎㅇ응응

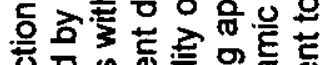

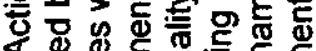

究

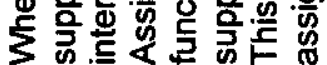

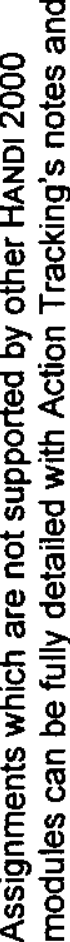



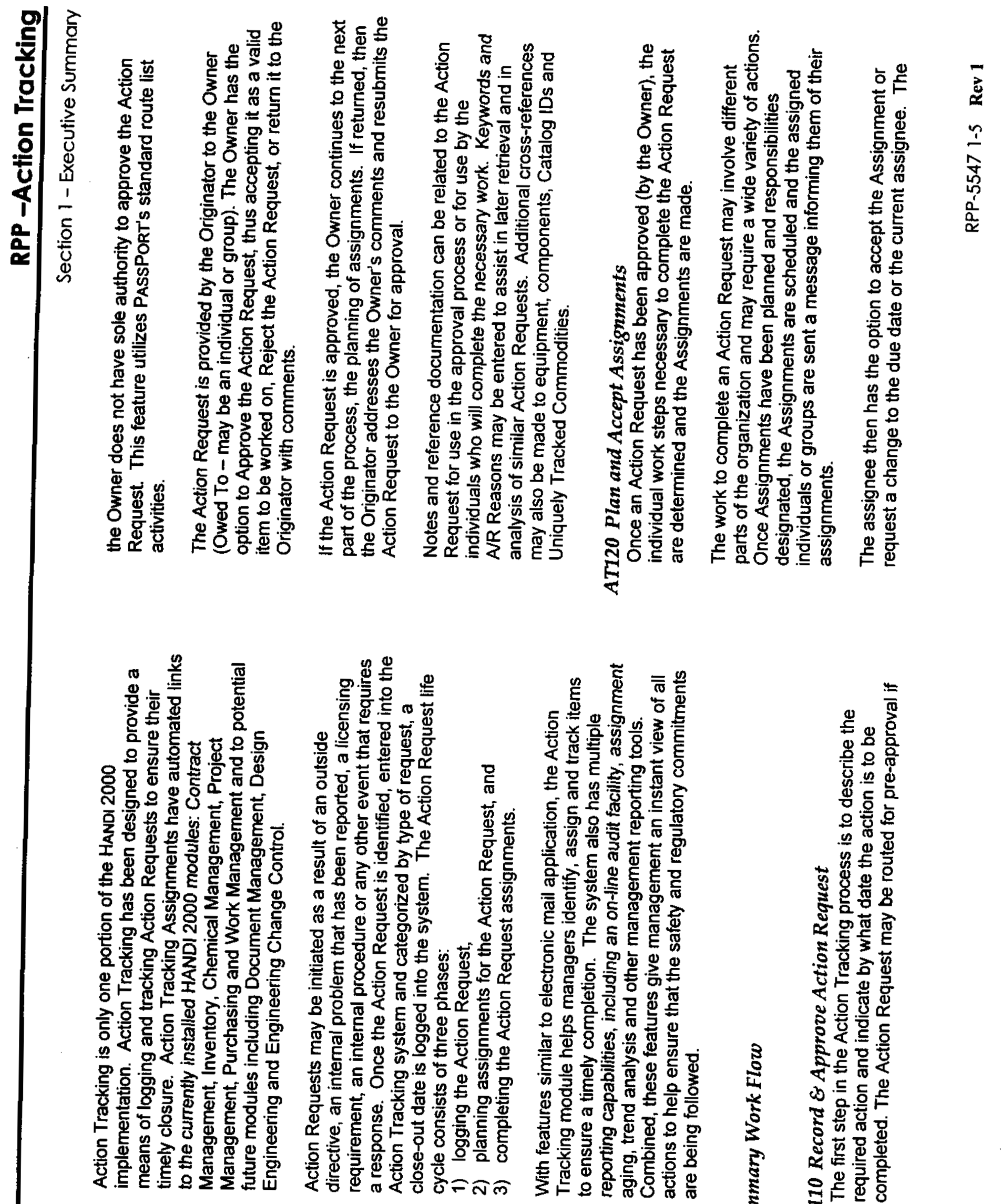

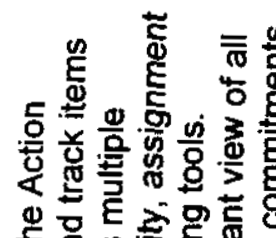

รักำำ

จำ

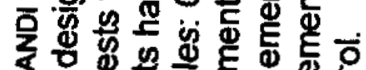

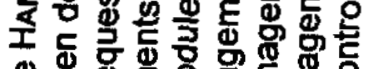

of

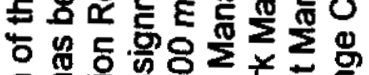

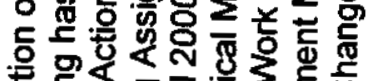

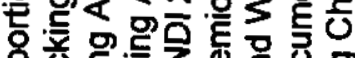

웡

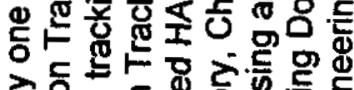

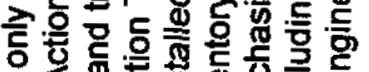

ำ

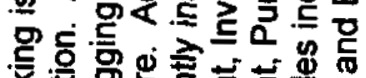

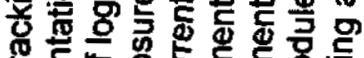

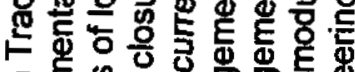

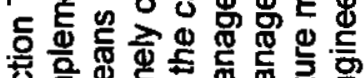

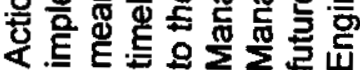

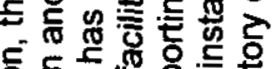

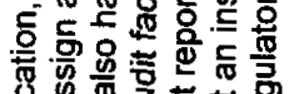

음

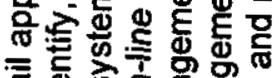

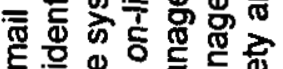

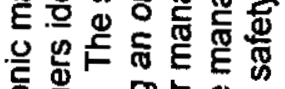

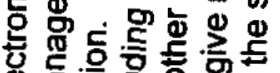

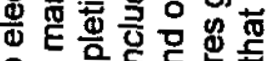

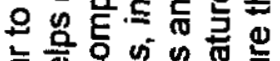

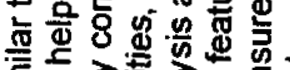

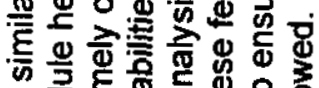

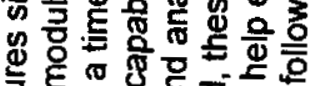

声它

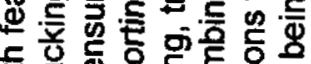

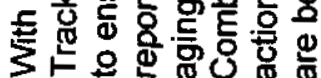

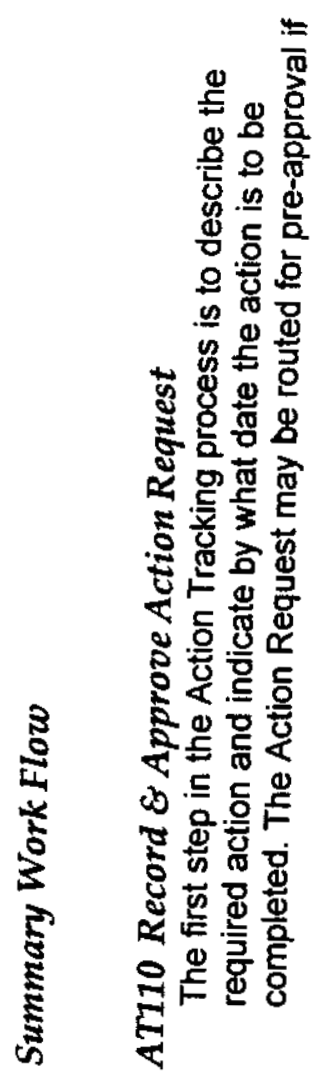




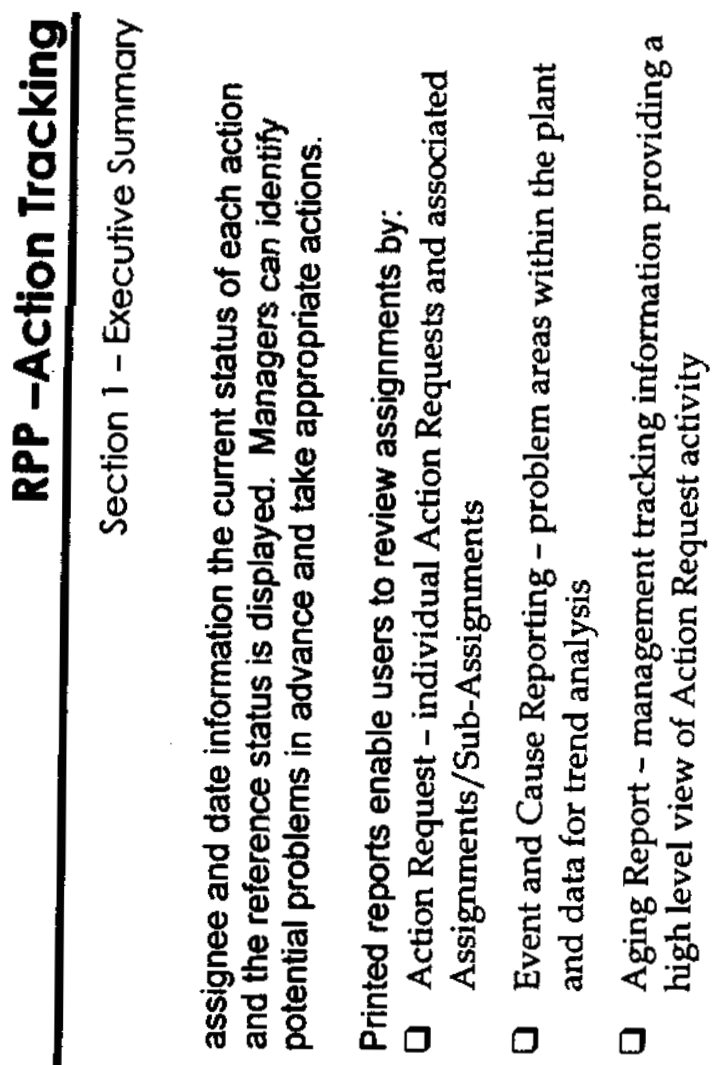
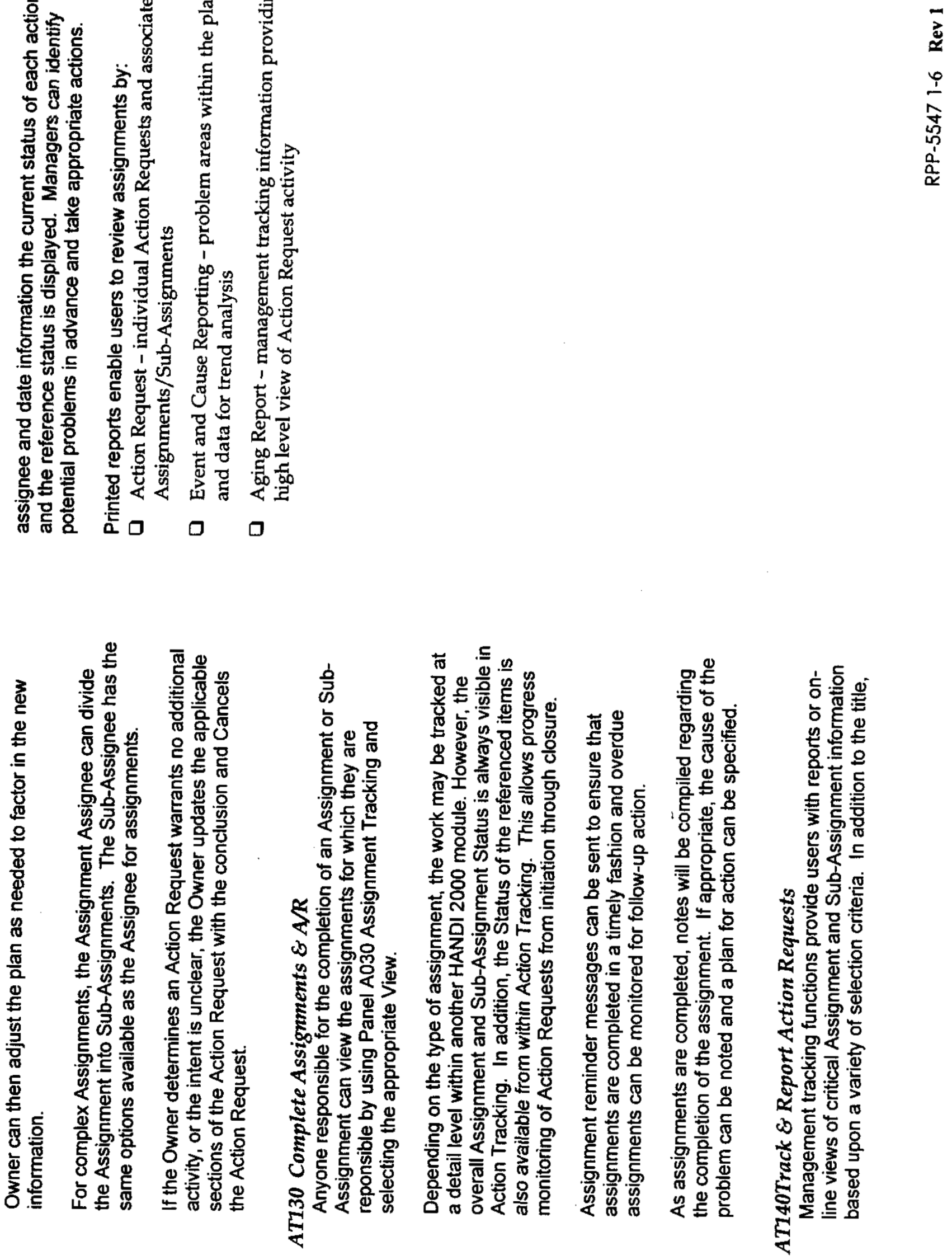

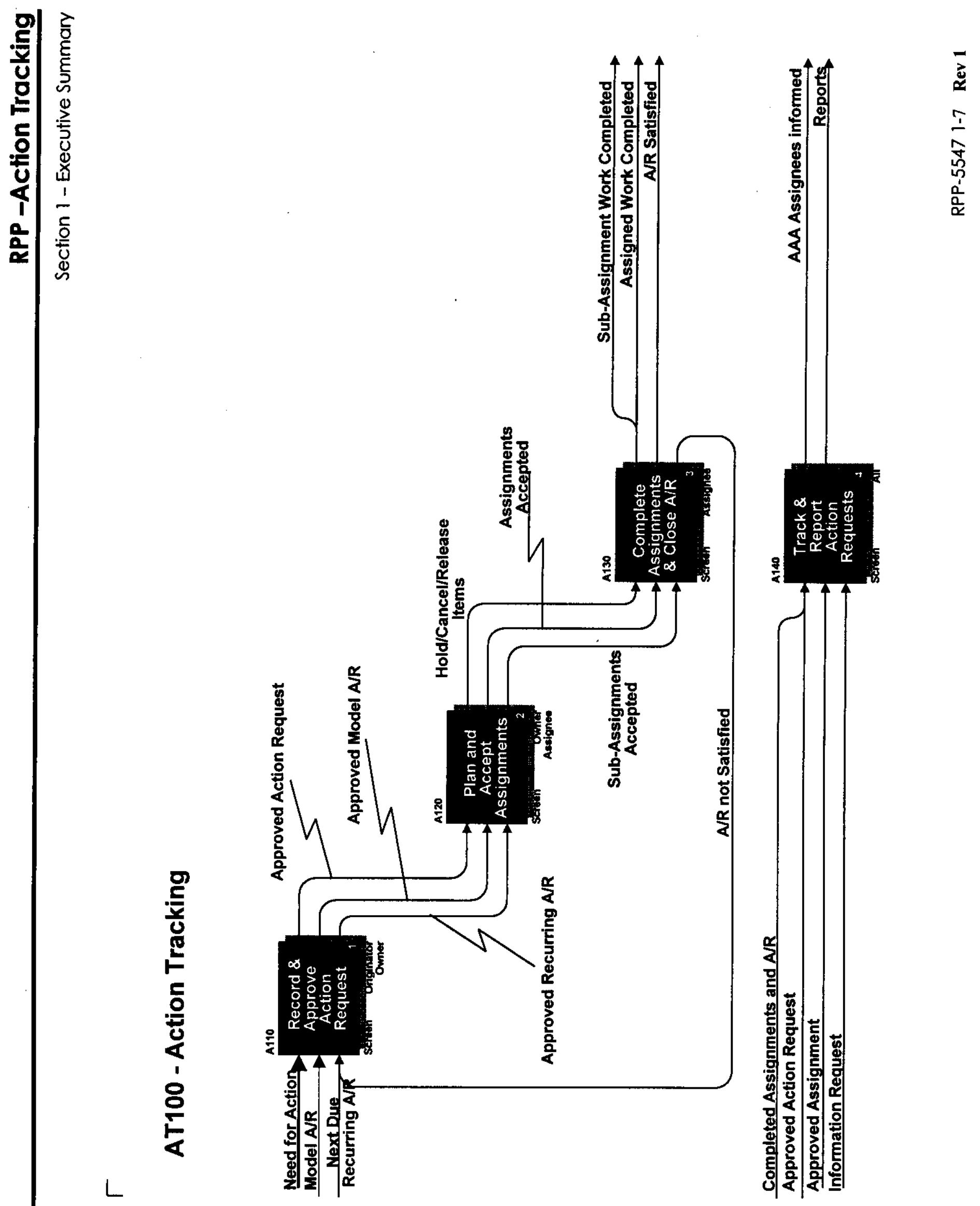

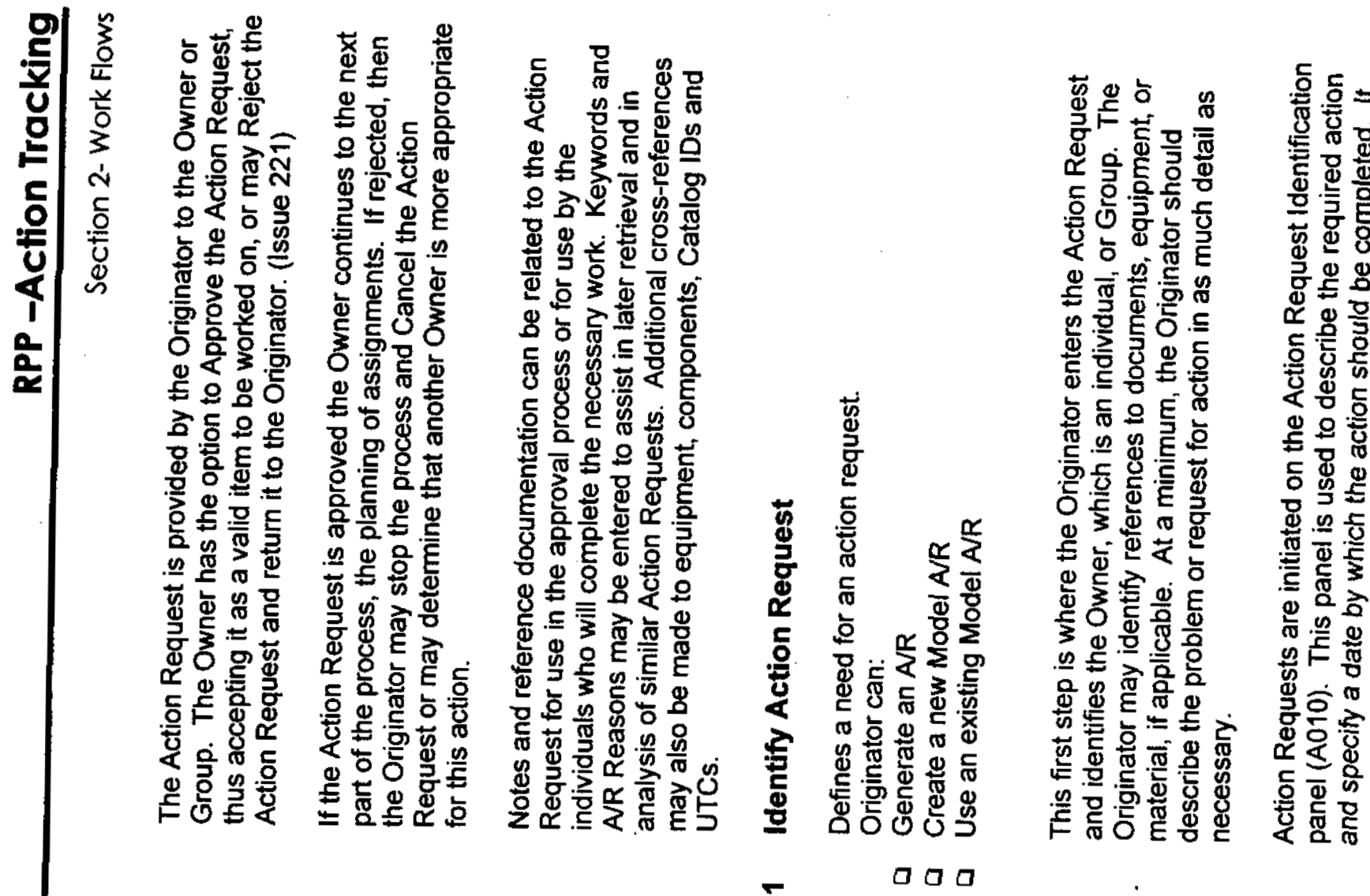

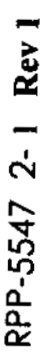
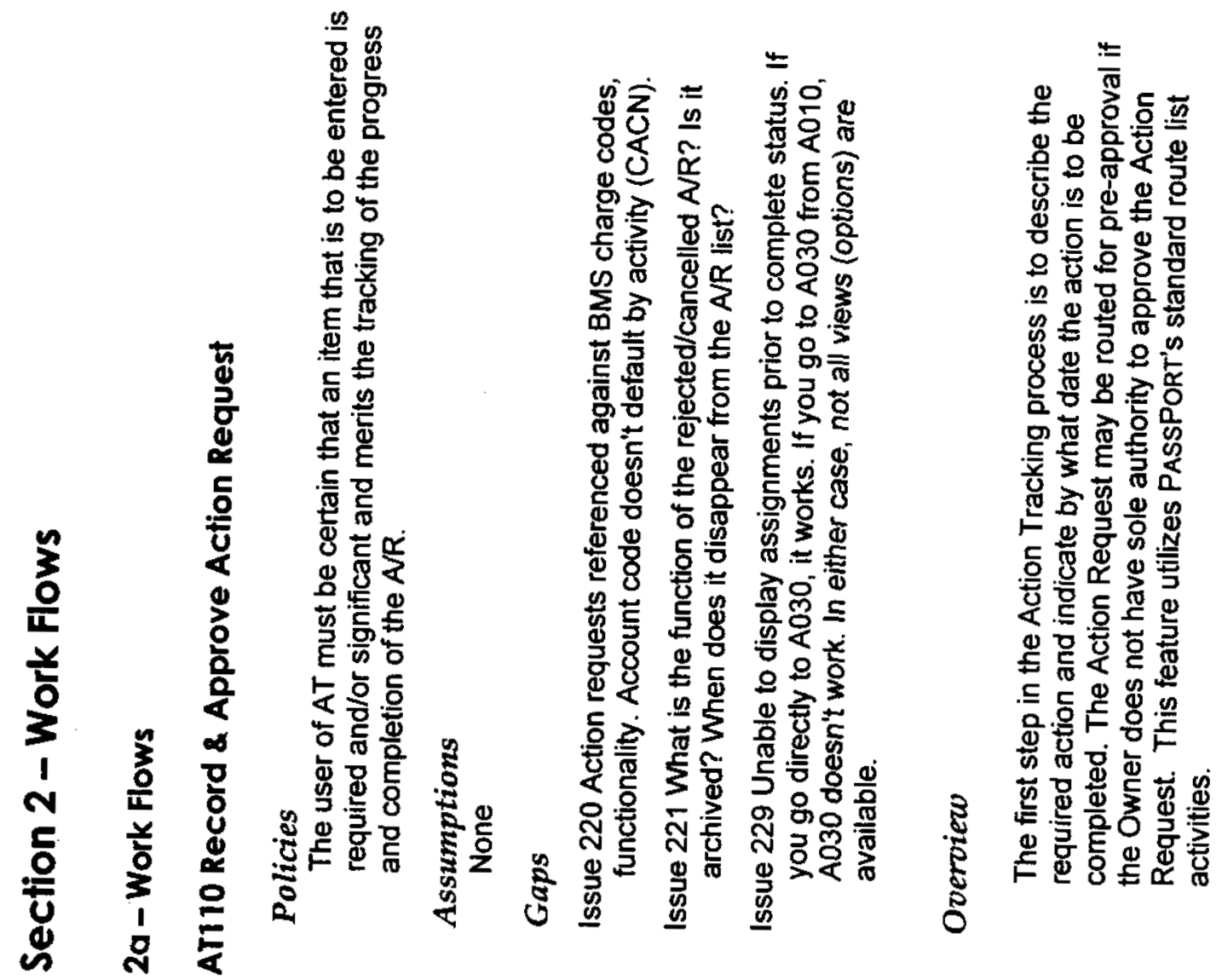


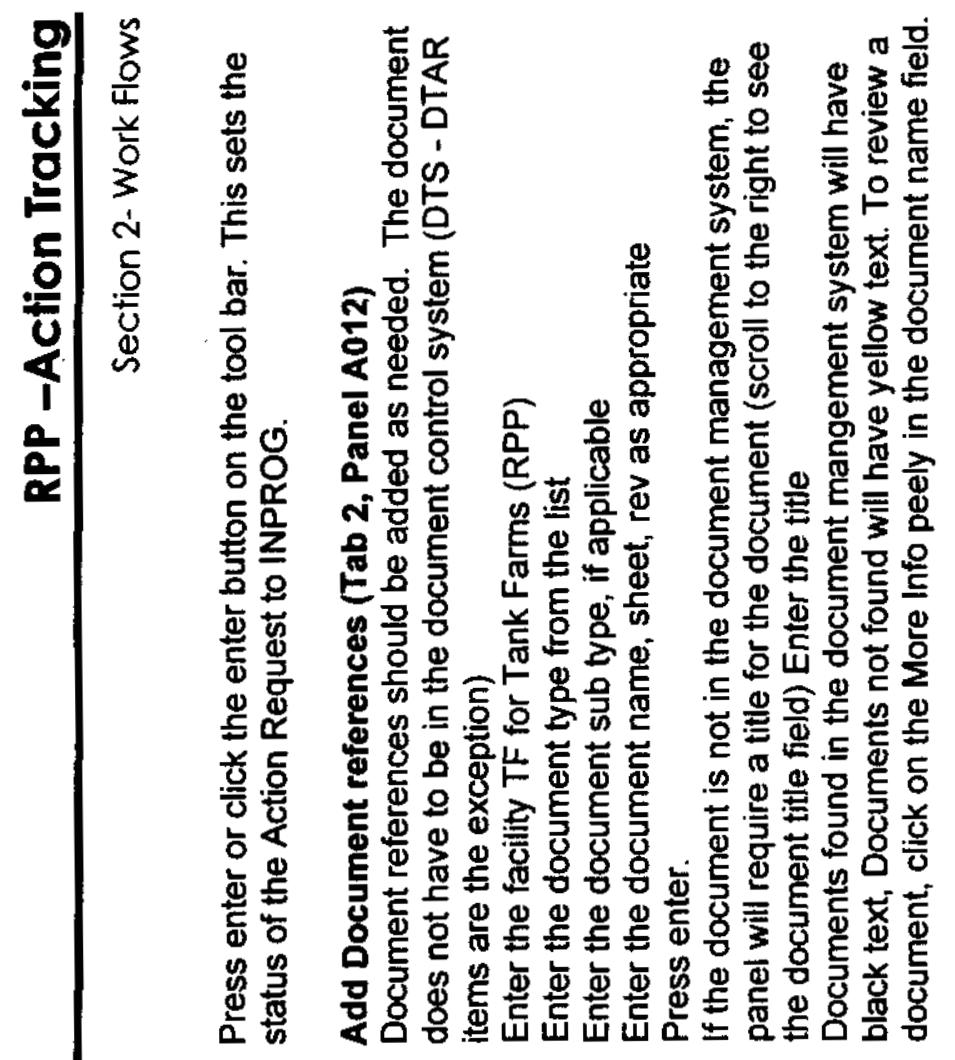
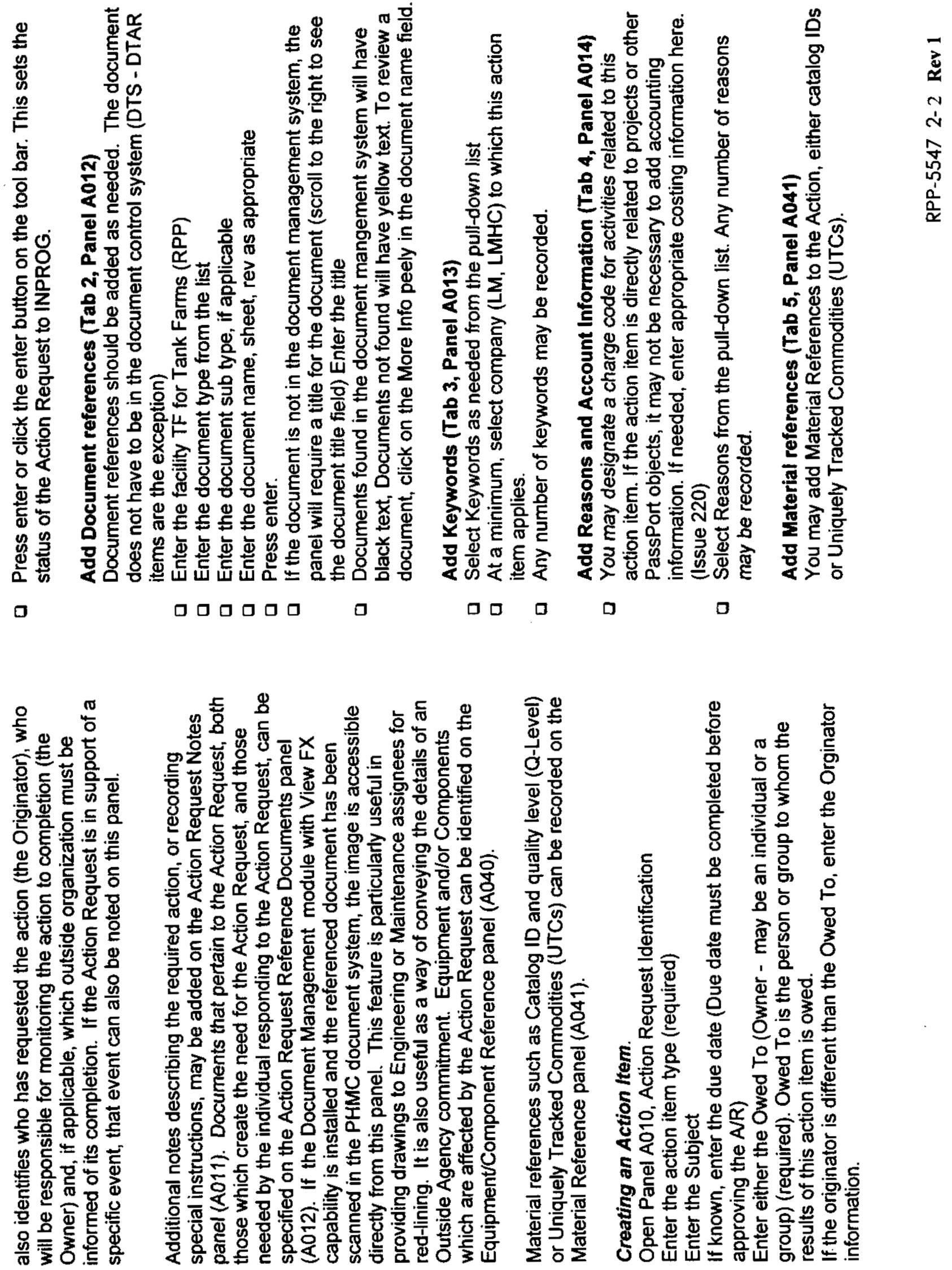

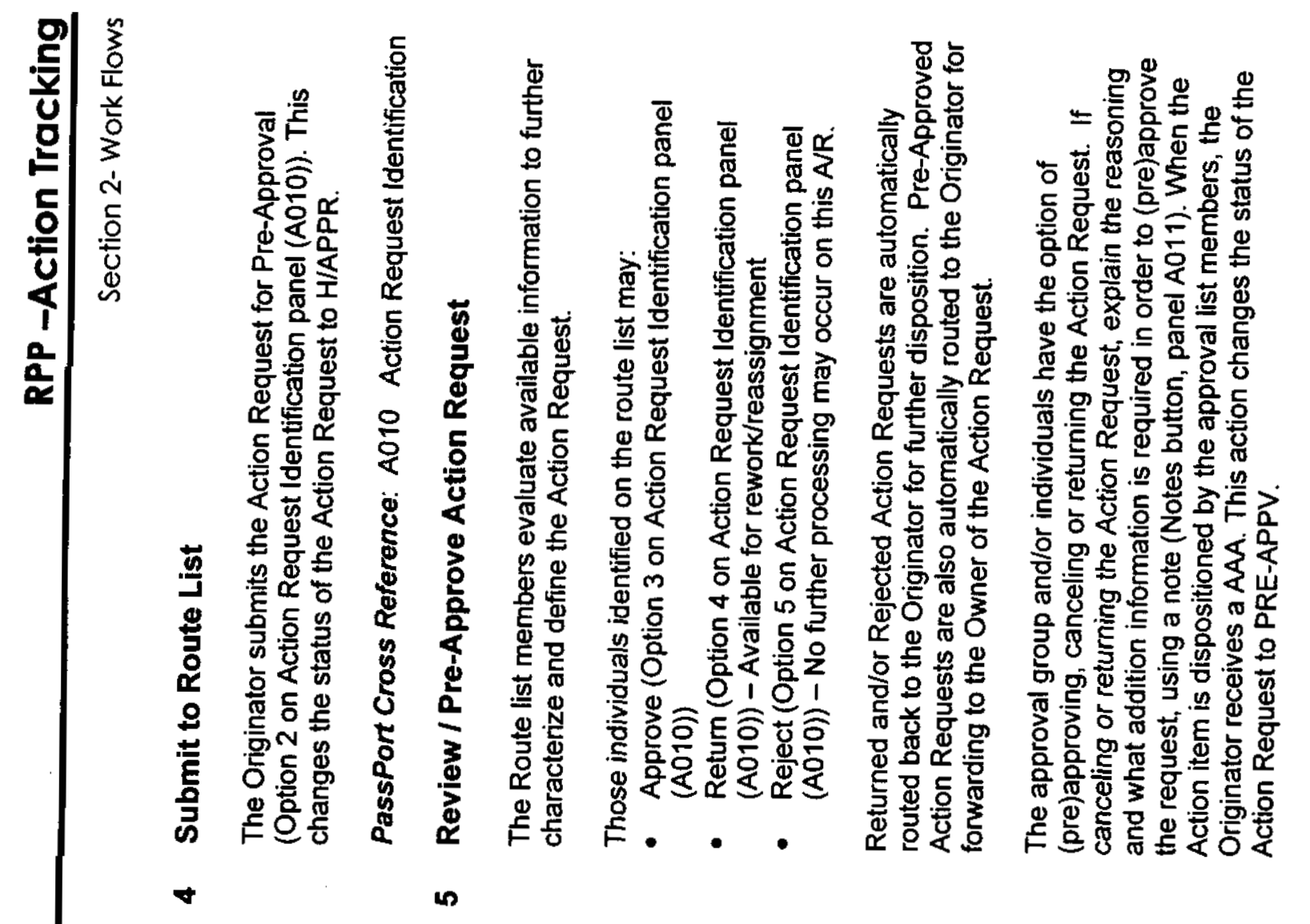

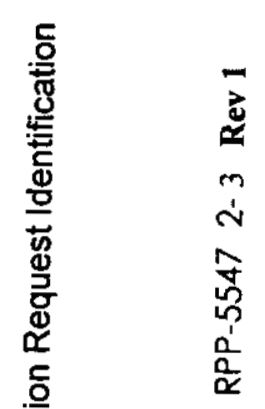

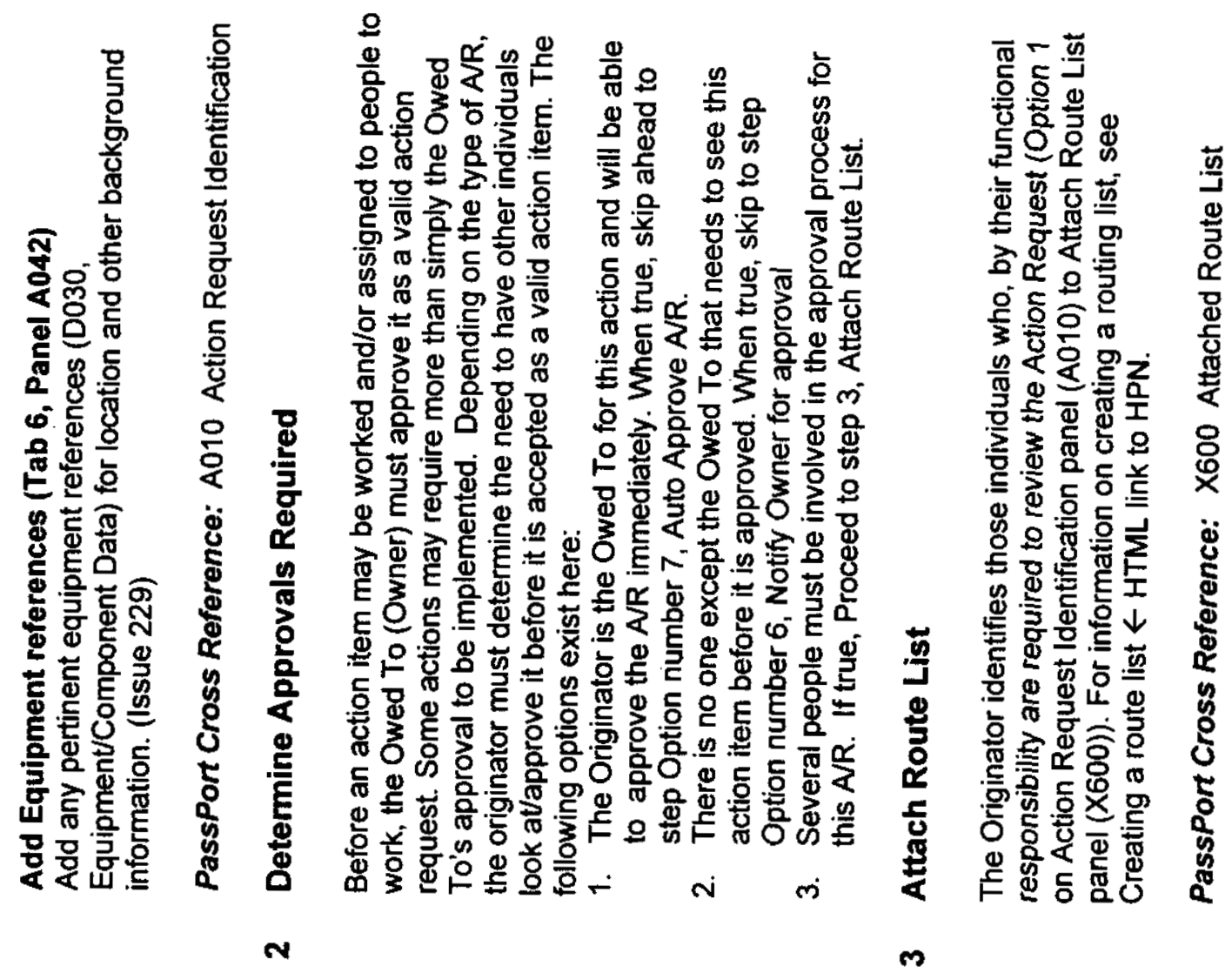



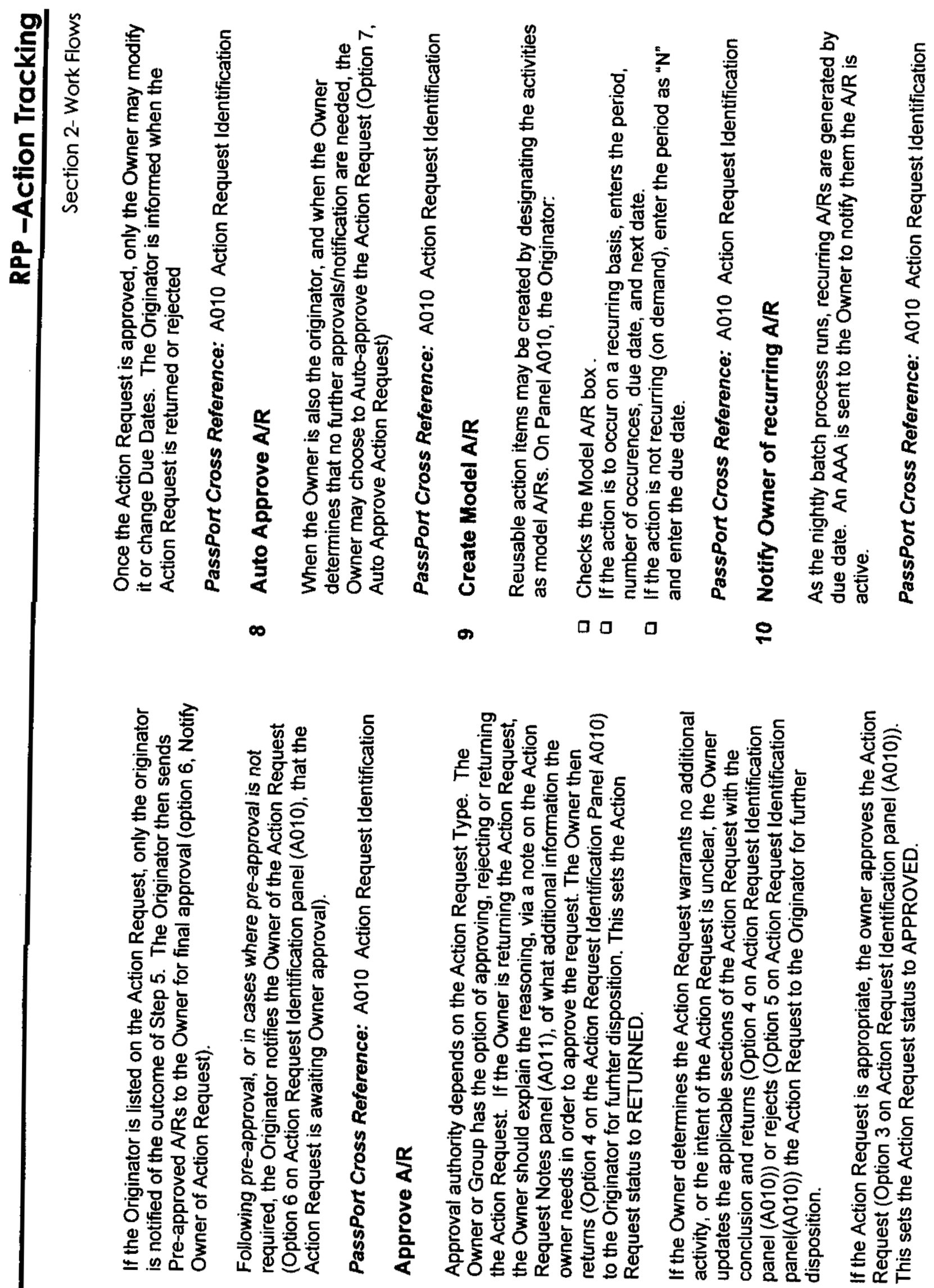


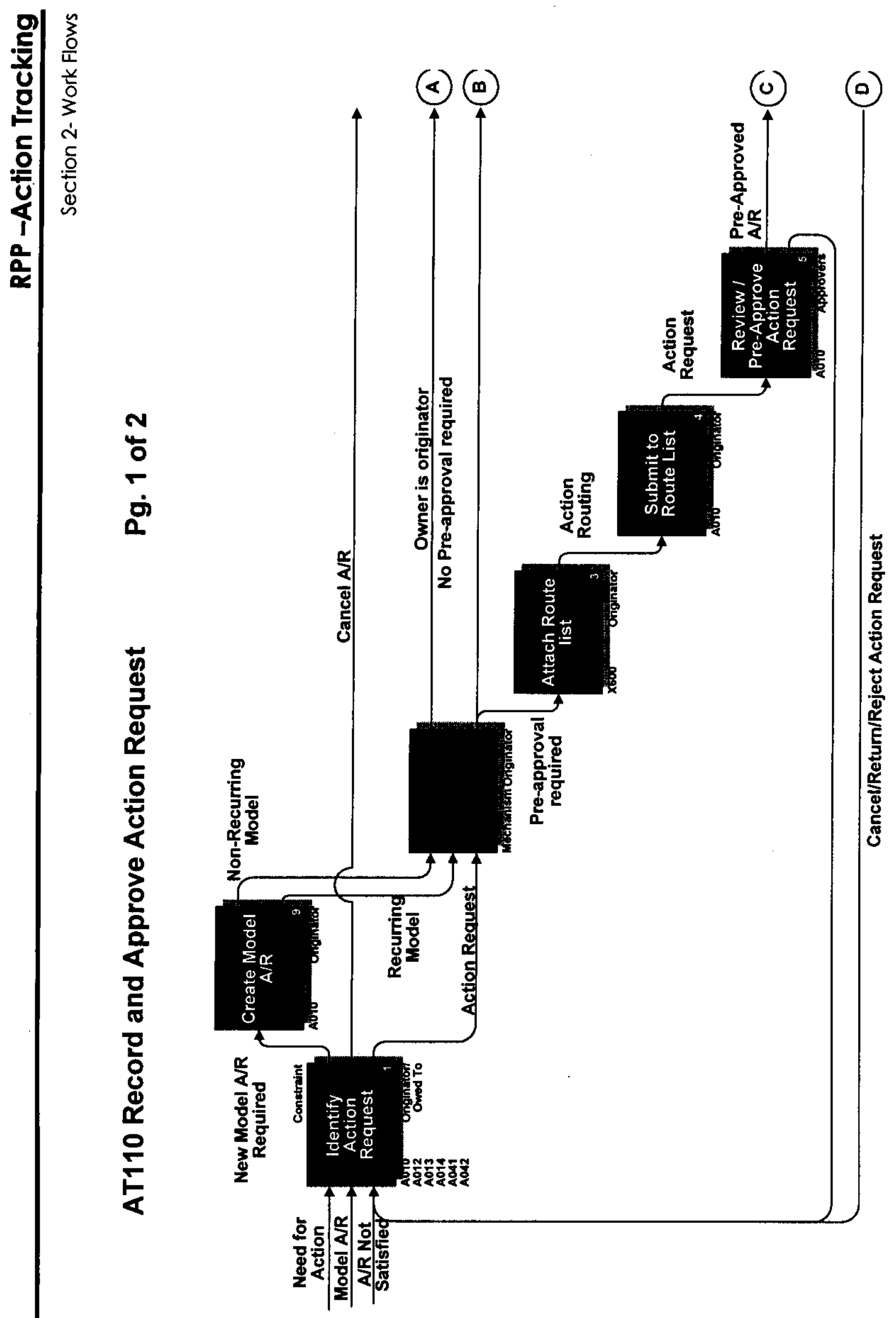




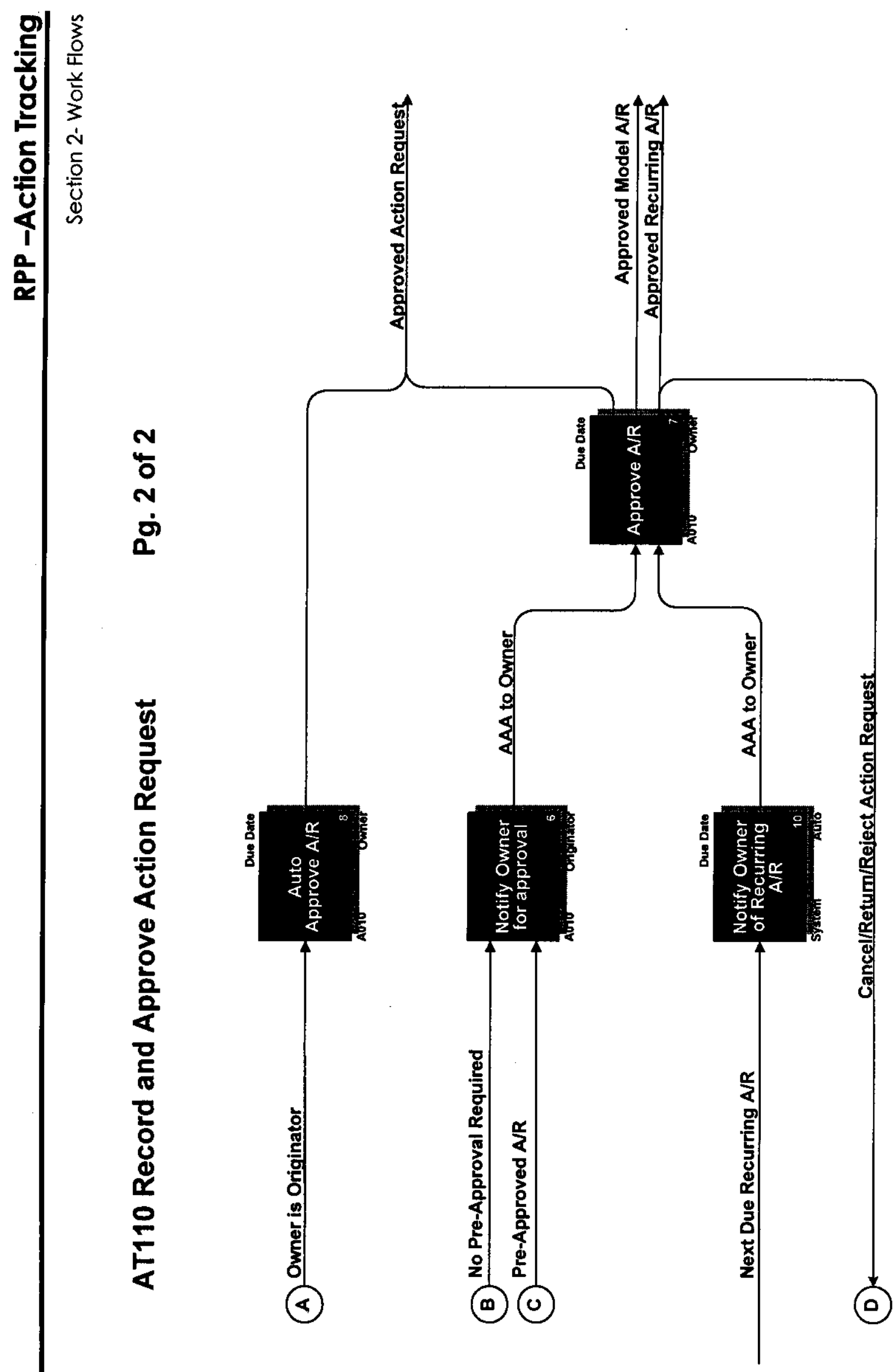




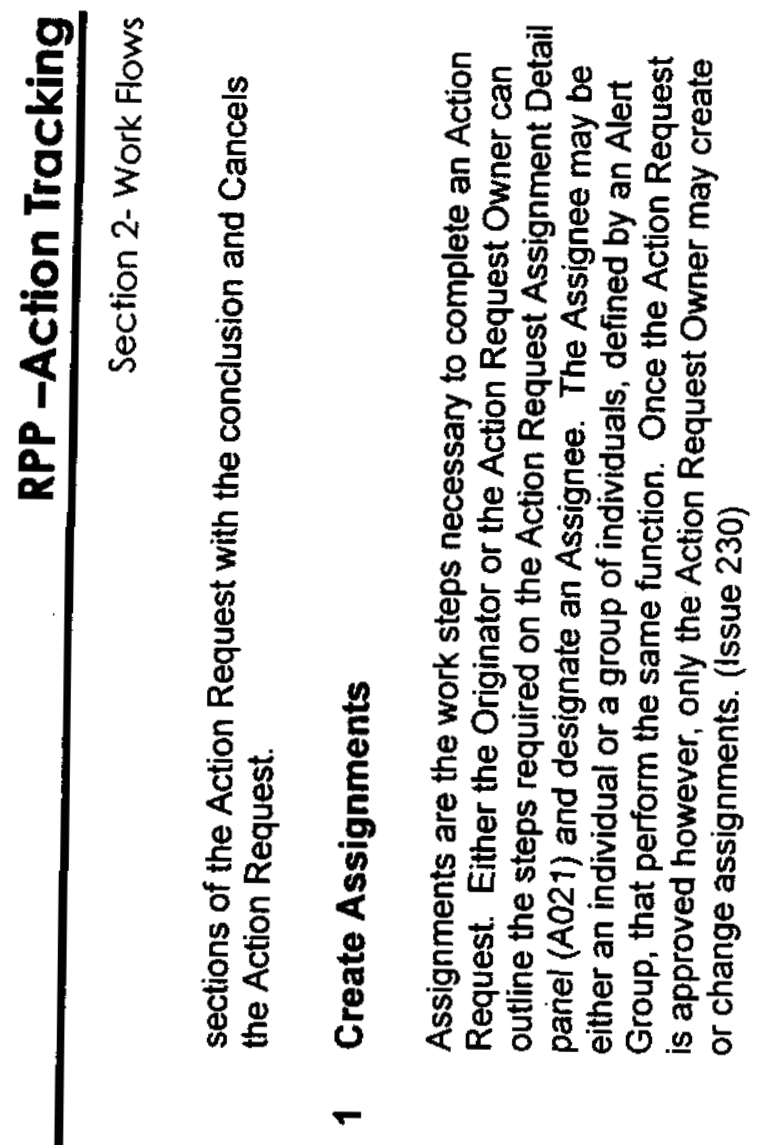

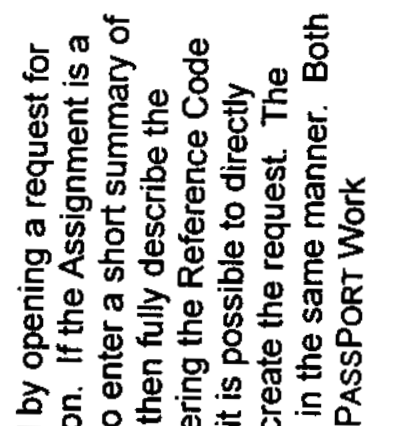

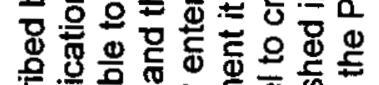

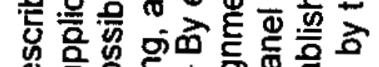

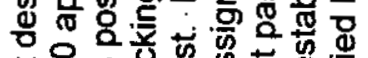

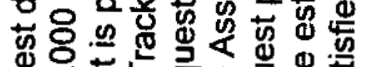

هㄴ.

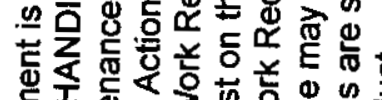

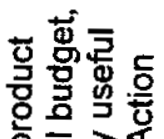

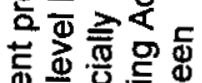

등

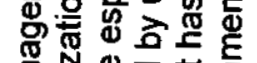

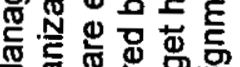

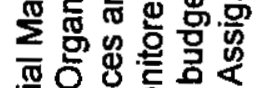

元

焉娄

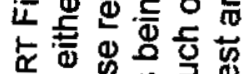

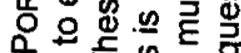

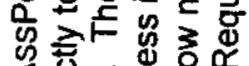

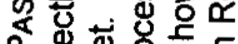

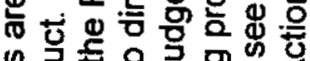

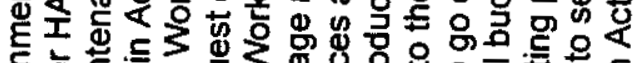

원.

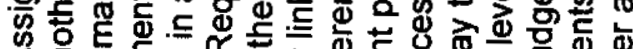

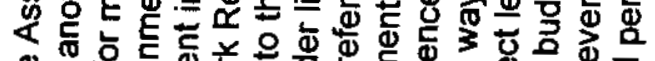

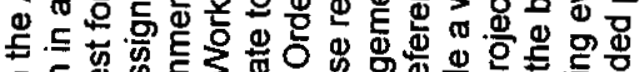

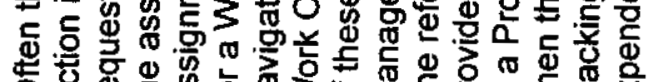

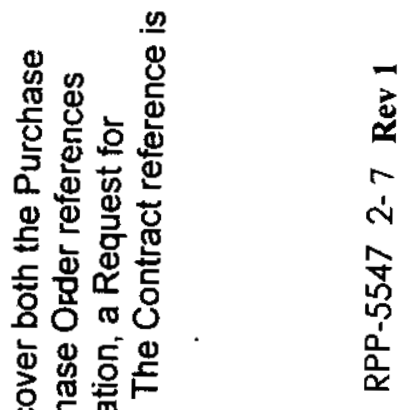

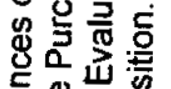

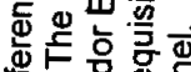

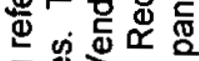

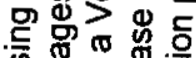

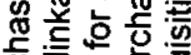
는 苏要

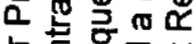
농혀웛

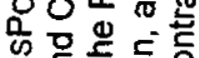

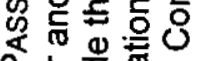

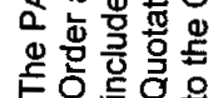

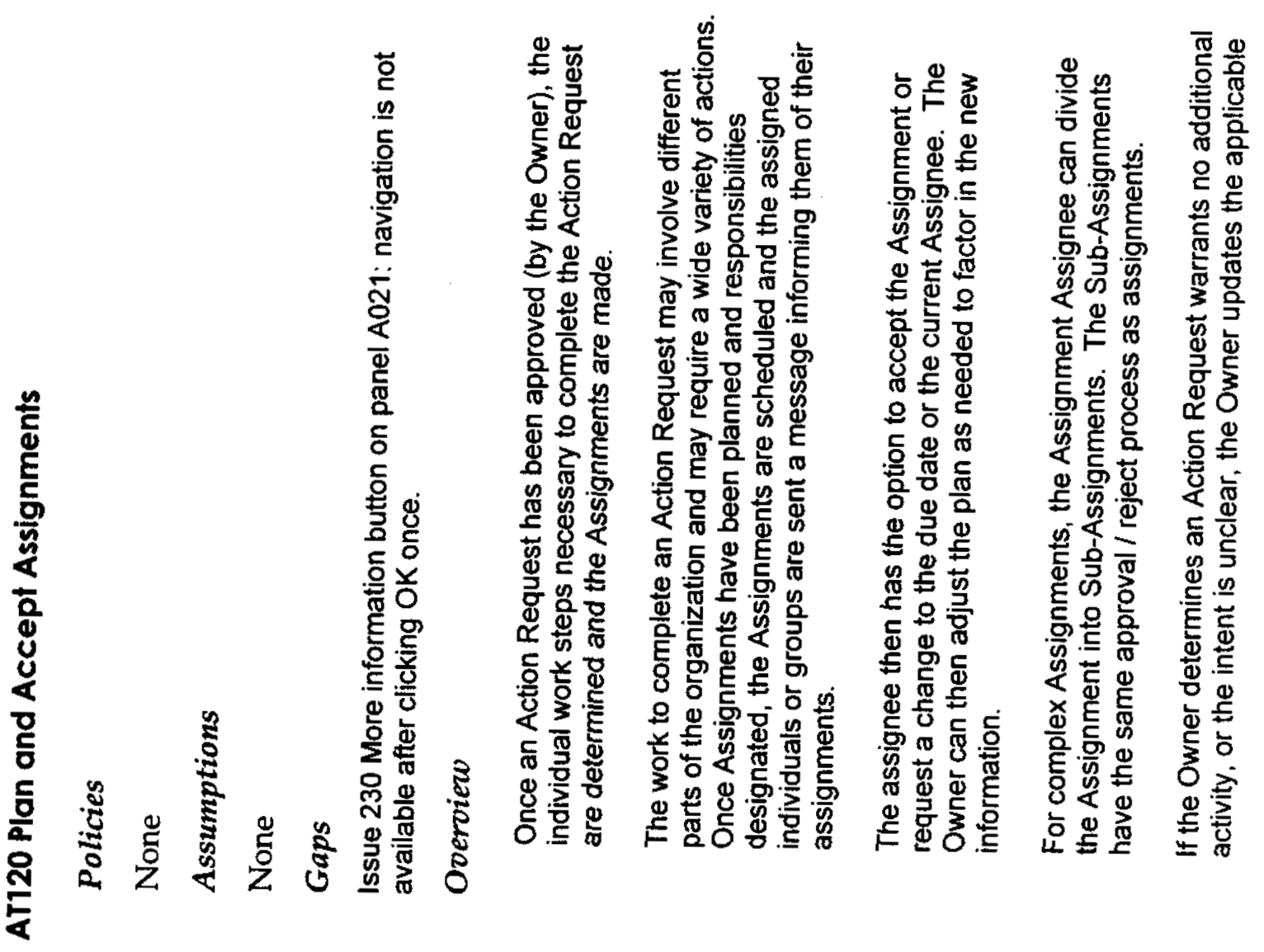



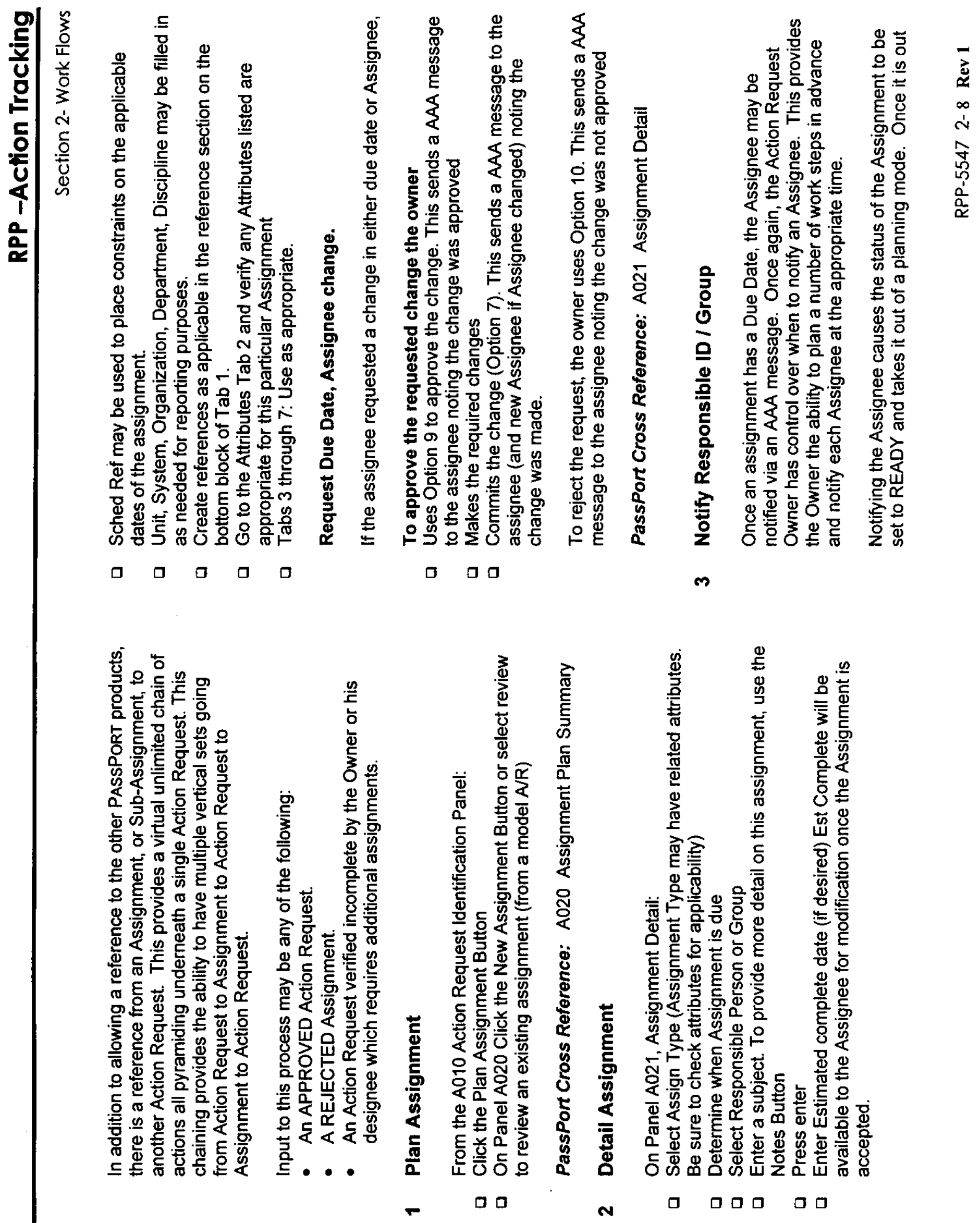


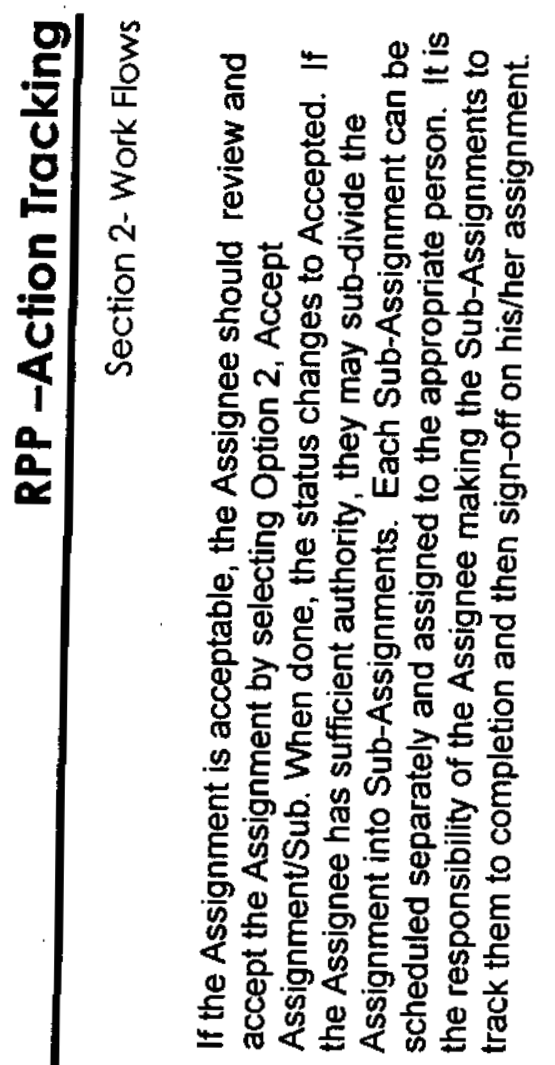
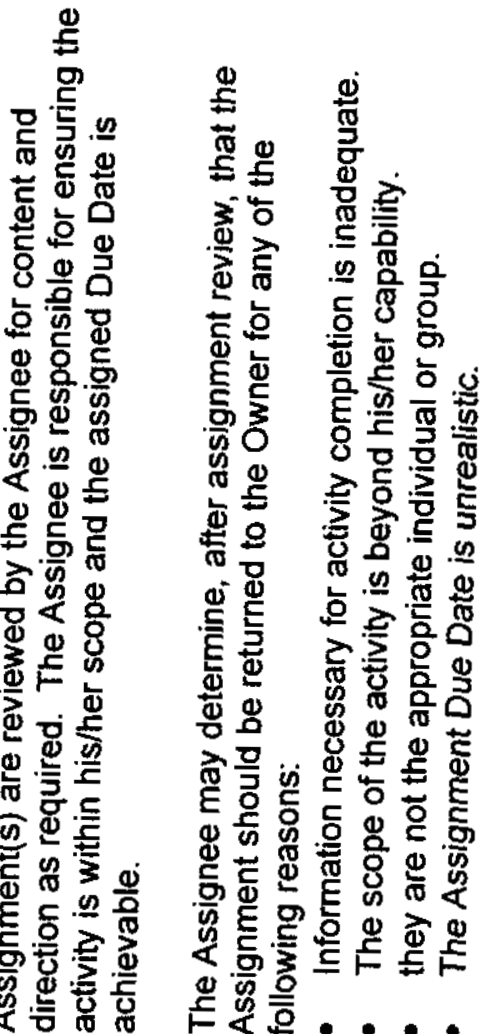

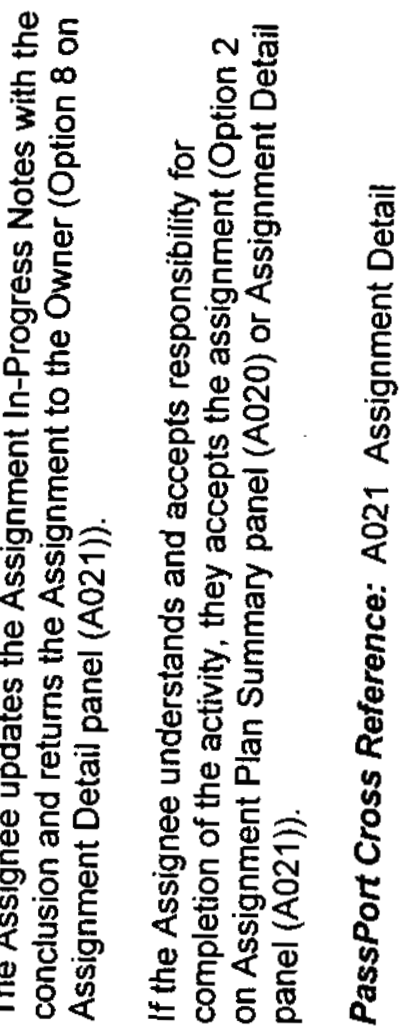

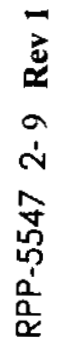
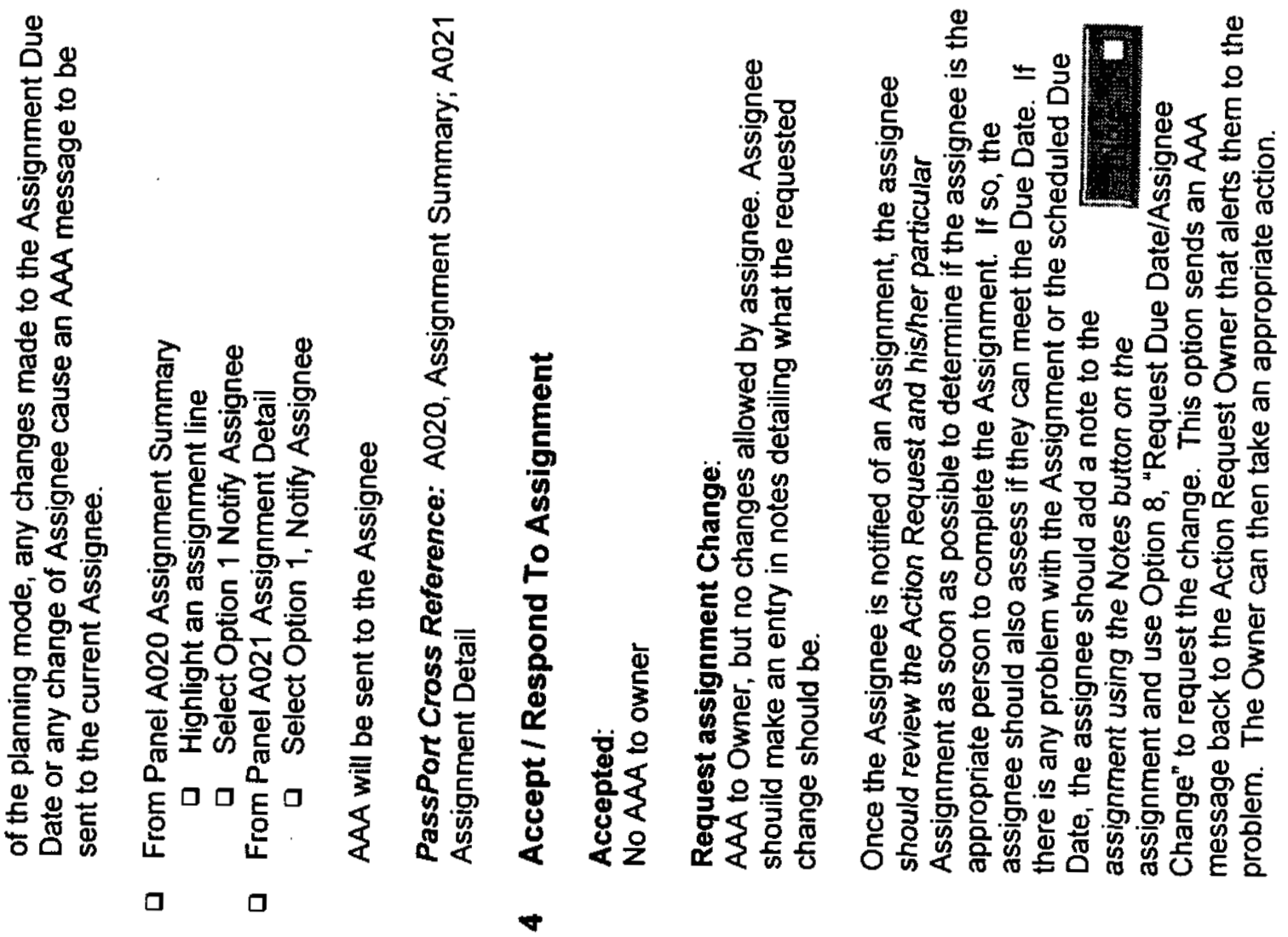


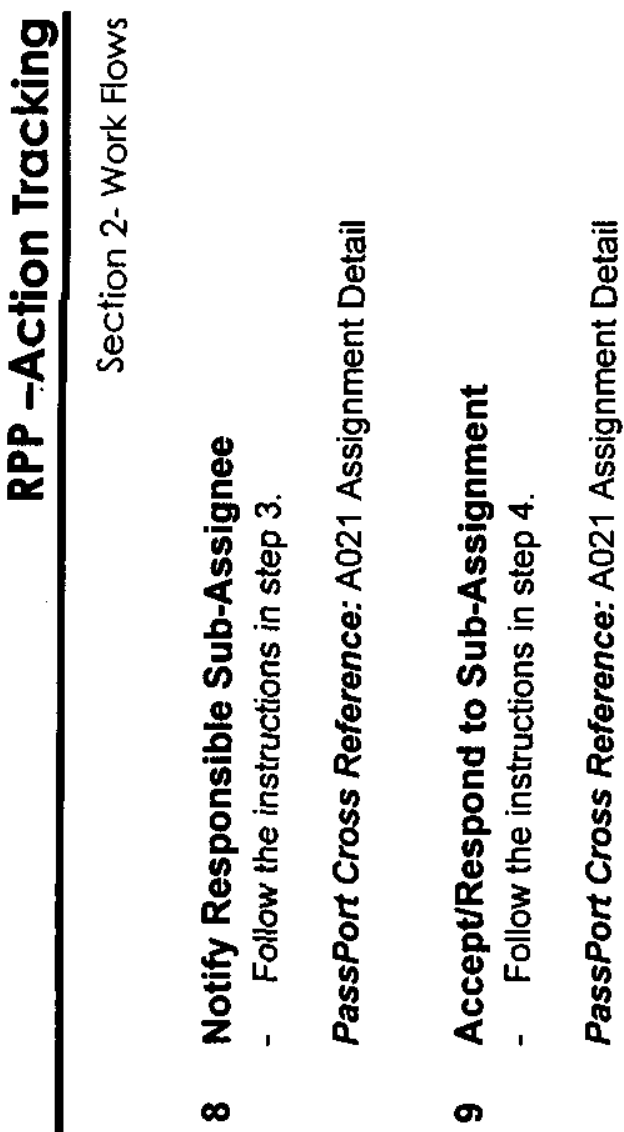

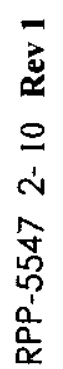
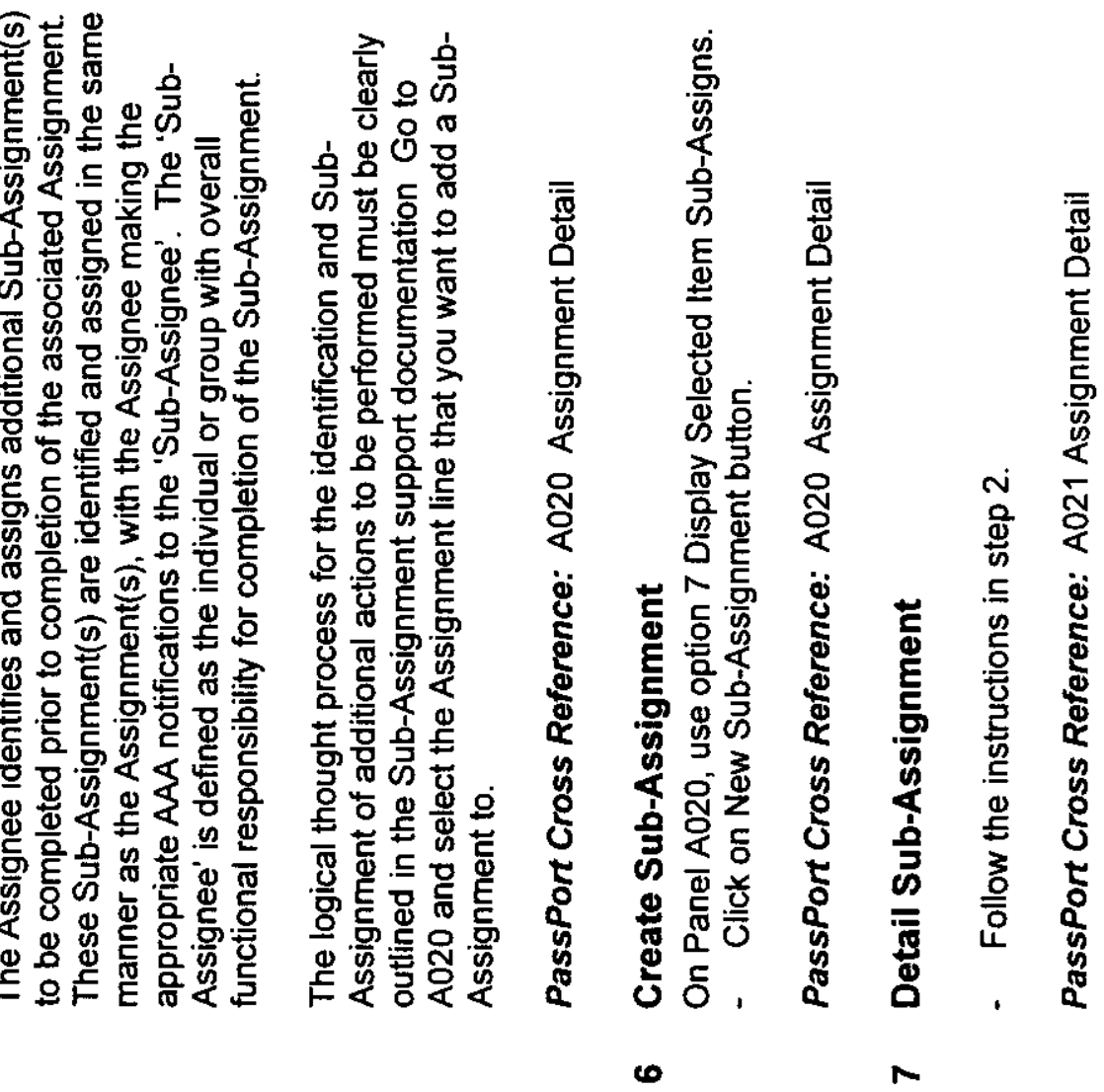

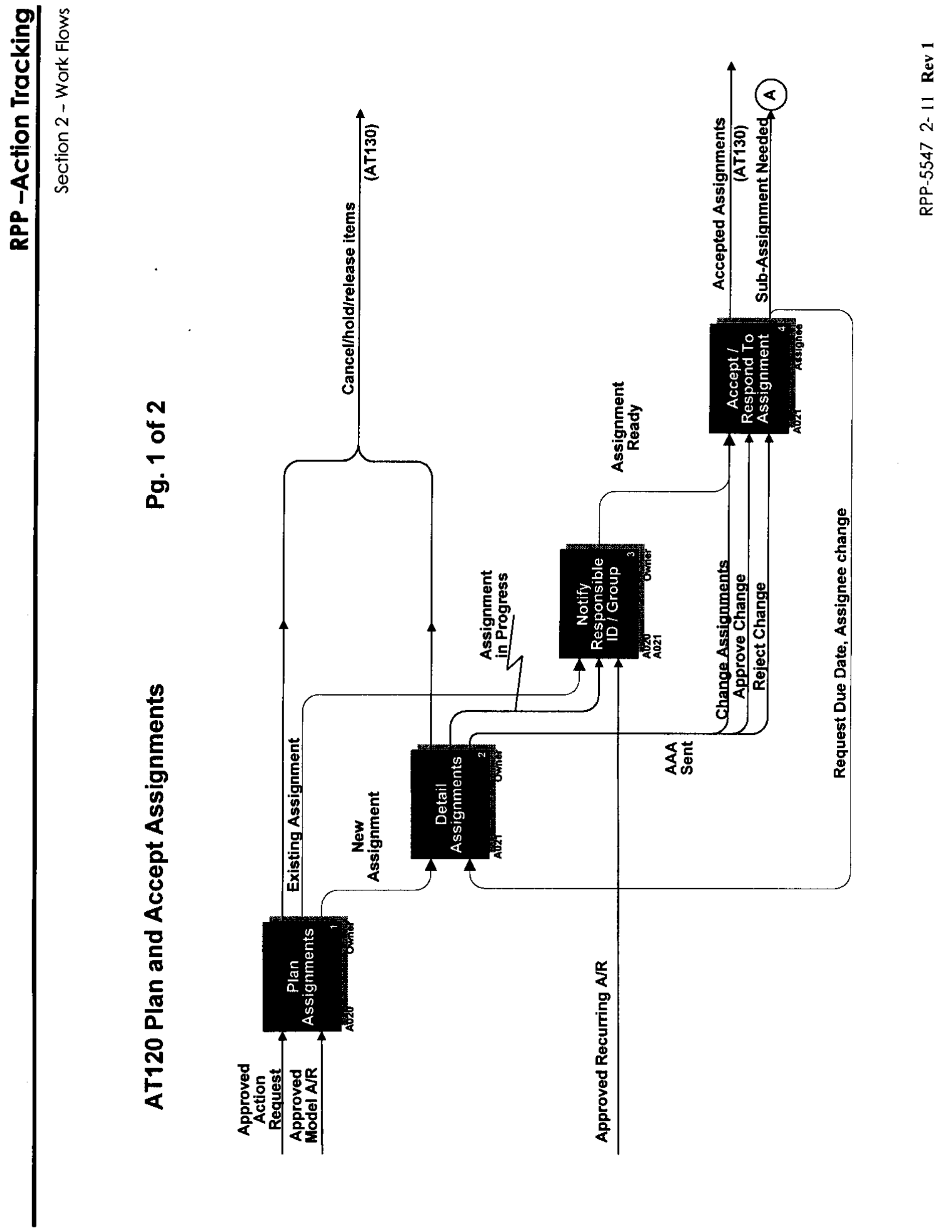


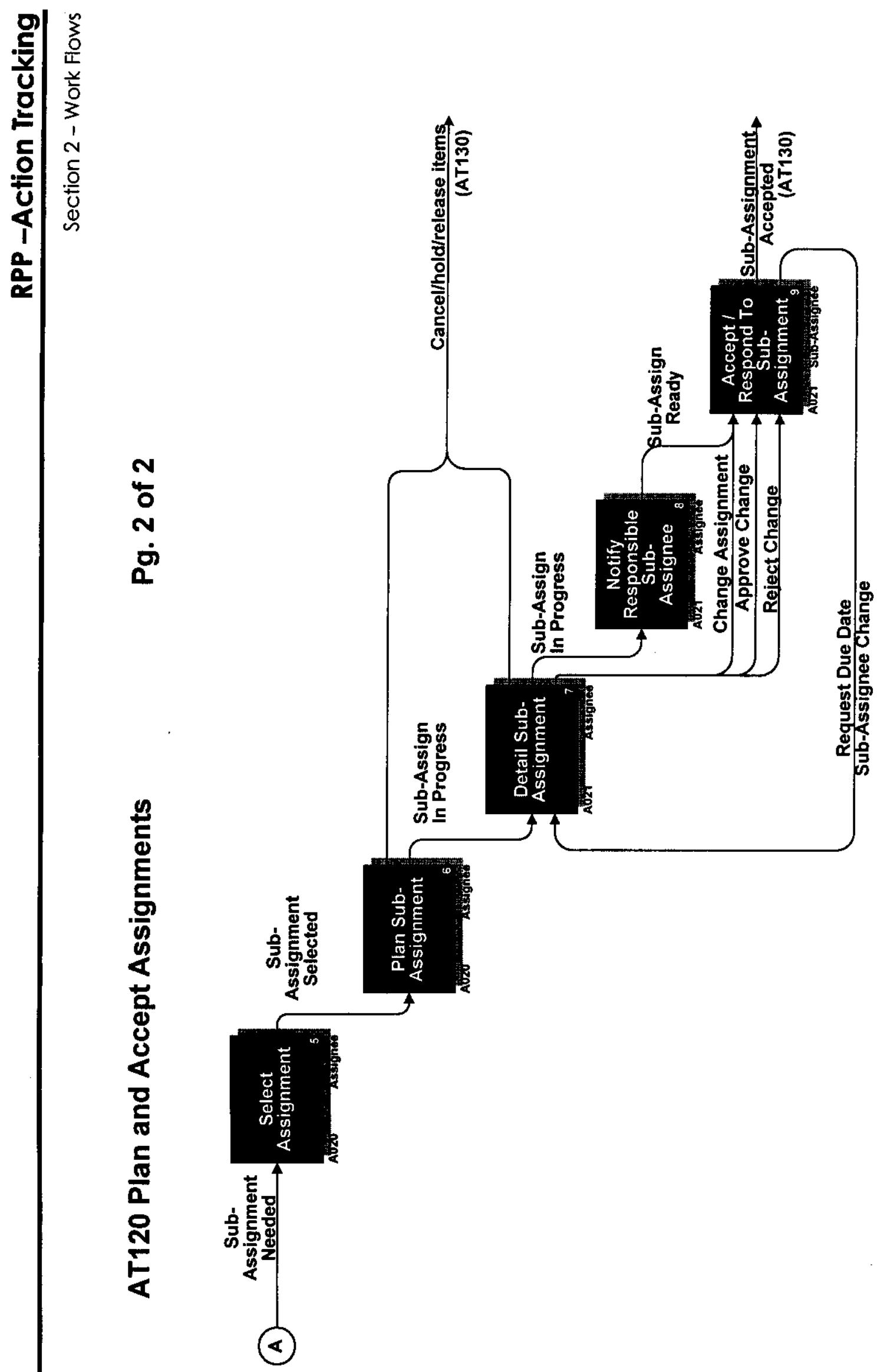

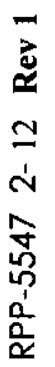



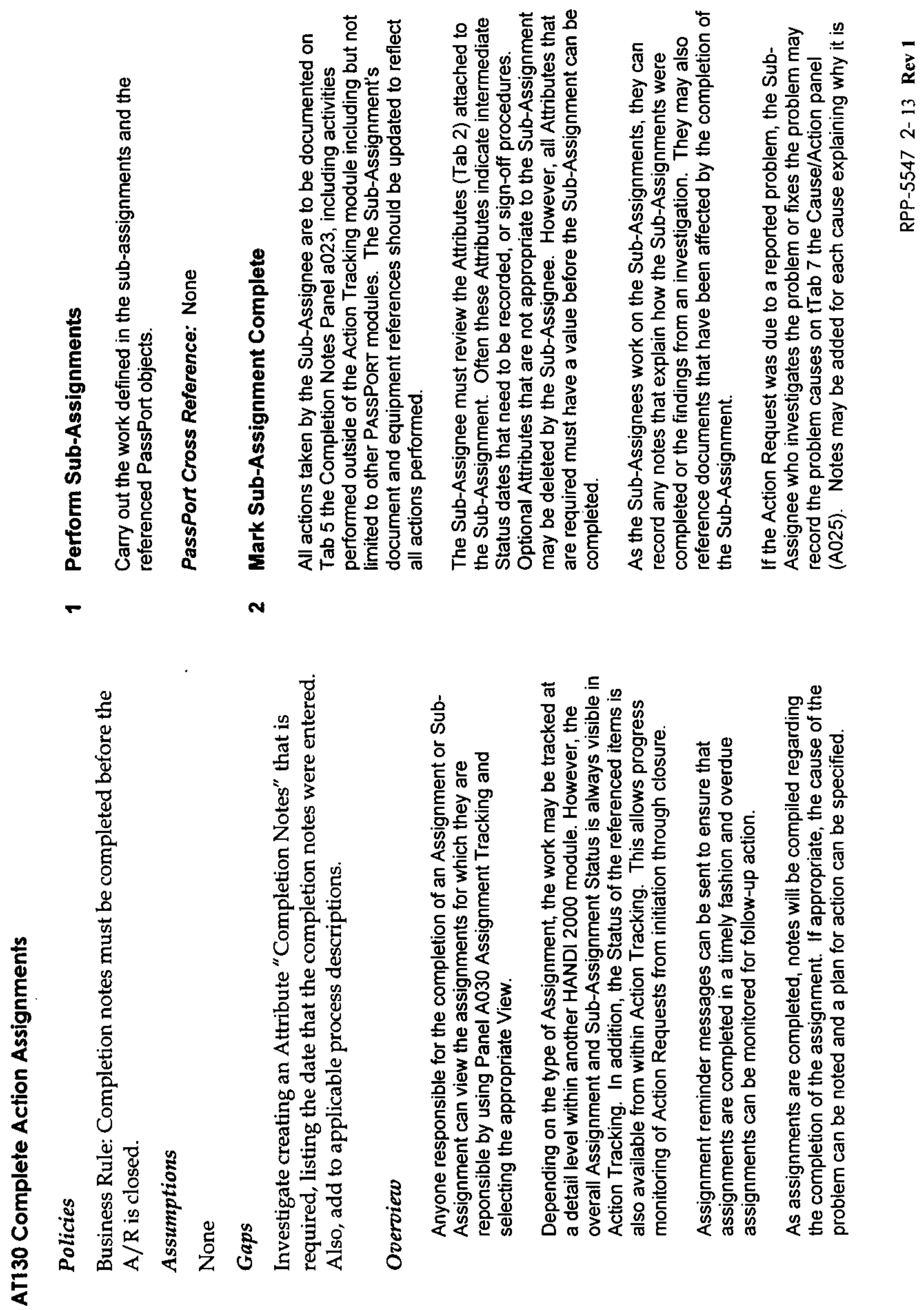

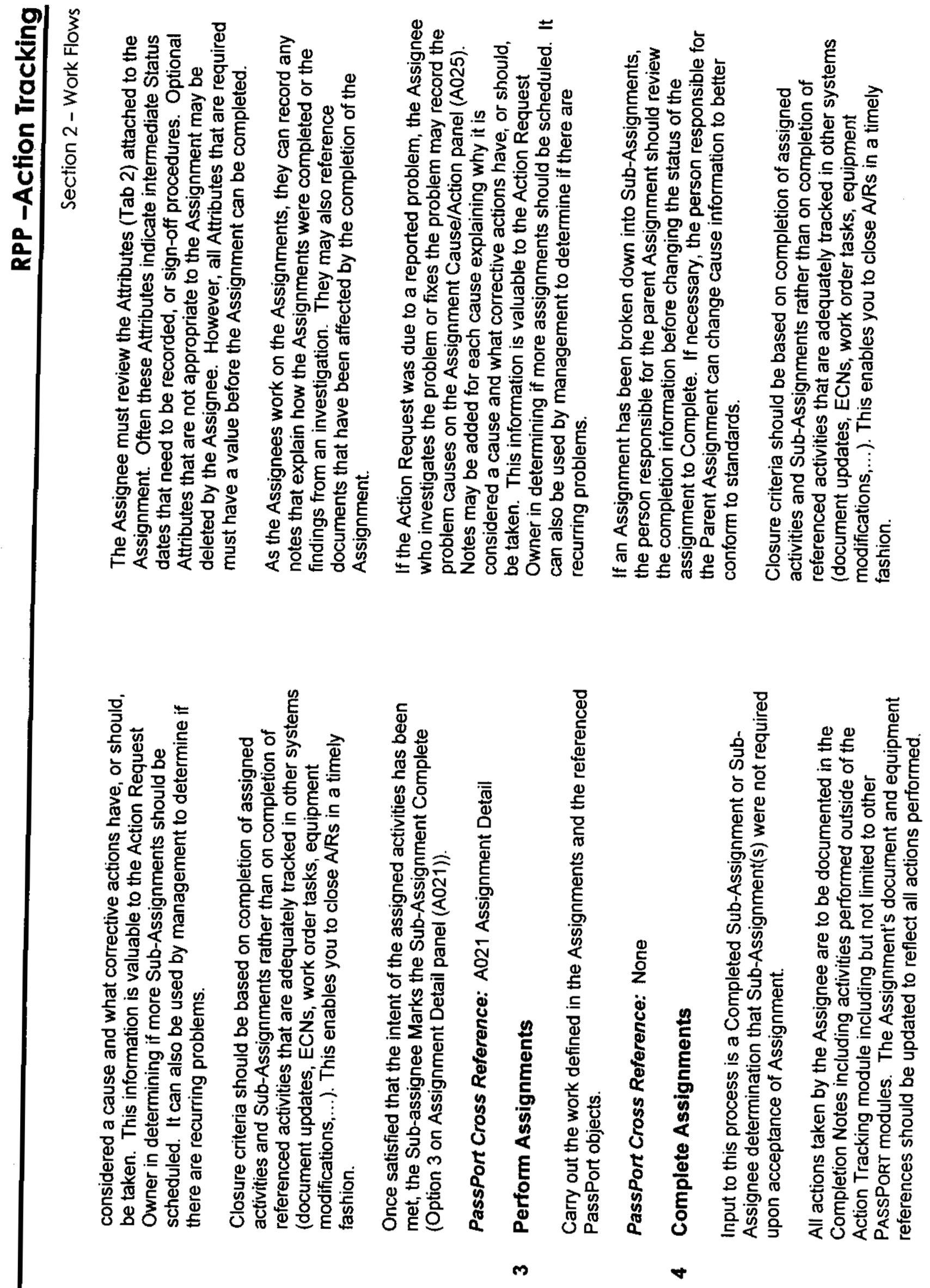

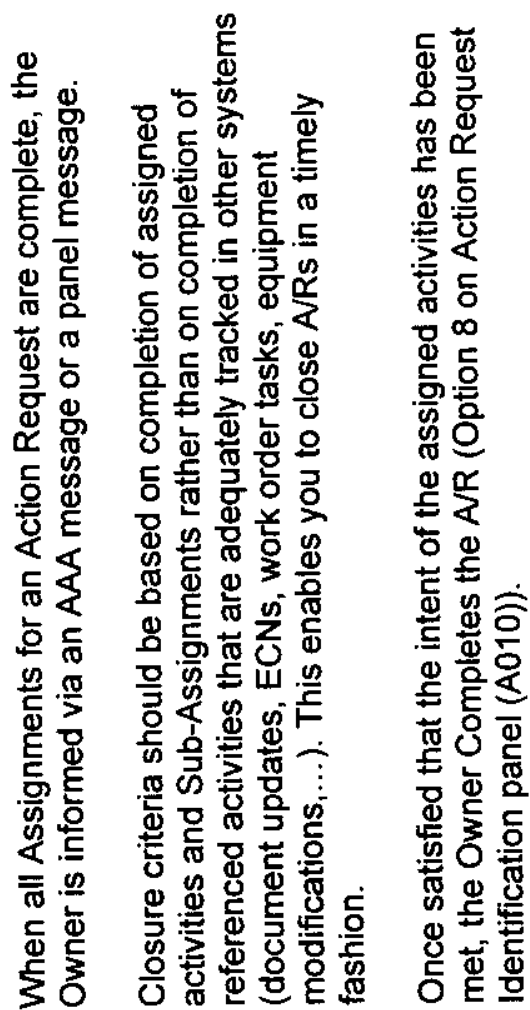

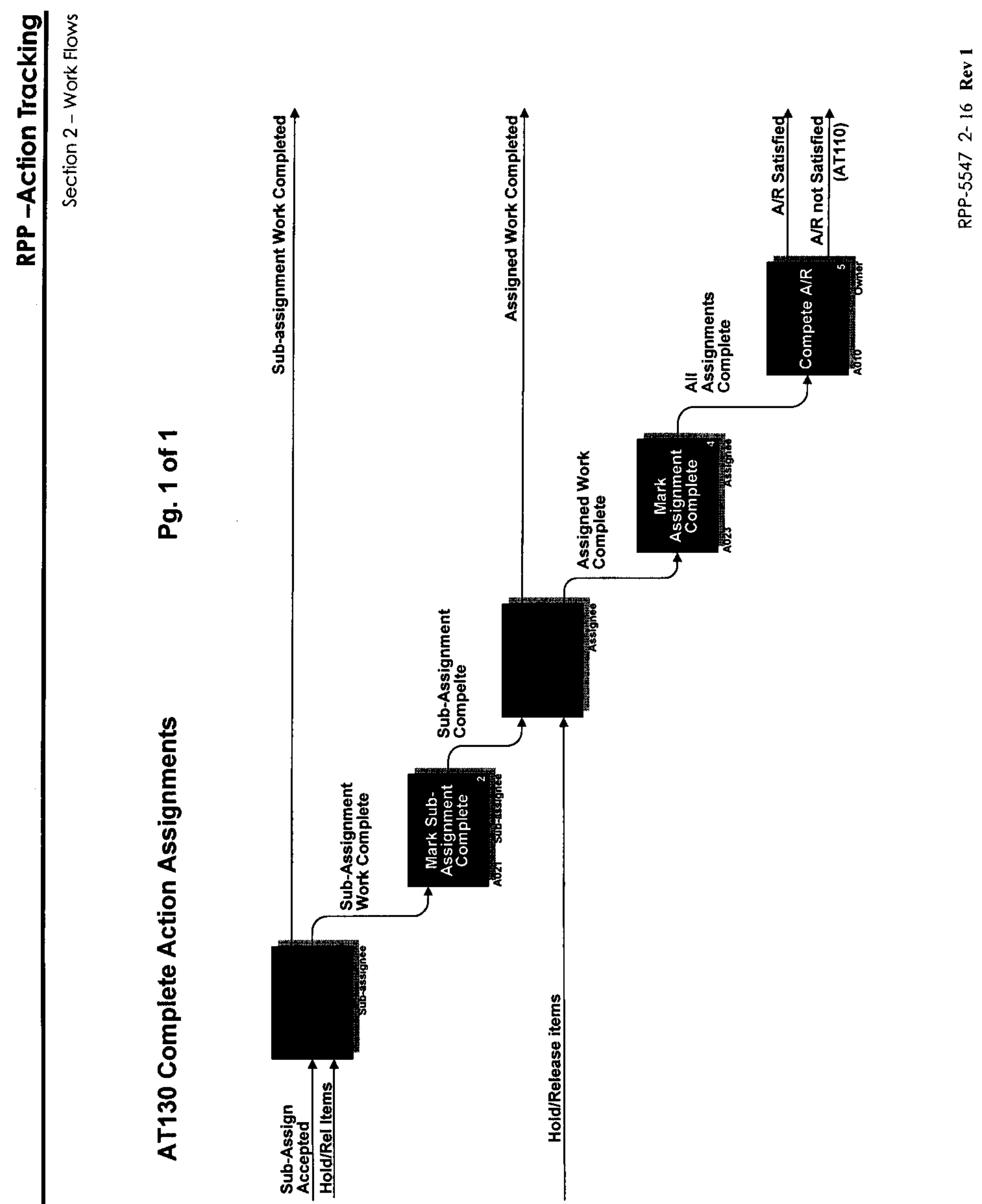

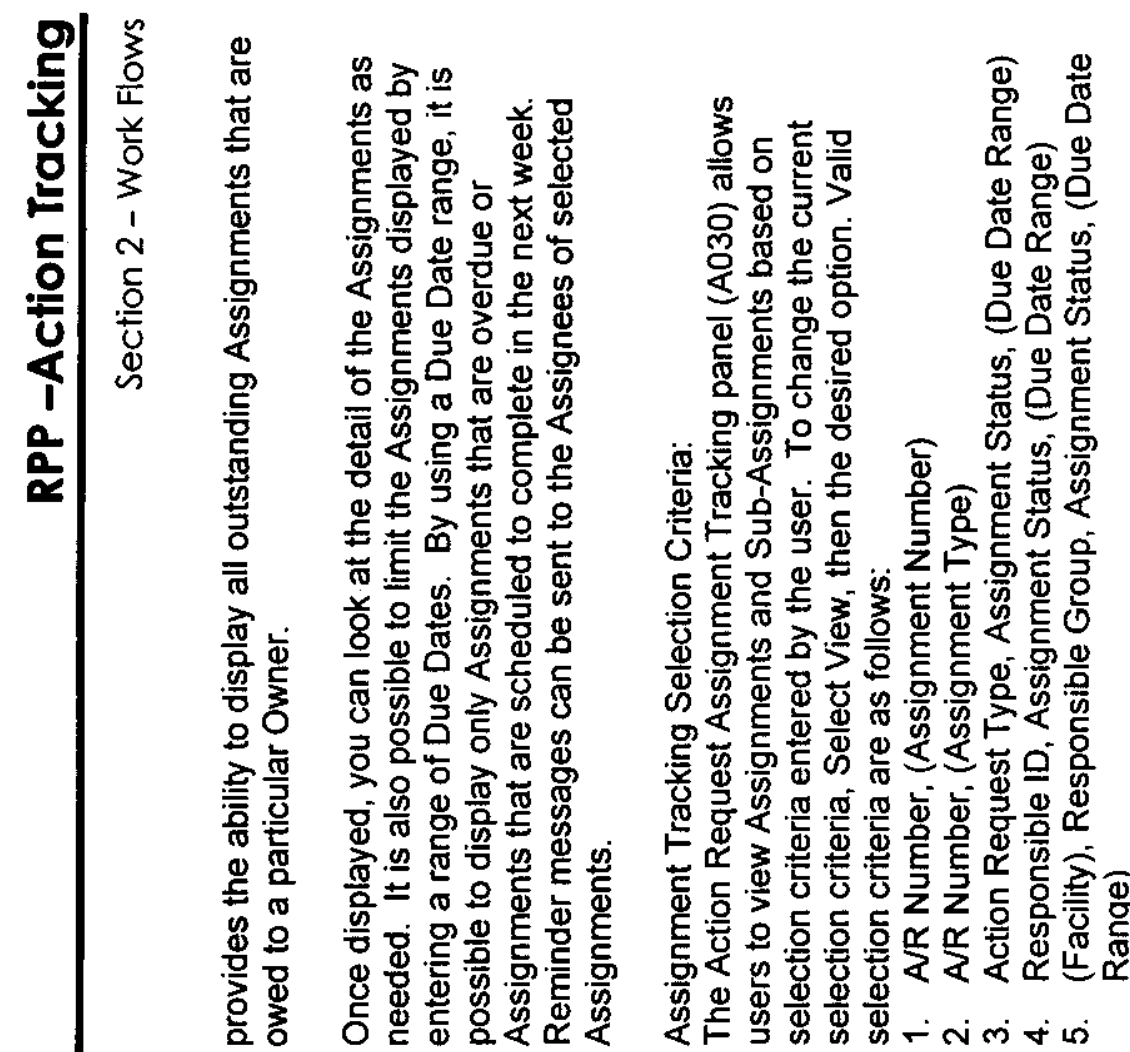

응

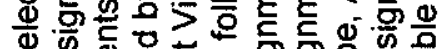

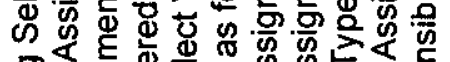

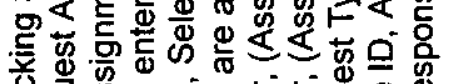

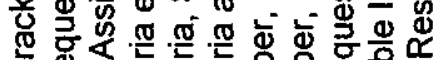

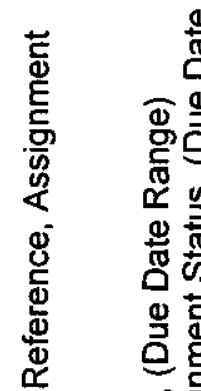

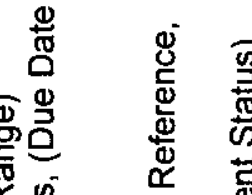

蛋

票票

艺莕焉

章

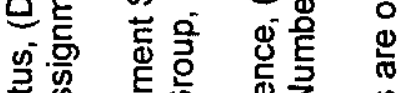

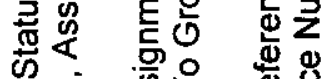

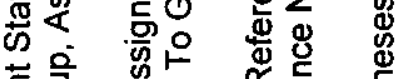

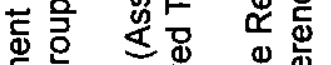

E它

문으

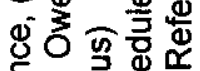

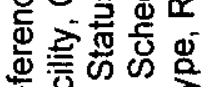

덩通

造

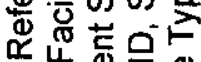

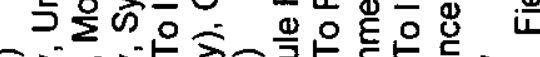

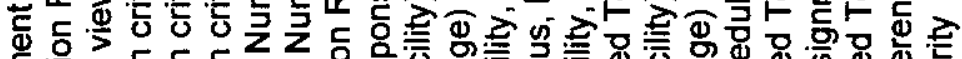

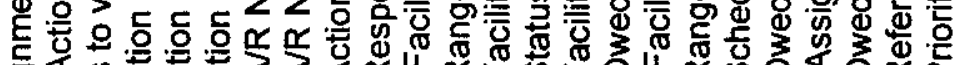

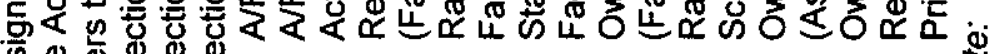

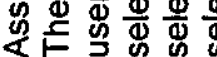

ம
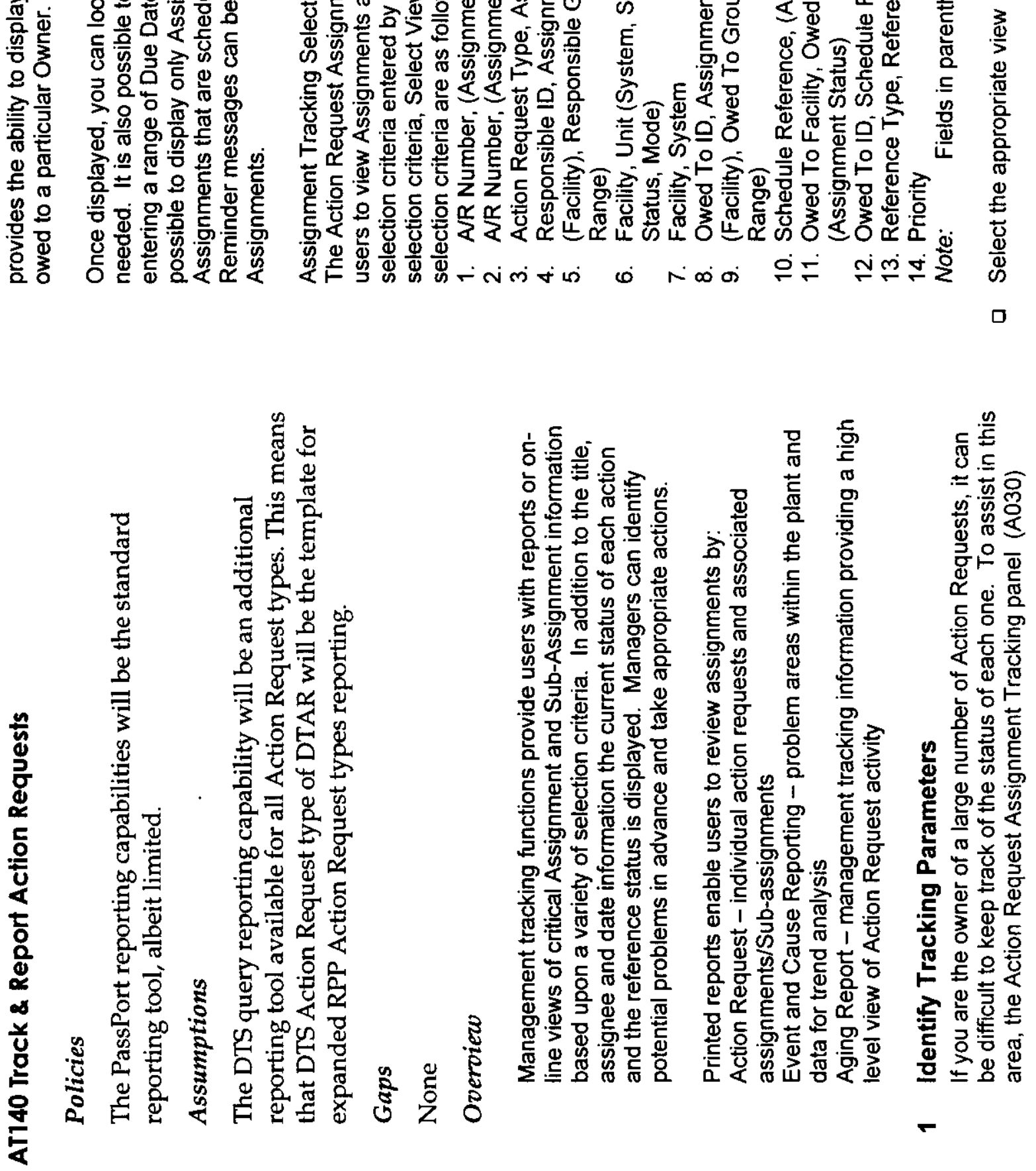


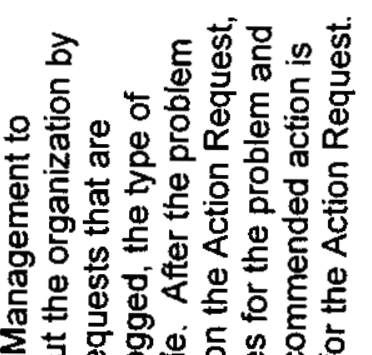

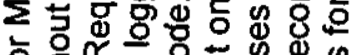

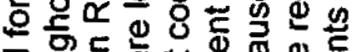

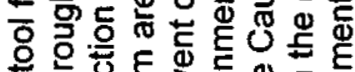

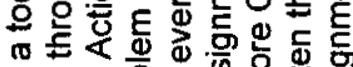

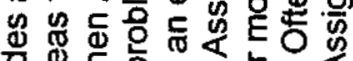

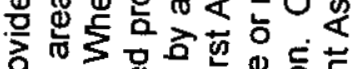

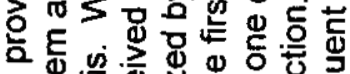

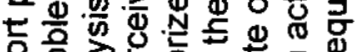

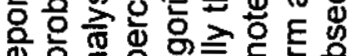

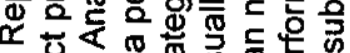

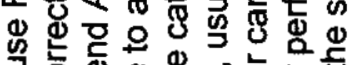

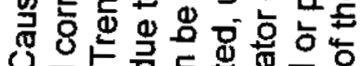

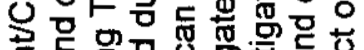

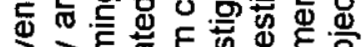

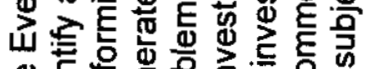

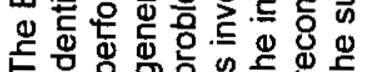

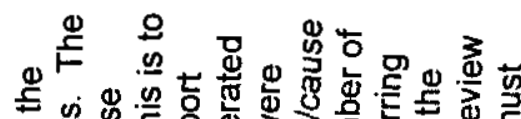

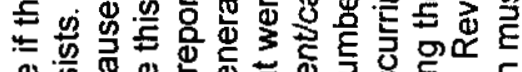

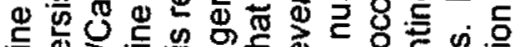

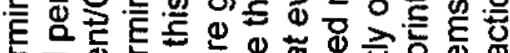

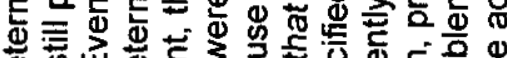

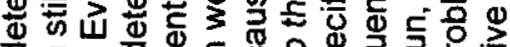

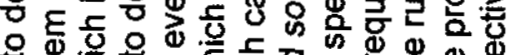

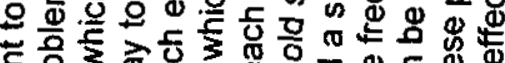

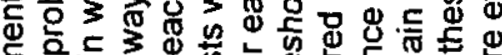

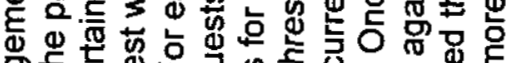

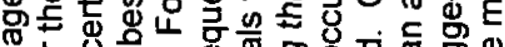
论政 E要

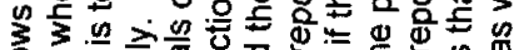

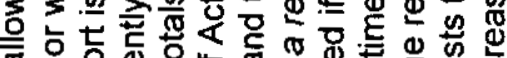

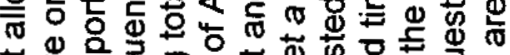

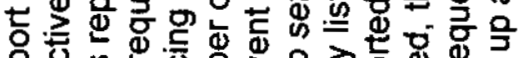

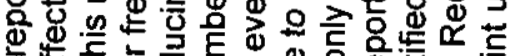

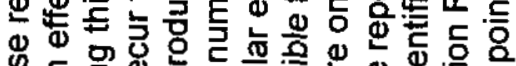

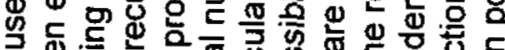

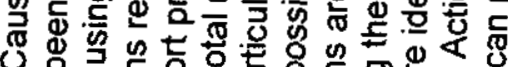

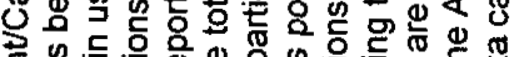

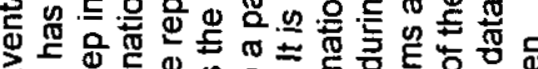
山ᄃ

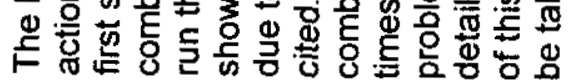

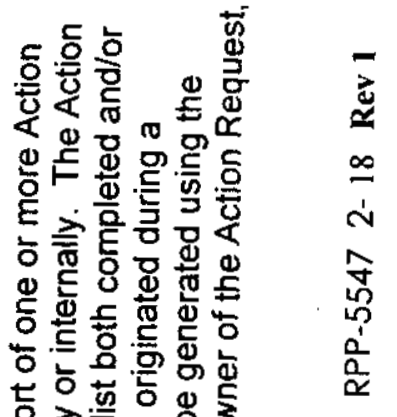

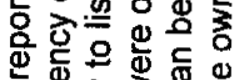

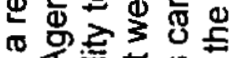

\&

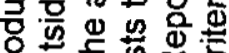

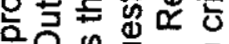
웡 ชิ 흔 응 능

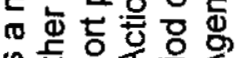
능

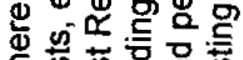

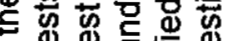

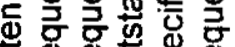

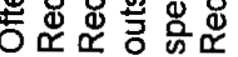

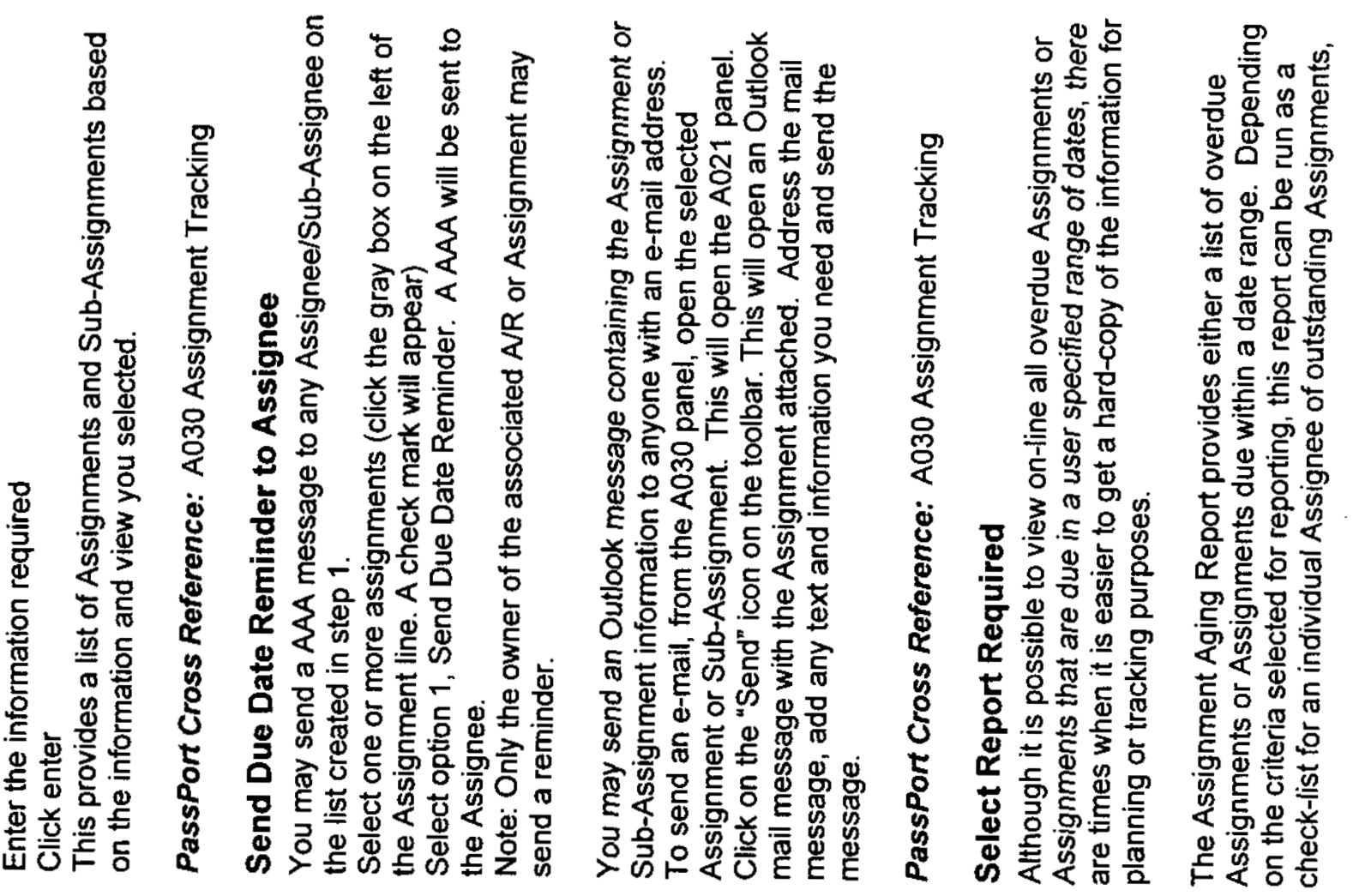




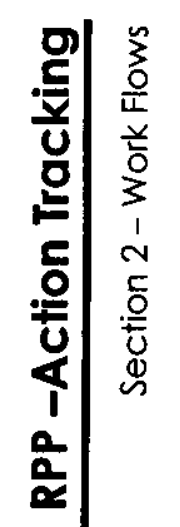

迹

응

边

岁蛋

害

듕

드 능

\& 인

릴

苏

웡

엉 융

뚱ํㅇ

은 용옹

옹

○吅

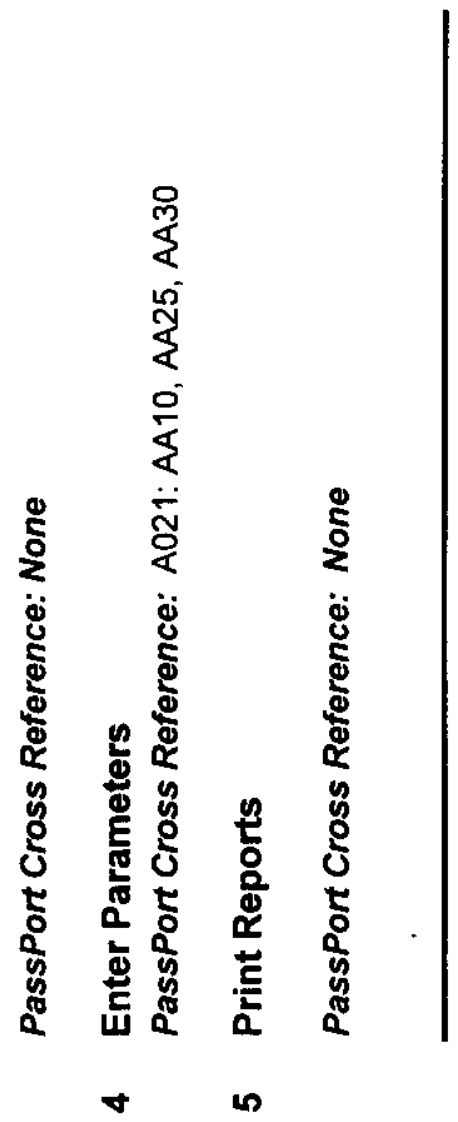


إ:

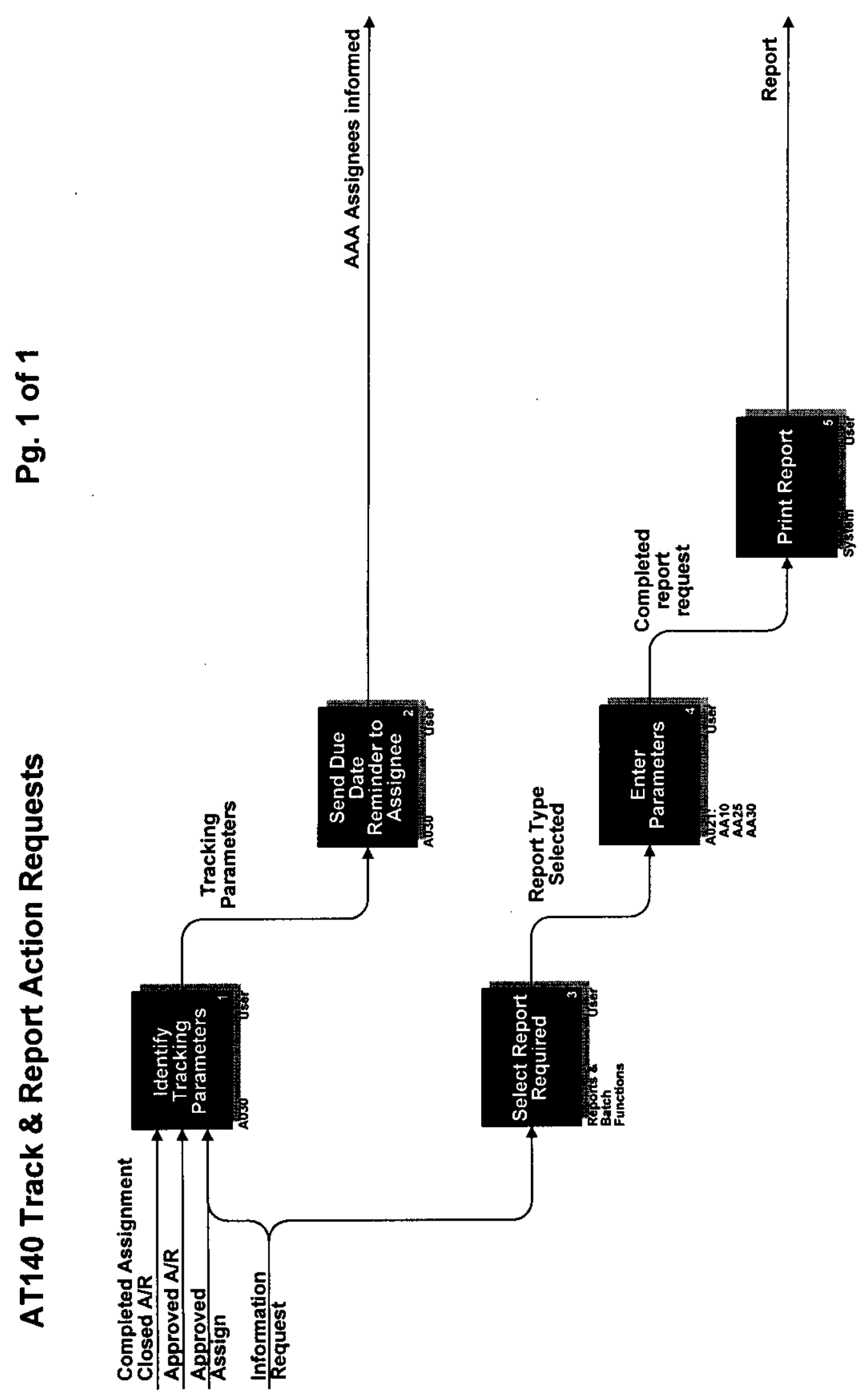

ฉั

오

ஸे

究

$\frac{0}{\alpha}$ 


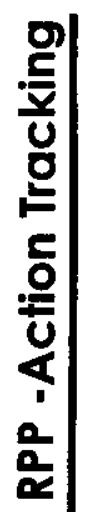

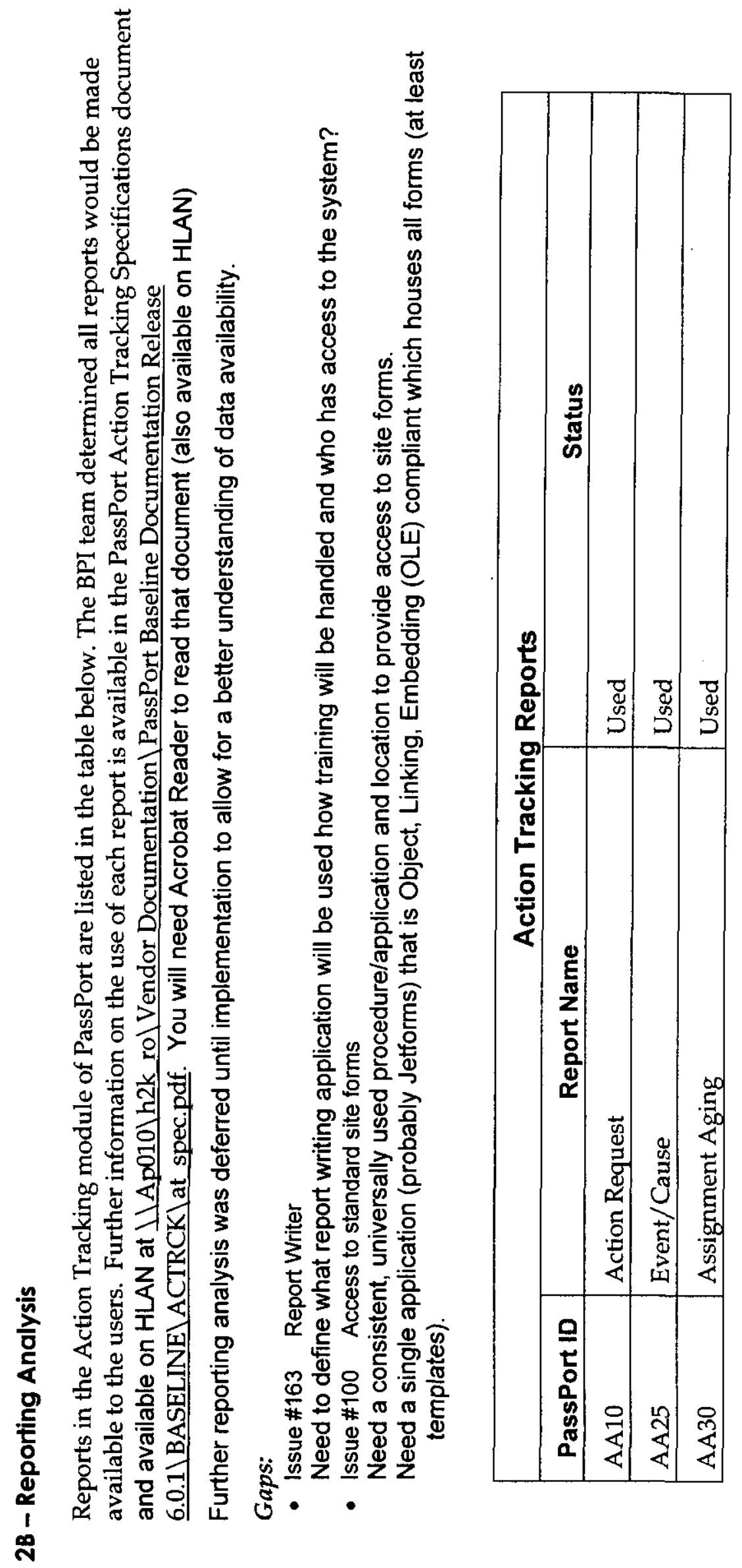

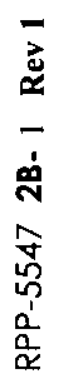




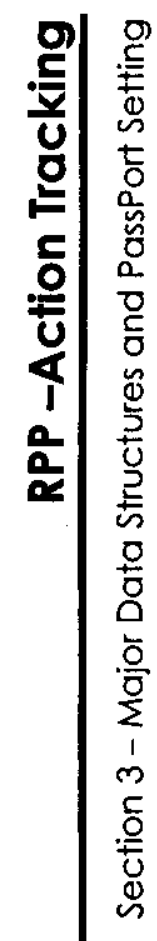

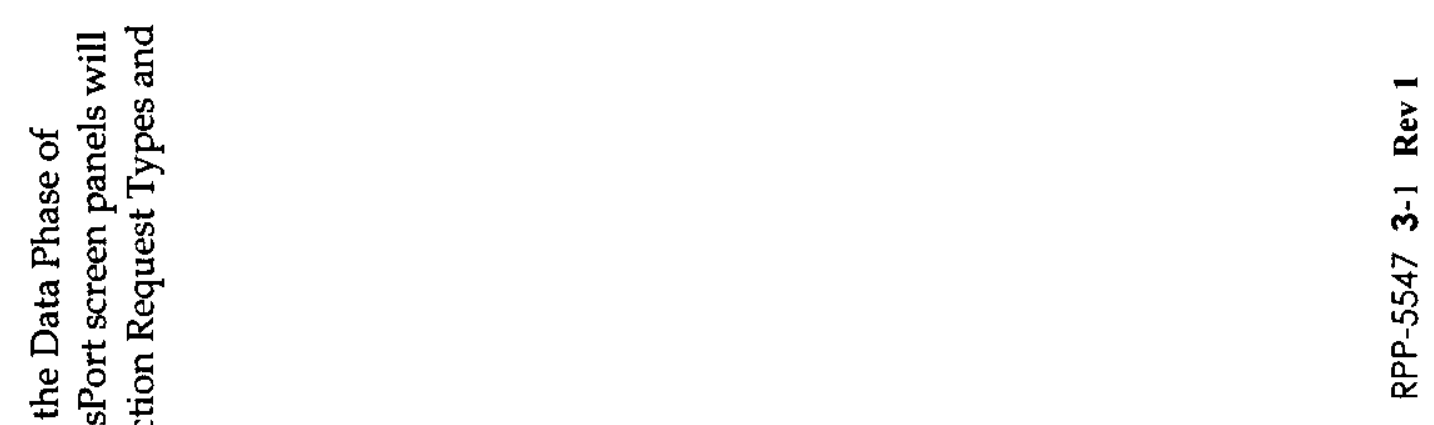

品

a 20

을

도

.

त्ठ

옹 롱응

का है

फ

क ⿻ 丨

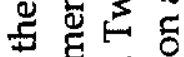

$\Xi \frac{0}{0}$

प تِ

记音

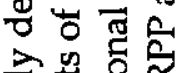

为象. 웅

)

냉

क⿺辶大

氙焉

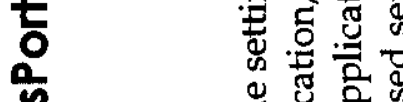

苋高芯

过运

응 穿焉

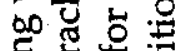

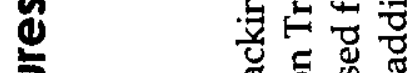

5

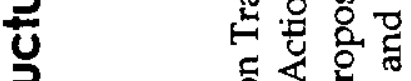

은

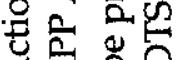

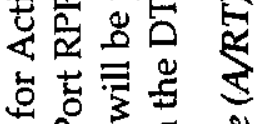

응

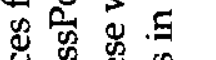

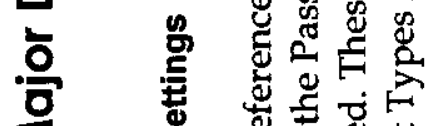

它范

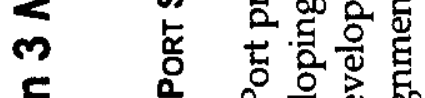

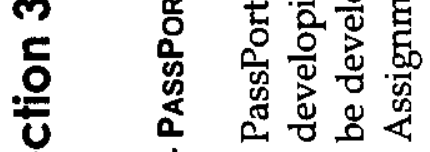

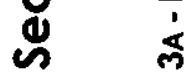

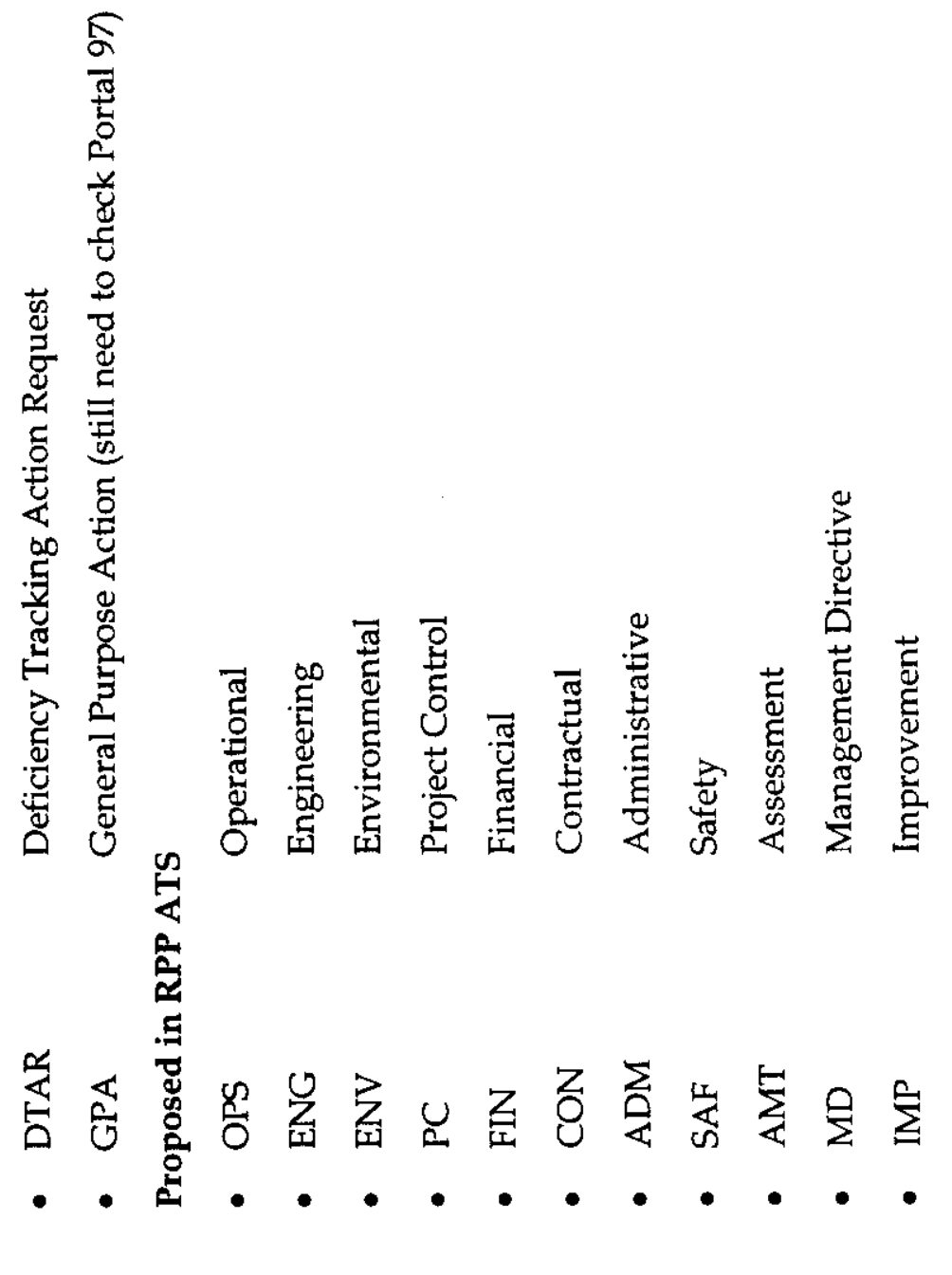




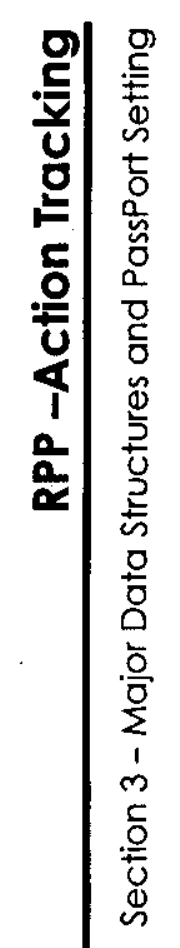

$\vec{a}$
$\tilde{a}$
$\tilde{m}$
$\hat{y}$
$\stackrel{0}{0}$
$\frac{1}{\alpha}$
$\frac{1}{\alpha}$

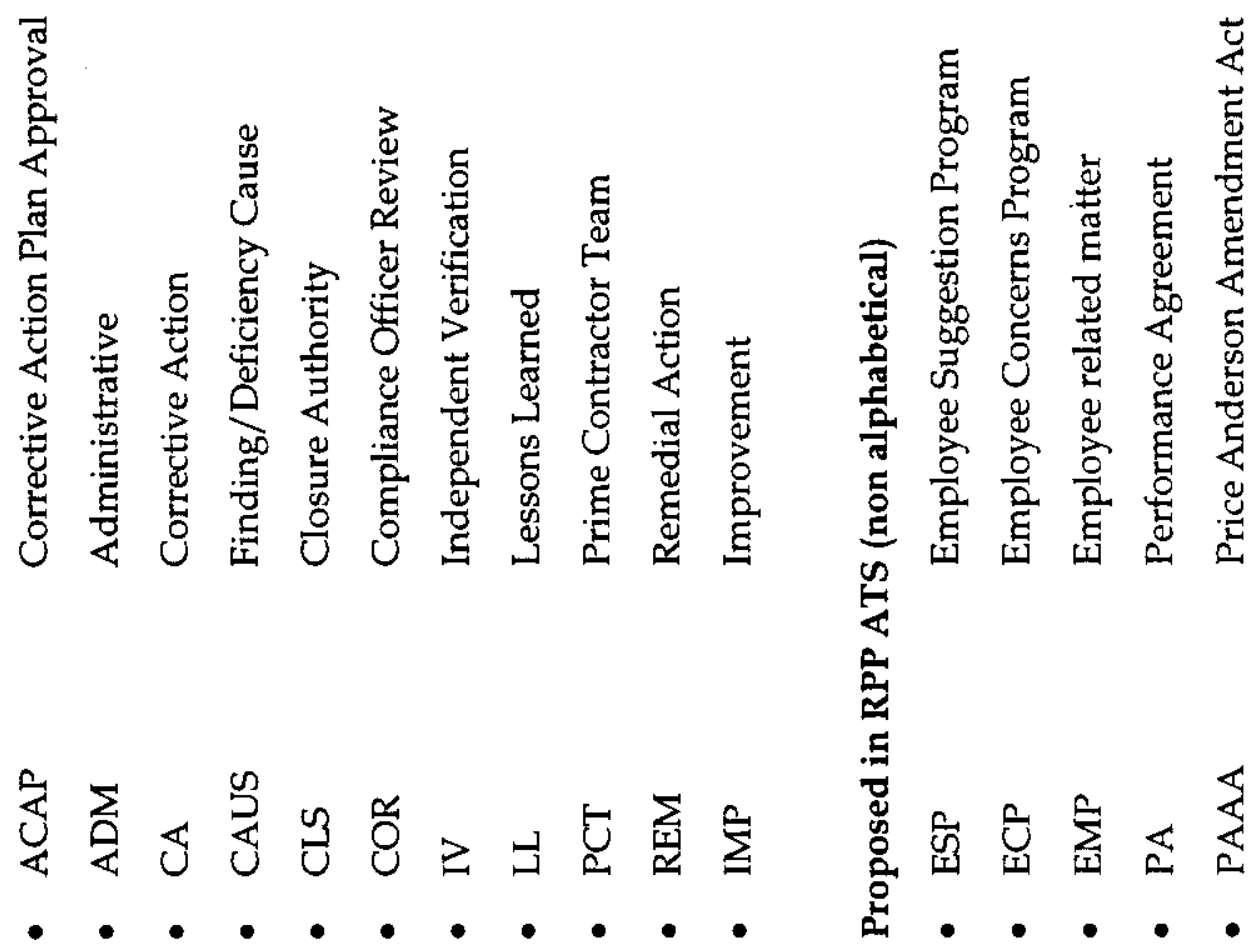




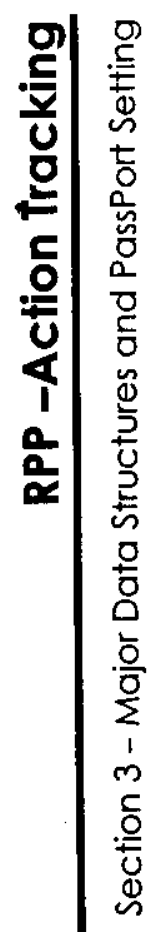

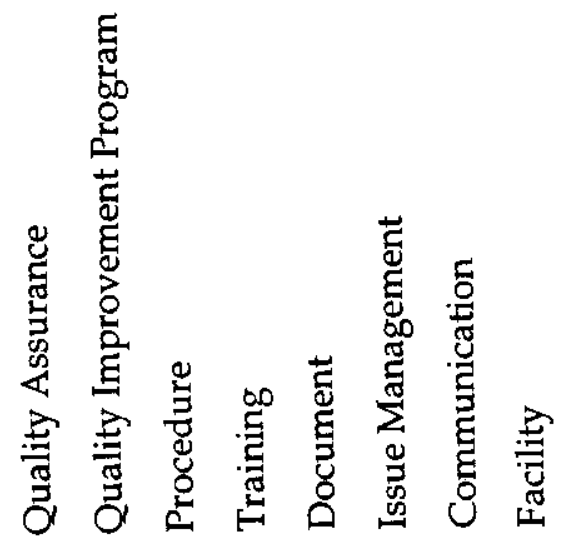

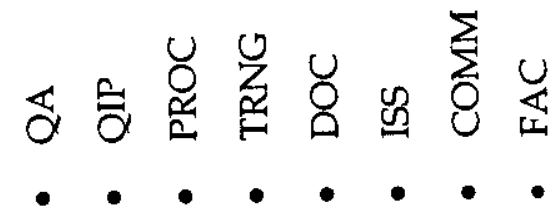




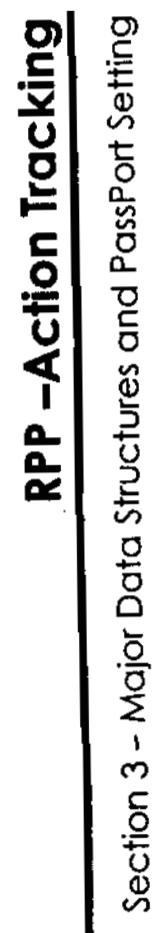

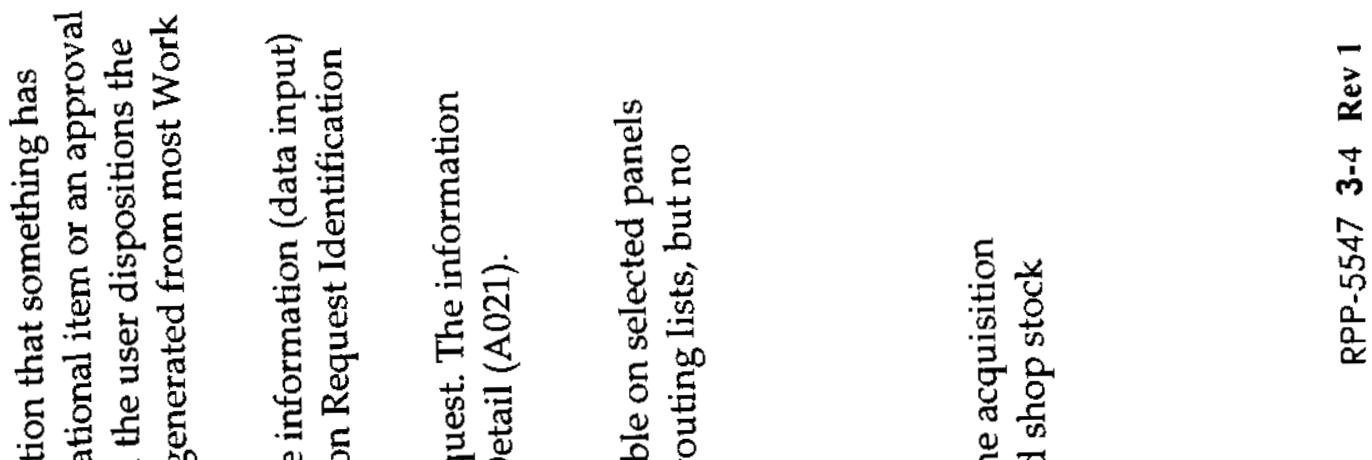

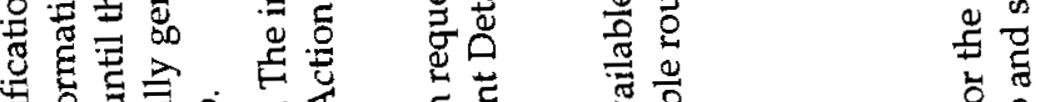

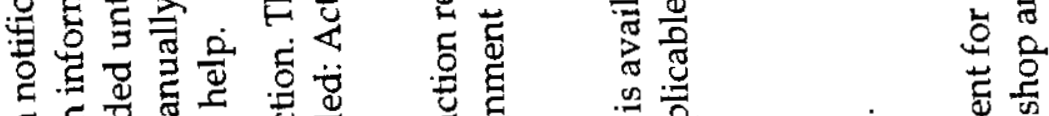

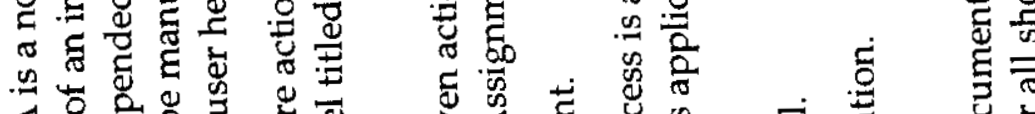

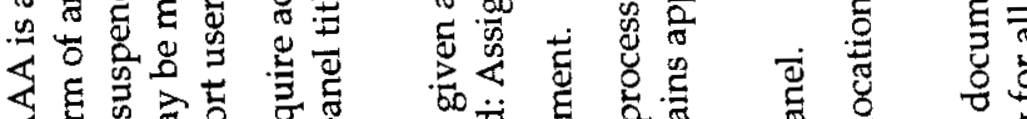

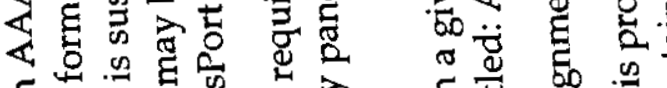

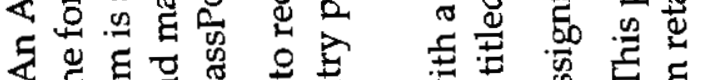

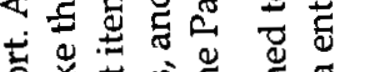

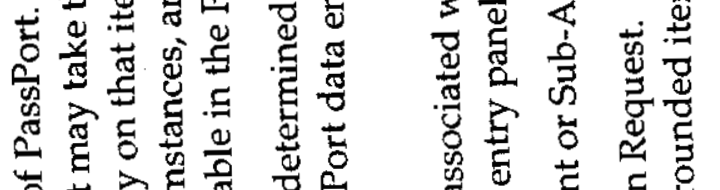

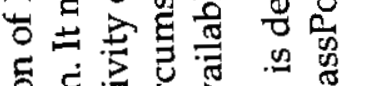

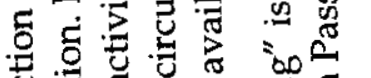

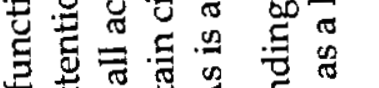

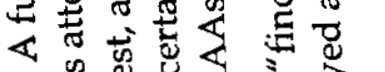
कृ

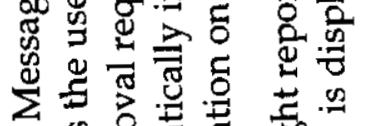

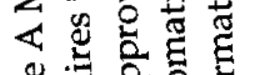

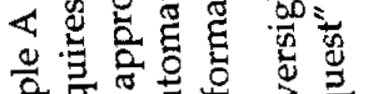

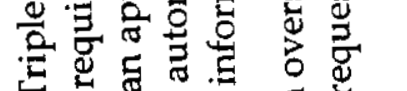

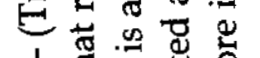

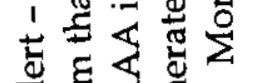

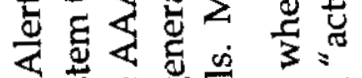

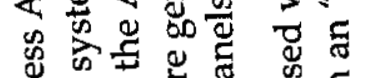

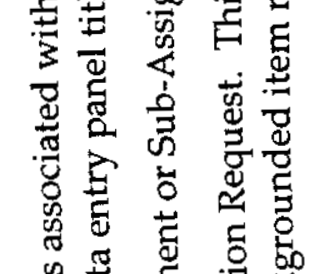
要 总泀

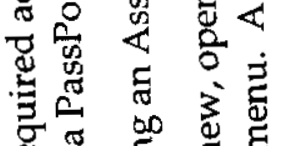
焉

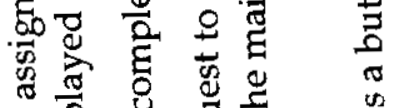
त $\prod_{\infty}^{\infty}$

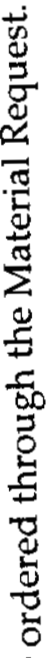

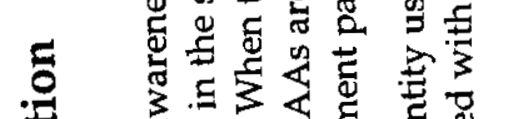
ᄀ.

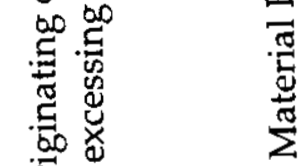

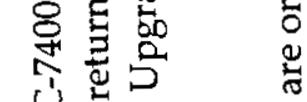
פ 它焉若

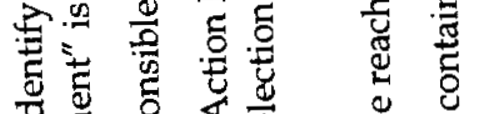

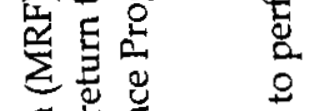
छे \&

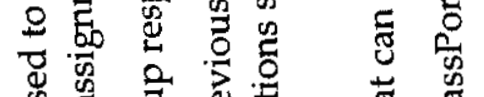

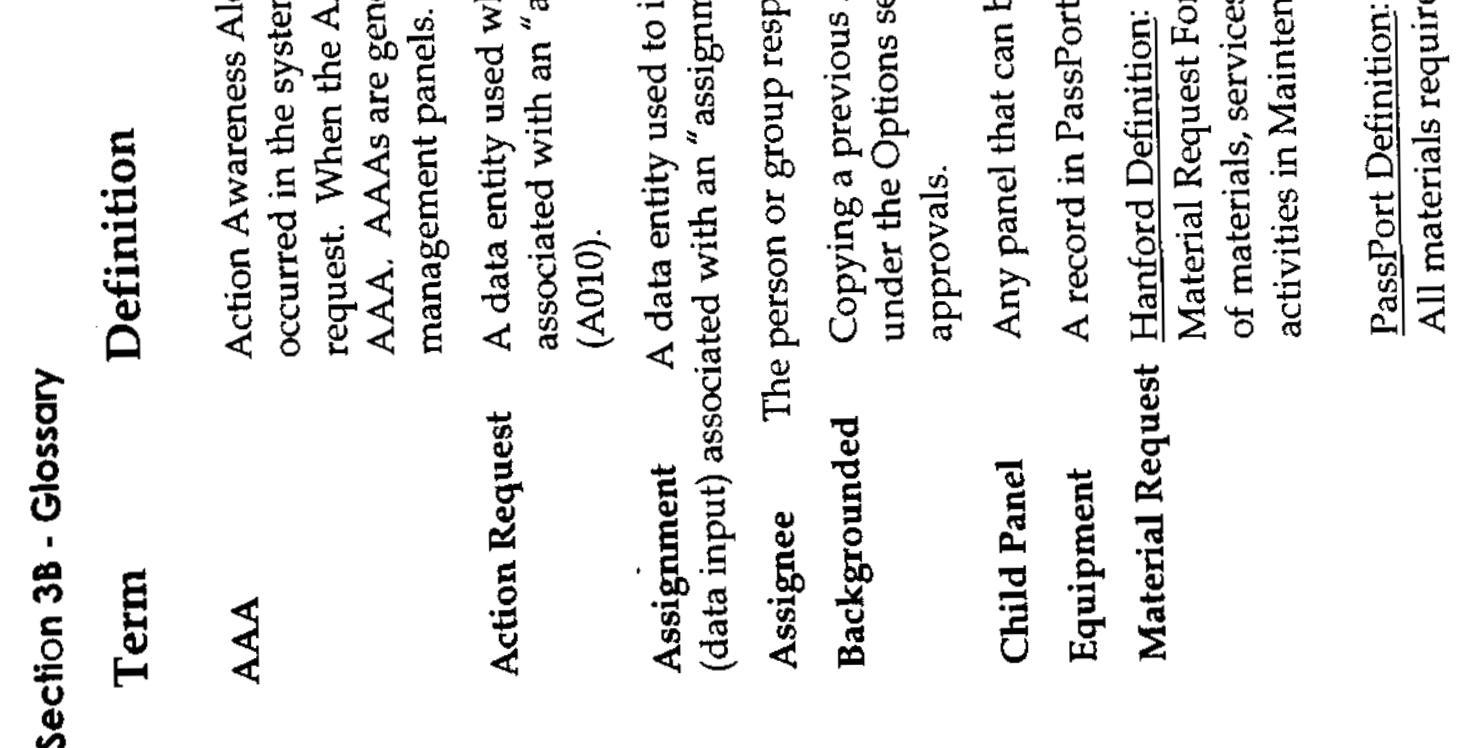

$\frac{\sqrt{\frac{5}{2}}}{3}$ 


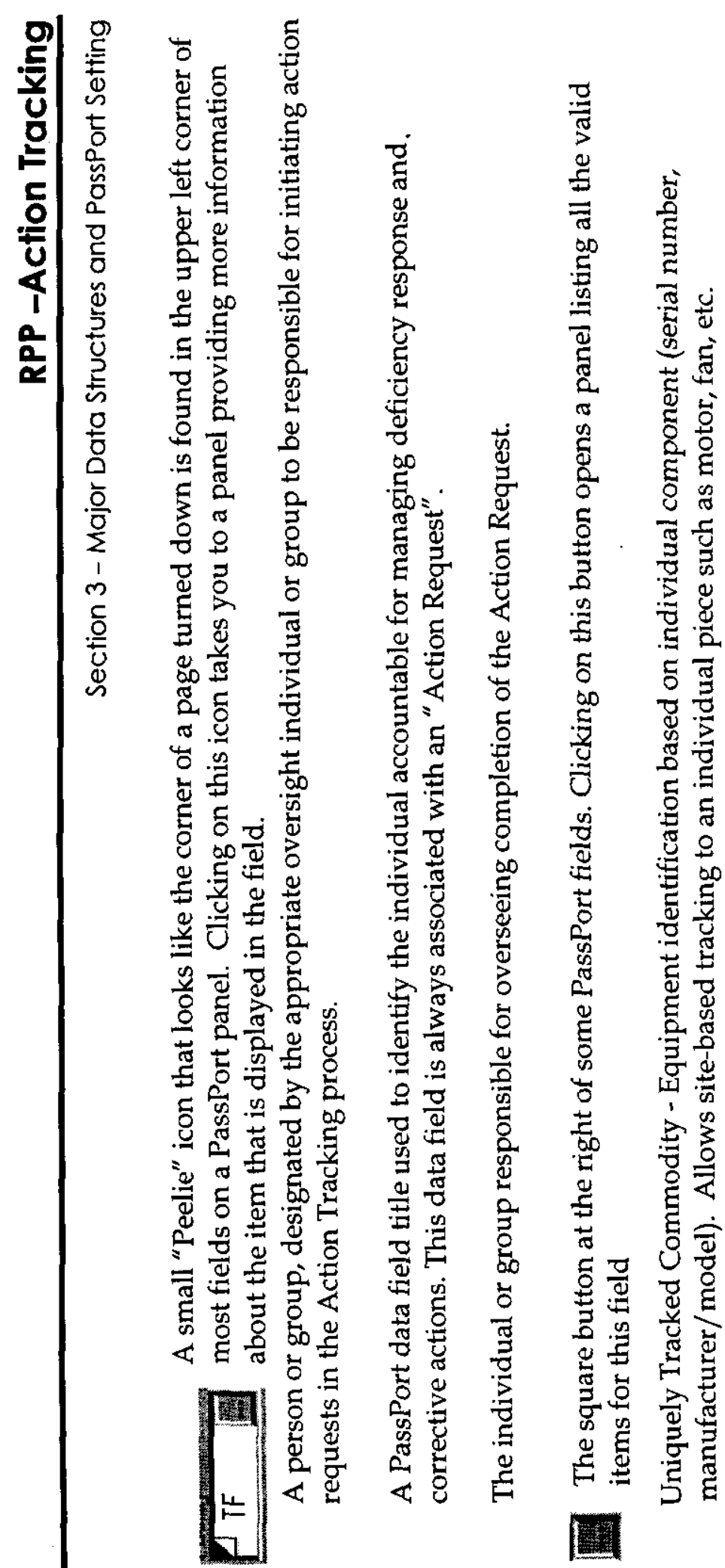

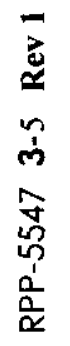

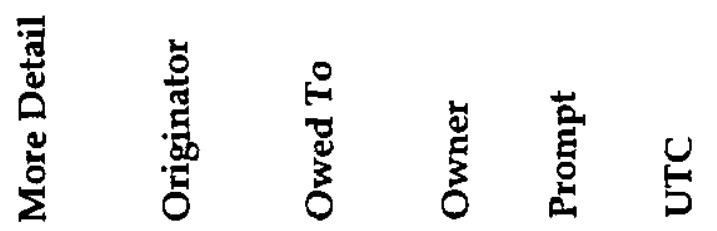




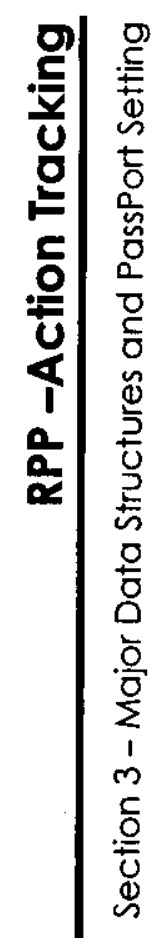

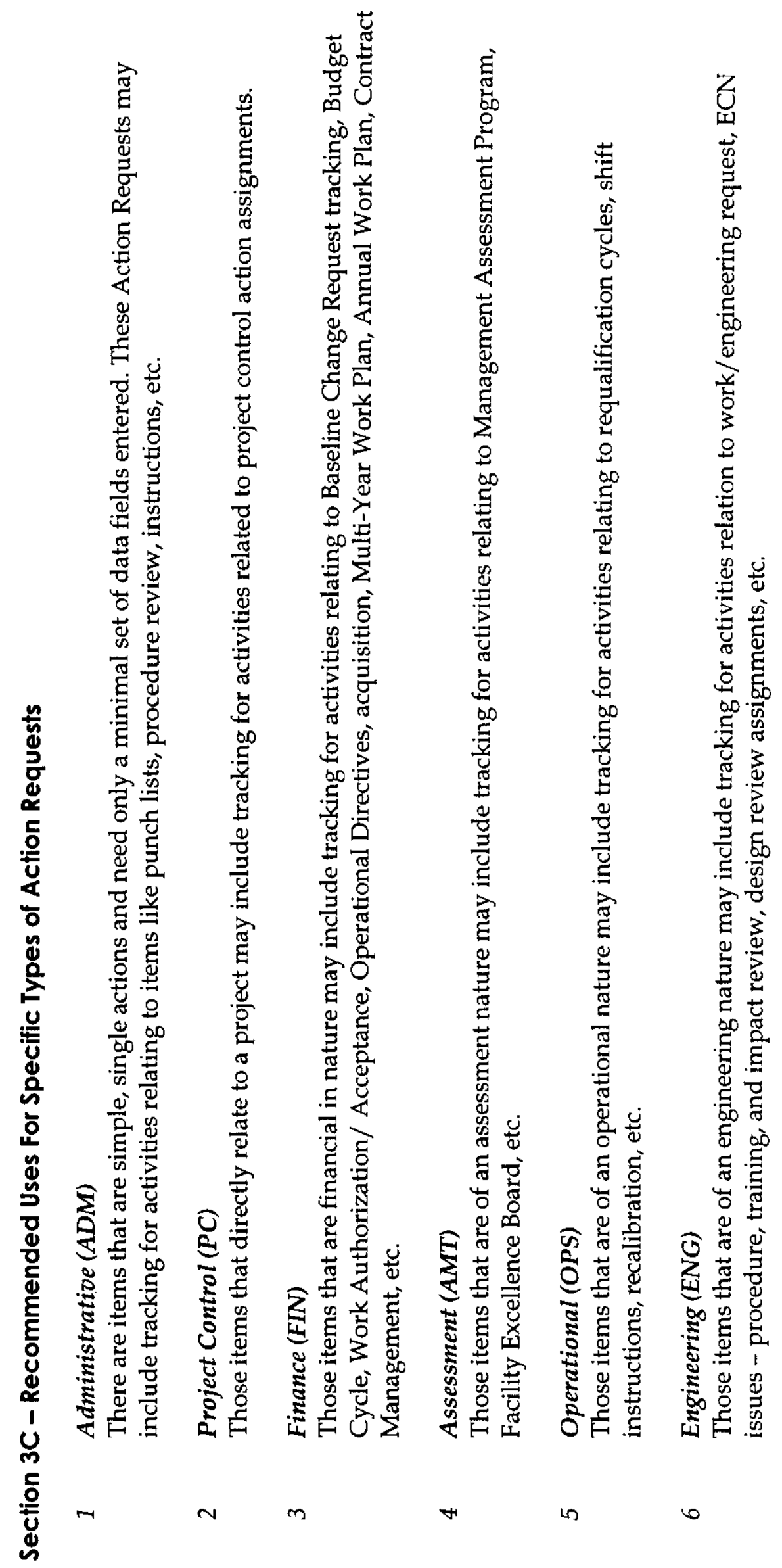




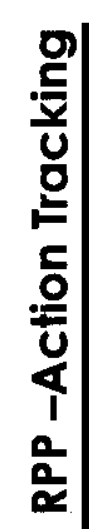
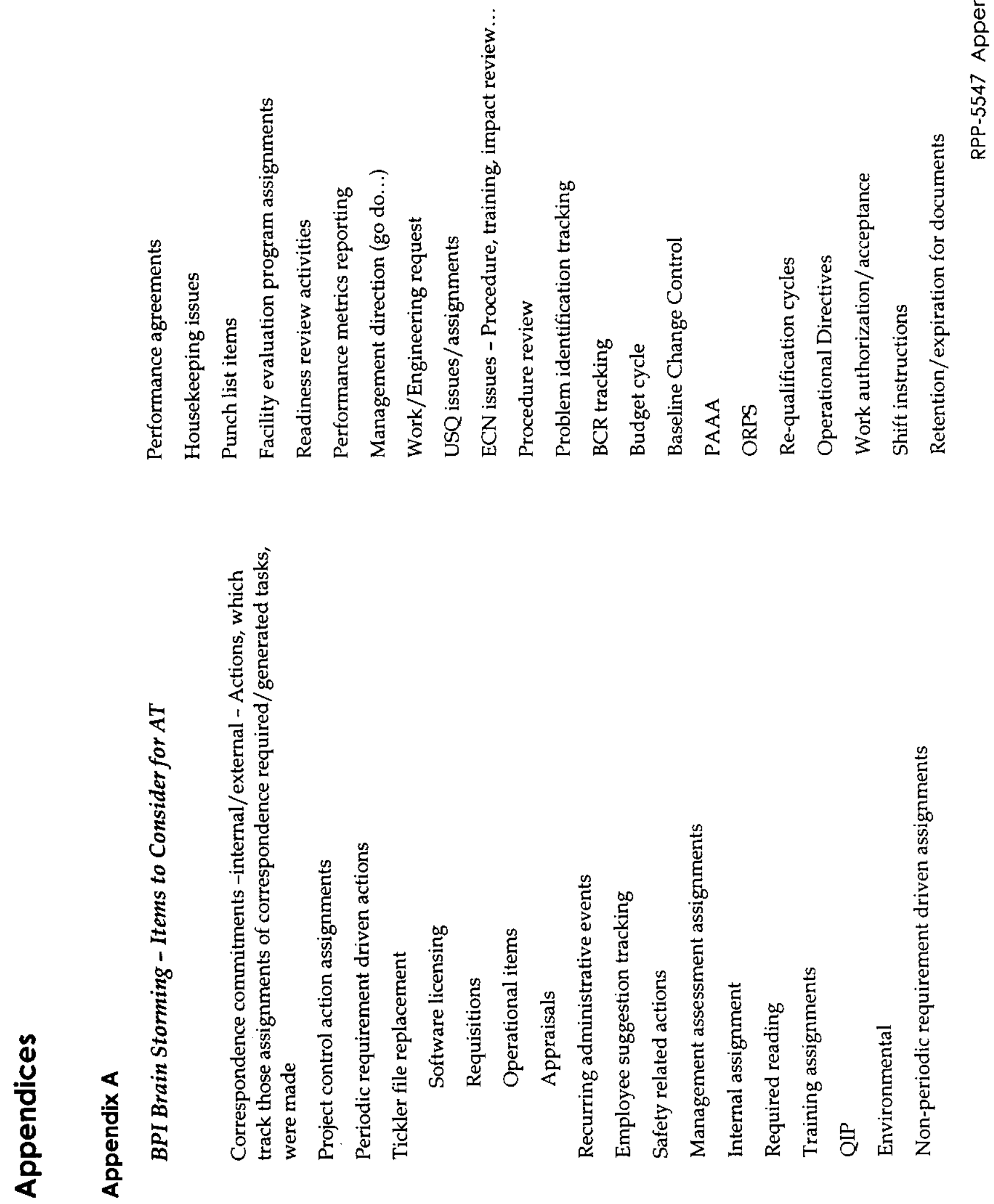

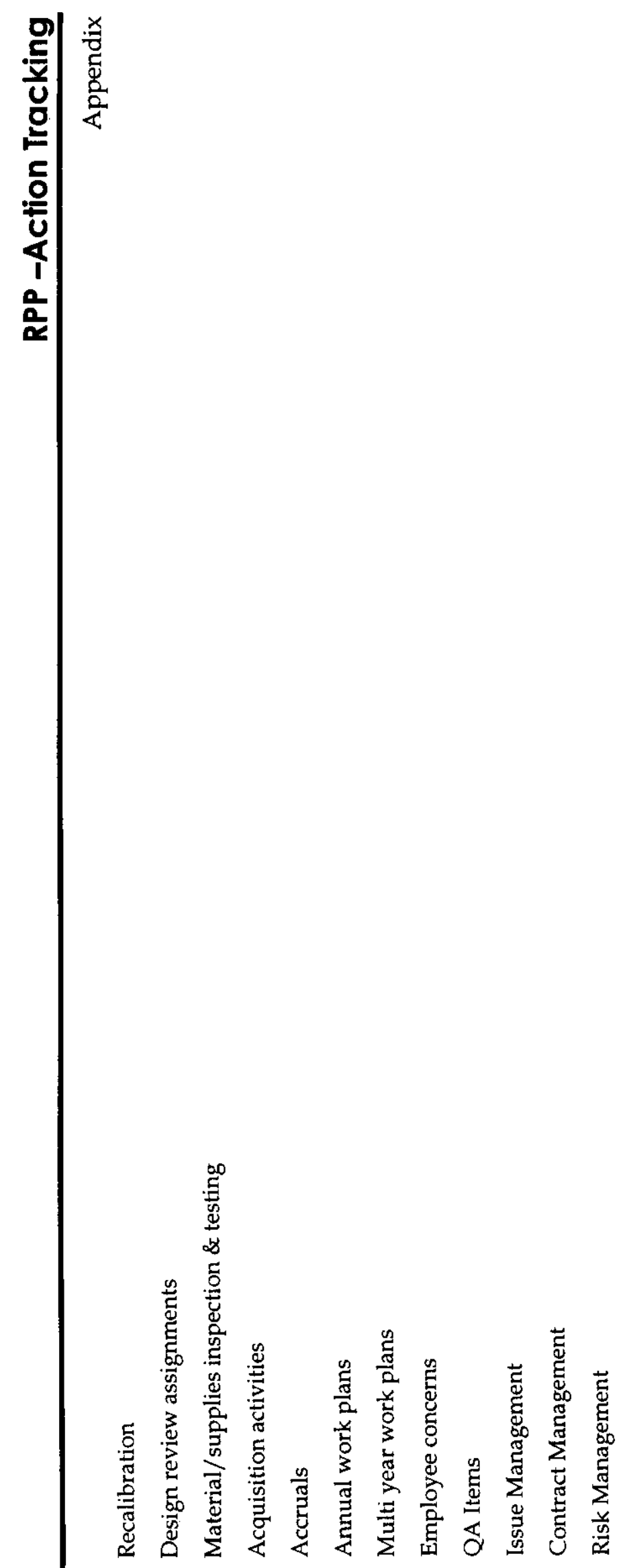

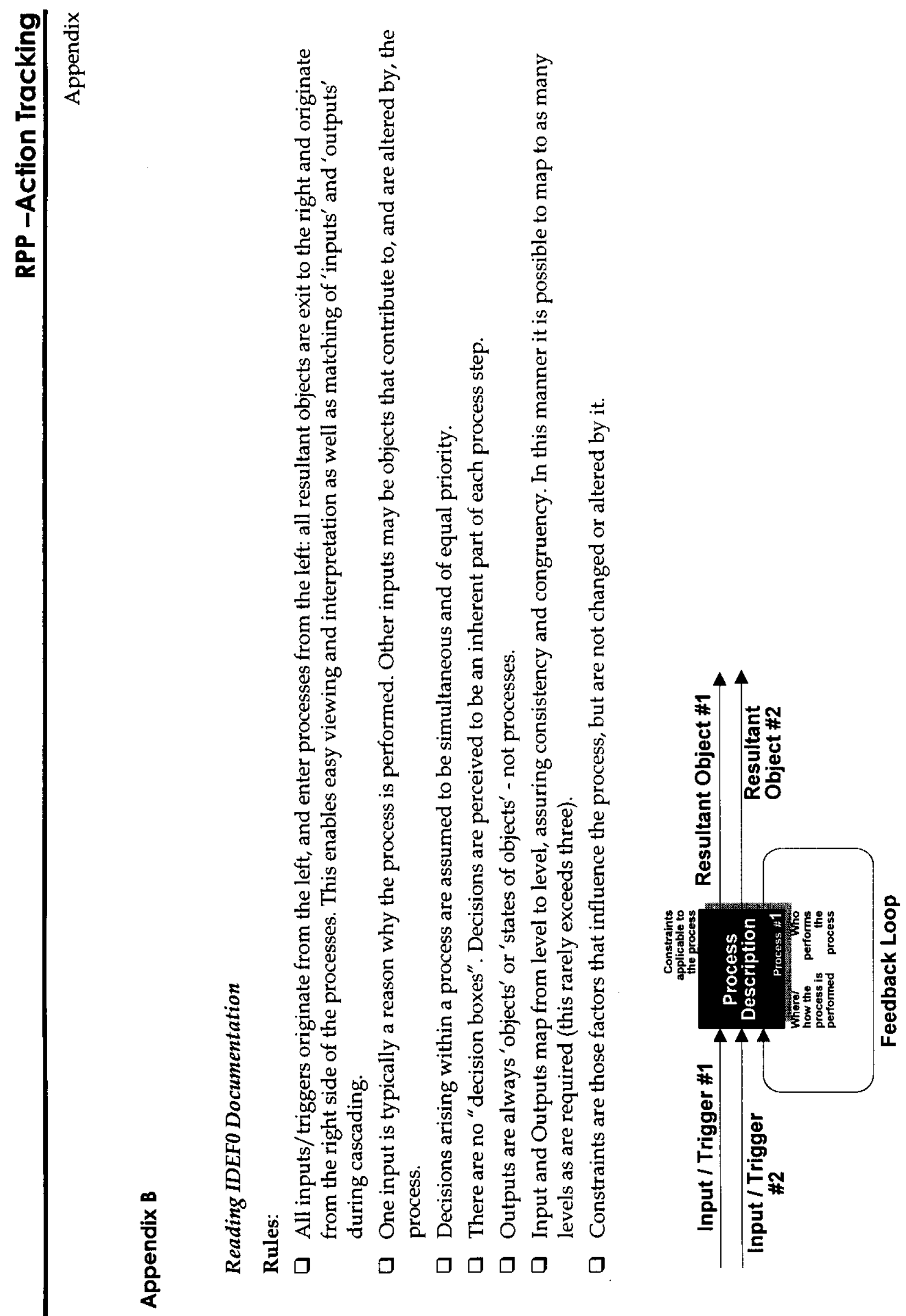

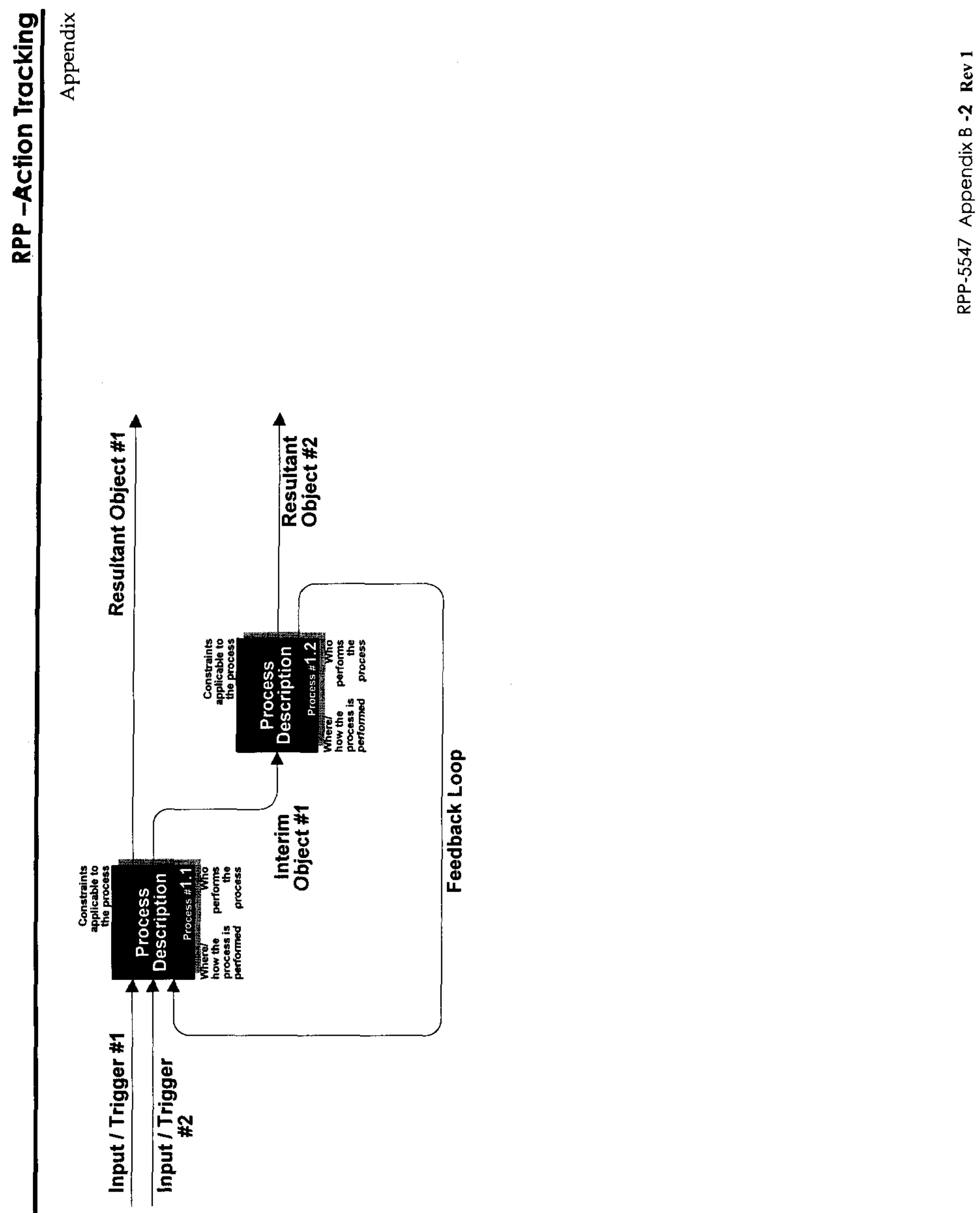


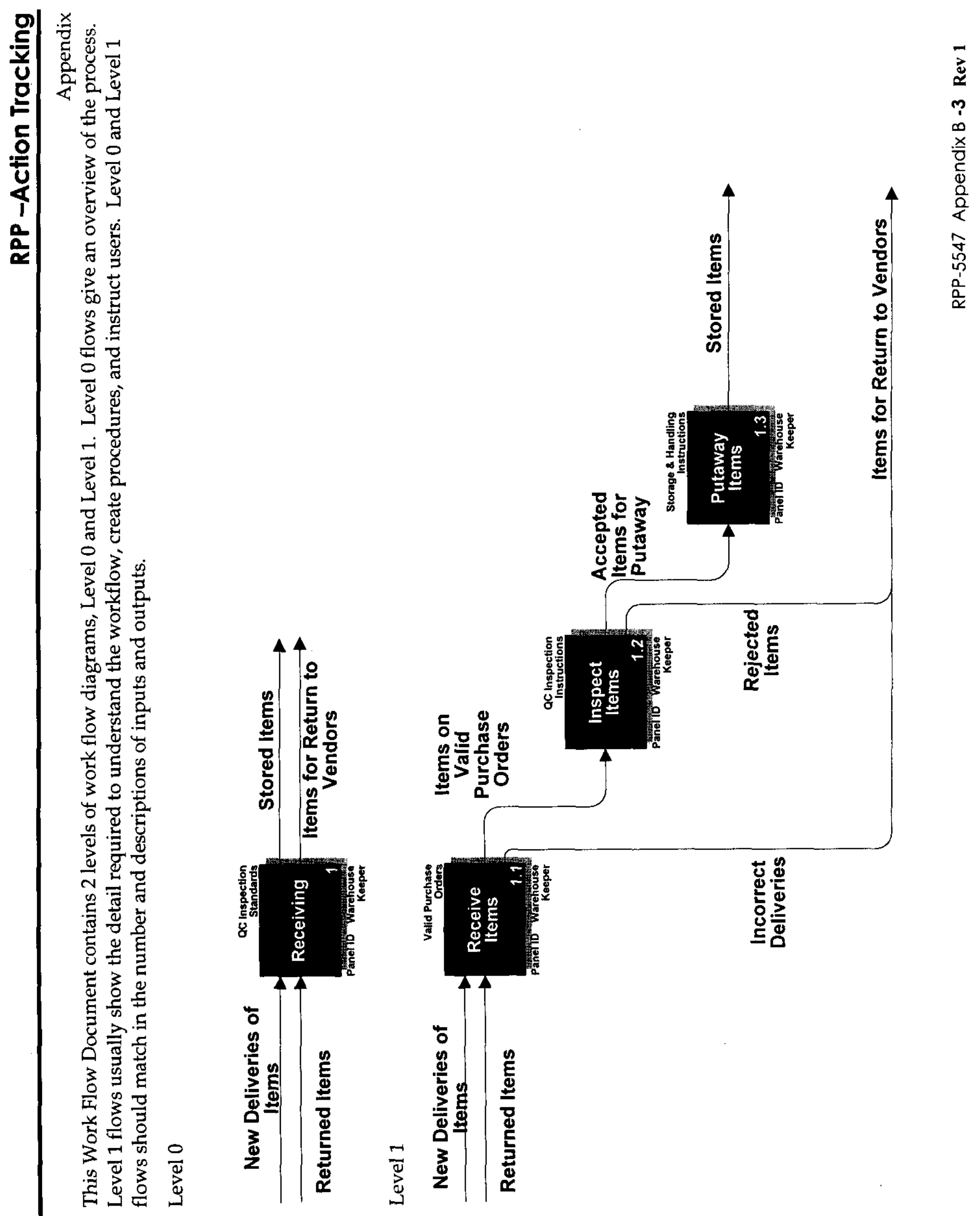

